\title{
A Survey of the Preparation, Purity, and Availability of Silanes
}

\section{A Subcontract Report}

James H. Lorenz

December 1983

Prepared under Subcontract No. CL-3-00321-01

Draft Prepared under Task No. 1479.10 WPA No. 425

SERI Technical Monitor: Amir Mikhail

Solar Energy Research Institute

A Division of Midwest Researon Institute

1617 Cole Boulevard

Golden, Colorado 80401

Prepared for the

U.S. Department of Energy

Contract No. DE-AC02-83CH10093 
SEP

STR -2092

PREFACE

This report was prepared by James $\mathrm{H}$. Lorenz under Consultant Agreement No. CL-3-00321-01, Prime Contract No. EG-77-C-01-4042, for the Solar Energy Research Institute. The objective of this work was to provide researchers in the field of amorphous silicon with up-to-date information on silane and disilane.

Users of silanes in general should find this report of interest for its surveys of the preparation and purification procedures of silanes and for the summaries of the industrial aspects of processes used commercially in the United States and Japan. Comments on the purity of available silanes and its impact on photovoltaic device performance are presented. Information supplied by silane producers as well as the purity analysis data supplied by Dr. Reed Corderman of Brookhaven National Laboratory is gratefully acknowledged. The constructive reviews by $\mathrm{Dr}$. Corderman and $\mathrm{Dr}$. Ralph Lutwack of the Jet Propulsion Laboratory were very helpful.

Approved for

SOLAR ENERGY RESEARCH INSTITUTE

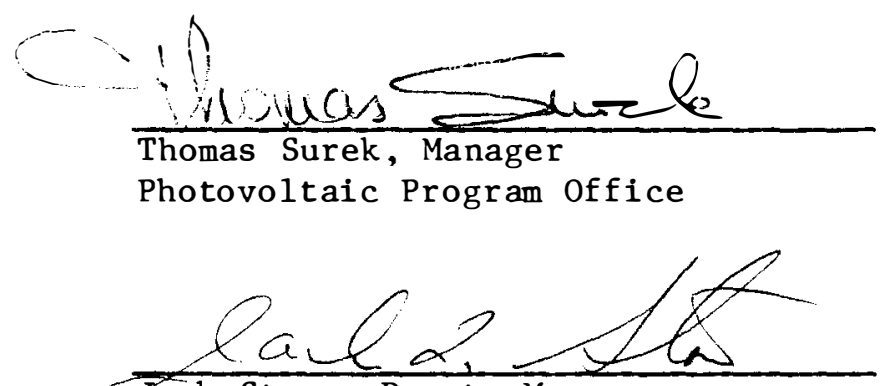

Jack Stone, Deputy Manager

Solar Electric Conversion Research Division

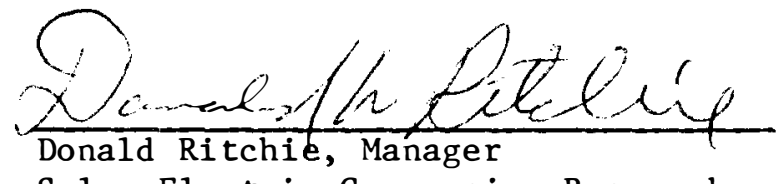

Solar Electric Conversion Research Division

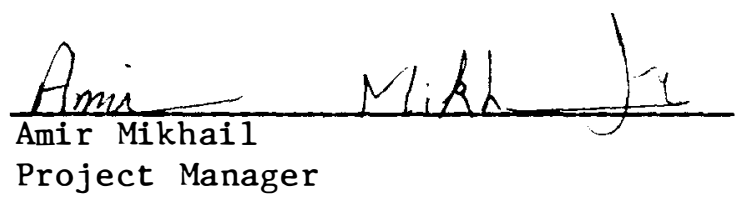

Project Manager

i 



\section{SUMMARY}

This report presents data on the current silane market. Published and public information on 22 preparative methods for monosilane and higher silanes are reviewed. Twenty-four referenced purification methods are presented and discussed. Sources for the contaminants in silanes are identified. The effects of impurities in silane on solar cell performance are included, and data from current suppliers of silane are tabulated, including processes used, prices, and available grades. Typical and actual analyses of commercial silanes are also given.

The silane process developed by Union Carbide Corporation under the DOE/JPL Flat-Plate Solar Array Project is summarized, including the purification steps. A section on the status of silanes in Japan is also included. 
TABLE OF CONTENTS

Page

1.0 Int roduction.................................... 1

2.0 Silane and Disilane in the United States................... 3

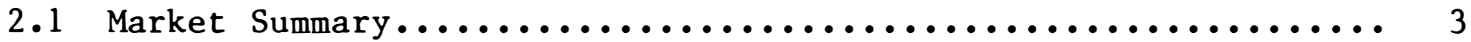

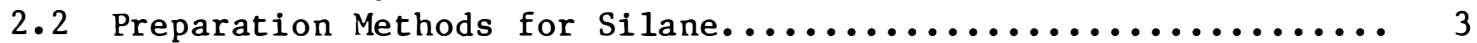

2.3 Preparation Methods for Higher Silanes.................... 7

2.4 Possible Impurities and Impurity Levels in Commercial

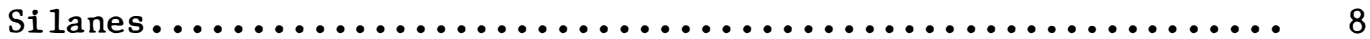

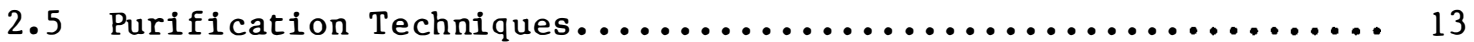

2.6 Commercial Availability ........................... 18

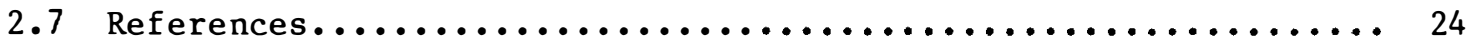

3.0 Review of the JPL/UCC Contract--Silane for Polysilicon Project..... 29

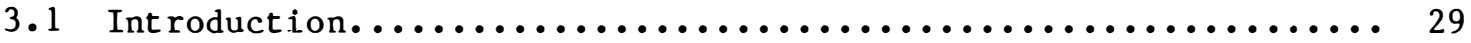

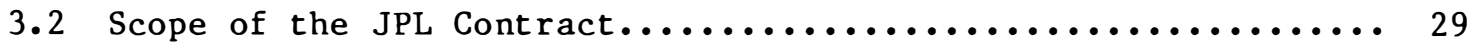

3.3 Summary of the Process and Design Work................. 29

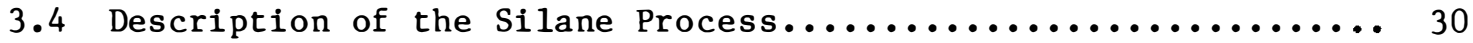

3.5 Calculated Process Impurities....................... 33

3.6 Special Purification Processes....................... 33

3.7 Commercial Availability.......................... 36

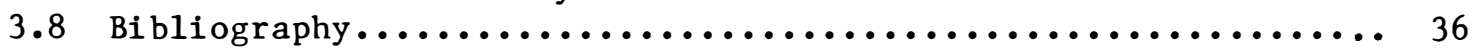

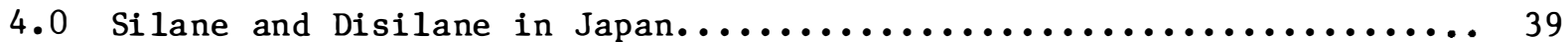

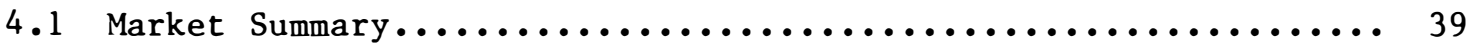

4.2 Commercial Availability........................... 39

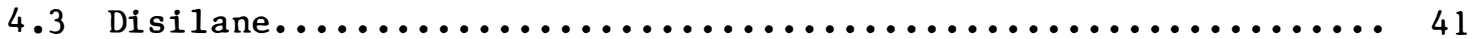

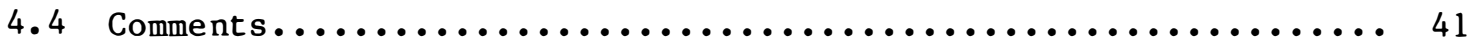

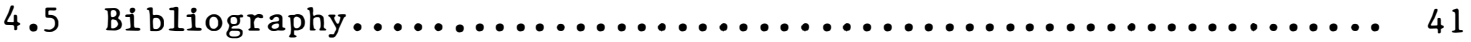

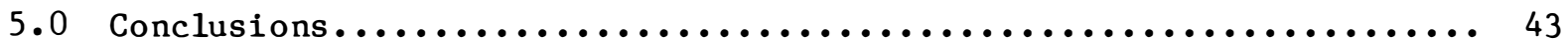

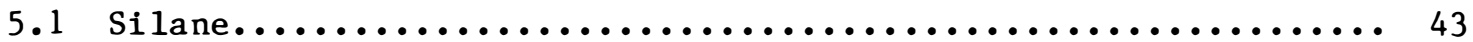

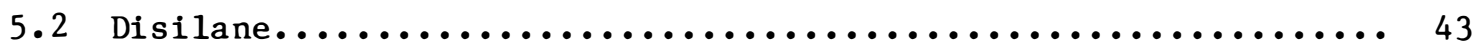

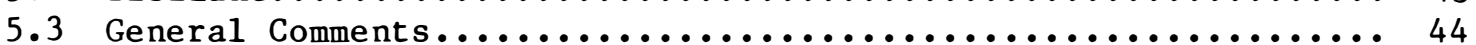

Appendices

A. Typical Silane Composition........................... 45

B. Impurities in Metallurgical Silicon...................... 46

C. Silicon Tetrachloride Sources and Impurities................. 47

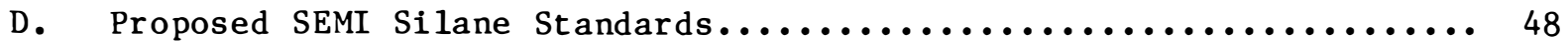

E. Physical Properties of Silane............................ 52

F. Data on Union Carbide Molecular Sieves..................... 53

G. List of U.S. Companies Contacted...................... 57

H. NASA Tech Brief: Purifying Silane....................... 59 
TABLE OF CONTENTS (Concluded)

Page

Appendices (Concluded)

I. NASA Tech Brief: Removing Impurities from Silane..............61

J. NASA Tech Brief: Removing Impurities with the Continuous-

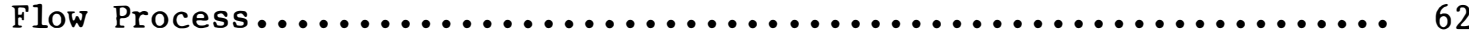

K. Komatsu Silane Data Sheet............................. 63

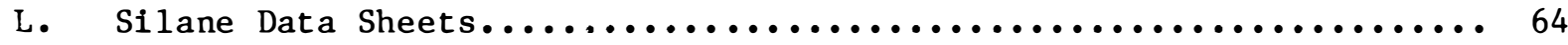




\section{LIST OF FIGURES}

Page

3-1 Flow Schematic of the Union Carbide Silane Process, U1traHigh-Purity Silicon Plant........................... 31

3-2 Block Flow Diagram of the Silane-Silicon Process............. 32

\section{LIST OF TABLES}

2-1 Impurities Detected in Silane: Cylinders 11 through M4........ 10

2-2 Impurities Detected in Silane: Cylinders M5 through M6A......... Il

2-3 Impurities Detected in Silane: Cylinders M7 through B3......... 12

2-4 Impurities Detected in Disilane....................... 13

2-5 Photovoltaic Properties: The Effect of Impurity Gases in Silane... 14

2-6 Silane Prices (U.S. list, July 1983).................... 23

3-1 Calculated Process Impurities for Union Carbide Silane.......... 34

3-2 Union Carbide Silane Process Compound Relative Volatility Factor... 35 
SECTION 1.0

INTRODUCT ION

Monosilane was first prepared in the laboratory in the mid-1880s and further defined along with higher order species in the 1920s. Commercial activity began in the 1960s. The merchant market for silane is still measured in grams, because its only use has been for the deposition of epitaxial layers of silicon or silicon nitride in semiconductor production. In 1980, the total market for silane was estimated to be on the order of $40,000,000$ grams (40 tons). Several firms, such as Komatsu Electronic Metals Company in Japan, began making silane and depositing silicon from it to obtain a very pure polysilicon. These have been the only commercial uses for silane. However, as large markets develop for amorphous silicon arrays in the photovoltaics field and as several companies continue to develop the use of silane for polysilicon production in the United States, improved silane manufacturing processes should result.

This report presents an overview of the current situation concerning silanes in the United States and in Japan. Areas discussed include

- Market summaries

- Published methods for preparing silane

- Discussion of possible impurities

- Impurity levels of commercial silane and disilane

- Published or recommended purification techniques

- Commercial availability of silane and disilane.

The new silane process described in the Jet Propulsion Laboratories/Department of Energy Flat Plate Solar Array Project reports is also reviewed.

For information about the preparation and purification of silanes, a Chemical Abstracts review was conducted from 1967 forward. For the availability section, a questionnaire was sent to producers and/or sellers in the United States and in Japan. Telephone calls and interviews were also used. For the JPL/DOE projects, quarterly and final reports were used. 


\section{SझPI}


SECT ION 2.0

\section{SILANE AND DISILANE IN THE UNTTED STATES}

\subsection{MARKET SUMMARY}

The commercial market for silane began in the 1960s with the development of the semiconductor industry. These uses for epitaxial silicon, silicon oxide, or silicon nitride deposits have grown rapidly over the years. Silane was originally sold in small cylinders and priced by the gram. This practice continues today, even though the volume is now in the many thousands of grams.

As of 1982, the semiconductor business was still the only volume market for silane in the United States. Thus, silane quality and packaging have been based on those needs. Cylinders from lecture-bottle sizes up to 16,000 grams are generally available. Several companies indicate that they will offer tube trailer quotes on request. The prices of silane are volume-sensitive, ranging from $\$ 0.16$ to $\$ 2.50$ per gram.

All of the companies surveyed offered the standard epitaxial deposition resistivity as a measure of purity. None offered an analysis for boron or donors. Direct analysis techniques for determining the boron, arsenic, and phosphorus in silane apparently have not yet been developed. The Semiconductor Equipment and Materials Institute (SEMI) specification analyses are offered for a fee.

Silane for semiconductor uses is sold $100 \%$ or diluted with inert gas. Volumes are given as 100\% equivalents. In 1980, an estimated $35,000 \mathrm{~kg}$ (35 metric tons) was sold in the United States. By 1982, silane use had grown to $40,000 \mathrm{~kg}$. Continued growth of the semiconductor markets is expected. There is no merchant market for solar cells, as yet. The U.S. production capacity for silane is estimated to be over $55,000 \mathrm{~kg}$, plus the silane that will be marketed from the new Union Carbide polysilicon plant of 120 tons.

Disilane is currently offered by four companies: Airco (distributor for Chronar), Matheson, Scientific Gas, and Synthatron. This represents a merchant market for research and development quantities only in 25-, 50-, or $100-$ gram cylinders. The price ranges from $\$ 55.00$ to $\$ 120.00$ per gram.

\subsection{PREPARATION METHODS FOR SILANE}

A literature search yielded data on some 22 methods for preparing silane, most of them found in the literature of the last 20 years. Most of the 22 processes reviewed are research or laboratory methods. Four methods are the ones most commonly used on a commercial scale:

1. Lithium hydride with silicon tetrachloride [5]

2. Lithium hydride with trichlorosilane [5]

3. Magnesium silicide with mineral acids [16] 
4. Catalytic redistribution of chlorosilanes [17].

All of the methods reported here are summarized and referenced.

1. Kuratomi and Yatsurugi [1] claim the following reaction:

$$
2 \mathrm{H}_{2}+\mathrm{Si}(20 \%)+\mathrm{Al}(80 \%)=\mathrm{SiH}_{4}+\mathrm{Al} \text {. }
$$

The patent states that 30 liters per minute of $\mathrm{H}_{2}$ were passed through 600 grams of molten silicon-aluminum $\left(650^{\circ}\right)$ giving 35 grams per hour of silane. The yield is listed at $0.1 \%$. I have not calculated the equilibrium involved, but the JANAF tables [43] present data for the free energy of formation of silane. Experts advise that an equilibrium mixture of hydrogen, silicon, and silane at any temperature could contain only a few ppm of silane. The $0.1 \%$ yield is some 2000 times the calculated equilibrium. This small yield could have been due to impurities in the silicon.

2. Jackson, Marsh, and Muetterties [2] report the reaction:

$$
\begin{aligned}
& 2 \mathrm{Al}+\mathrm{AlCl}_{3}+3 \mathrm{H}_{2}=3 \mathrm{AlH}_{2} \mathrm{Cl} \\
& 2 \mathrm{AlH}_{2} \mathrm{Cl}+\mathrm{SiO}_{2}=\mathrm{SiH}_{4}+2 \mathrm{~A} 10 \mathrm{Cl} \text {. }
\end{aligned}
$$

The first reaction to form aluminum haloalane was carried out at $200^{\circ} \mathrm{C}$ and 900 atm. The second was done at "moderate conditions". This does not appear to be a reaction to scale-up.

3. Amberger and Boeters [3] claim the following:

$$
3 \mathrm{SiO}_{2}+4 \mathrm{Al}+12 \mathrm{H}_{2}=2 \mathrm{Al}_{2} \mathrm{O}_{3}+3 \mathrm{SiH}_{4} \text {. }
$$

This was done at high temperatures, and the probability of getting silicon metal is great.

4. Tachiki and Yamashita [4] claim the use of hydrogen sulfide or sulfides of copper, silicon, or nickel as catalysts for the reaction of hydrogen with powdered silicon at $35^{\circ} \mathrm{C}$ and $50 \mathrm{~atm}$. They further claim that by controlling the ratios of $\mathrm{H}_{2}$ to silicon, a high yield of any desired silane from $\mathrm{SiH}_{4}$ to $\mathrm{Si}_{5} \mathrm{H}_{12}$ can be prepared. This would have to be reviewed very carefully. Thermodynamic data predicts a yield of $10 \mathrm{ppb}$ of silane.

5. One of the more popular methods uses lithium hydride. Sundermeyer [5] was granted several patents in the early 1960s for the semicontinuous preparation of silane. Electrolysis of a LiCl/KCl mixture at $400^{\circ} \mathrm{C}$ for 4 minutes at $4 \mathrm{~V}, 32 \mathrm{~A}$ yielded lithium metal at $75 \%$ efficiency. Lithium was reacted with hydrogen to give lithium hydride. LiH was reacted with $\mathrm{SiCl}_{4}$ to give $\mathrm{SiH}_{4}$ at $73 \%$. The yield was $99.5 \%$ when excess $\mathrm{SiCl}_{4}$ was used. Purity was in ppm. Later, Sundermeyer and Litz [6] reported a continuous operation.

Litz and Ring [7] in 1964 patented a process for the electrolysis of a molten lithium chloride/sodium chloride eutectic to produce lithium metal at the cathode and silicon tetrachloride at the silicon anode. 
The lithium metal is converted to the hydride by contact with gaseous hydrogen. Lithium hydride is then reacted with the silicon chloride to form silane. One could start with LiH, if this were available. Also, trichloro or dichlorosilane could be the silicon source.

Pavlov et al. [8] prepared silane by bubbling a $\mathrm{SiCl}_{4}-\mathrm{H}_{2}$ mixture through a melt of $\mathrm{LiH}$ in a eutectic mixture of LiC1/KCl. The silane yield was $95 \%$ with some disilane and $\mathrm{HCl}$ and 1 ess than $0.01 \%$ of boron, gallium, phosphorus, and antimony.

Franklin, Francis, and Tarancon [9] have a 1976 patent on preparing silane in a single chamber from the above reactions. They merely state that the silicon made from this silane is sufficiently pure for electronic-grade uses.

A 1981 patent to Komatsu [10] describes a nickel system for carrying out this reaction. Although this process is one of the better ones, the silane produced most likely needs some clean-up before use. These reactions are used commercially.

6. In 1968, Vit et al. [11] patented the use of sodium hydride or sodium aluminum hydride with silicon tetrachloride to make silane in a boiling tetrahydrofurane system.

7. Weiss and Fisher [12] describe the reaction of $\mathrm{SiO}_{2}$ with $\mathrm{LiAlH}_{4}$ at $200^{\circ} \mathrm{C}$, claiming that ether is the only recognized impurity. This would certainly have to be reviewed by today's standards. Bellama and MacDiarmid [13] list the same reaction, but at $170^{\circ}$. They obtained a $7 \%$ yield.

8. Finholt et al. [14] describe a simple laboratory method: add $\mathrm{SiCl}_{4}$ to a mixture of $\mathrm{LiAlH}_{4}$ in diethyl ether at liquid nitrogen temperatures, then let it warm up to $0^{\circ} \mathrm{C}$. This technique gives silane with a $99 \%$ yield. Jernejcic [15] and Norman et al. [16] also report this reaction.

9. Roy [17] prepared silane by the reaction of $\mathrm{SiCl}_{4}$ with $\mathrm{NaBH}_{4}$ in a diglyme (a polyether) at ambient temperature. No purity is listed.

10. Hance and Wagner [18] reacted triethoxysilane with sodium to obtain silane.

11. Kuratomi and Kawakita [20] placed powdered silicon and nickel nitrate in a high-pressure reactor and then treated this with hydrogen to form free nickel. Further addition of hydrogen produced $85 \%$ monosilane.

12. Lorenz and Whaley [21,22] prepared siloxene from calcium silicide and acid and reacted this with ammonia to obtain silane. A yield of $37 \%$ monosilane was obtained with less than $0.1 \%$ higher silanes.

13. Kuratomi and Yatsurugi [23] reacted $\mathrm{SiCl}_{4}$ and hydrogen in a molten alloy of 50/50 potassium and sodium to get silane. The product gave a deposited silicon of $50 \mathrm{ohm}-\mathrm{cm}$. 
14. Kuratomi [24] states that $\mathrm{SiCl}_{4}$ with hydrogen at $200^{\circ}-550^{\circ} \mathrm{C}$ in the presence of titanium sponge or titanium hydride gives $37 \%$ trichlorosilane, $21 \%$ dichlorosilane, $13 \%$ monochlorosilane, and $8 \%$ silane.

15. Tachiki et al. [25] sintered magnesium, silicon, and zinc in a reducing atmosphere, powdered the sinter and added sulphuric acid to get $99.5 \%$ pure silane in a $90 \%$ yield.

16. Stock, in his book published in 1933 [26], described the preparation of magnesium silicide reacted with $\mathrm{HCl}$ to yield silanes. He states that $25 \%$ of the silicon was converted to silanes: $40 \% \quad \mathrm{SiH}_{4}, 30 \%$ $\mathrm{Si}_{2} \mathrm{H}_{6}, 15 \% \mathrm{Si}_{3} \mathrm{H}_{8}$ and some higher silanes. Feher [27] adds that having $20 \%$ phosphoric acid present aids the reaction toward monosilane. Johnson [28] reports that $\mathrm{HBr}$ works quite well also.

Kuratomi and Yatsurugi [29] found that $\mathrm{Mg}_{2} \mathrm{Si}$ with $\mathrm{NH}_{4} \mathrm{SCN}$ dissolved in liquid ammonia gave only a trace of higher silanes. Ebsworth [41] found the magnesium silicide with acid reaction gave a $50 \%$ yield of silane when run in hydrazine at $50^{\circ} \mathrm{C}$. Yusa, Yatsurugi, and Takaishi [33] report that in the current industrial process, silane is generated by reacting magnesium silicide with ammonium chloride in liquid ammonia solution at $0^{\circ} \mathrm{C}$. These reactions are well documented and are quite straightforward for silane production. At least one of these reactions is used commercially. For higher silanes, economics and purity would have to be studied carefully.

17. Bakay [30], in his 1976 patent, described this process: silane is obtained by introducing $\mathrm{SiHCl}_{3}$ into an ion exchange resin consisting of tertiary and quaternary ammonium groups at $20^{\circ}$ to $200^{\circ} \mathrm{C}$. Litteral [31] in 1978 found this reaction could also be done in two steps: trichlorosilane is passed over the resin to make dichlorosilane, and a second pass through the resin gives silane. This process has been used by Union Carbide since 1970 to make dichlorosilane and is discussed in the section on the JPL/DOE process.

18. Calcote [32] in his work on low-cost silicon under the JPL/DOE solar array project reported the preparation of high-purity silane in a nonequilibrium jet plasma with sodium and $\mathrm{SiCl}_{4}$ feed. This gave a very low yield.

19. Kutznetsov [34] states that $\mathrm{NaH}$ with trialkyl aluminum compounds reduces tetraethoxysilane to silane, with the yield depending on the order of additions--and complicated by side reactions.

20. Isano et al: [35] noted that silane can be prepared by decomposing triethoxysilane in the presence of sodium methoxy dissolved in tet raethoxysilane.

21. Kuratomi and Kawakita [36] reacted $\mathrm{KOH}, \mathrm{KH}$, and $\mathrm{SiCl}_{4}$ at $370^{\circ} \mathrm{C}$ for silane. 
22. LeFrancois $[37,44]$, in his 1982 patent, presents the preparation of silane by the reaction of a silicon halide, such as silicon tetrafluoride, with alkali metal hydrides, such as sodium hydride, in a liquid that includes a diaryl ether such as diphenyl ether. At elevated temperatures, such as $250^{\circ}-260^{\circ} \mathrm{C}$, complete conversion of the silicon tetrahalide to silane was observed, even with contact times under 2 seconds.

This patent, assigned to Allied Corporation, claims the use of silicon chlorides, bromides, or iodides alone or in mixtures with sodium, lithium, or potassium hydrides. Silicon tetrafluoride is preferred, because it is an available by-product in the manufacture of phosphoric acid. Vigorous stirring is required--5,000 to 10,000 rpm. One example cited is $\mathrm{NaH}$ in mineral oil slurried in diphenyl ether/ biphenyl. With stirring, equimolar parts of nitrogen and $\mathrm{SiF}_{4}$ are flowed in at $255^{\circ} \mathrm{C}$. The effluent gas contains $40 \% \mathrm{~N}_{2}, 2 \% \mathrm{SiF}_{4}$, and $56 \% \mathrm{SiH}_{4}$. Other peaks on the gas chromatograph eluting after silane could be higher silanes. Solid products were equal parts of $\mathrm{NaF}$ and $\mathrm{Na}_{2} \mathrm{SiF}_{6} \cdot \quad$ No purities were given, but the common impurities found in other methods would probably be present in the silane.

\subsection{PREPARATION METHODS FOR HIGHER SILANES}

There are very few publications on the higher silanes. The most definitive work was done and reported by Stock in 1933 [26]. Dropping magnesium silicide, prepared by reducing silica with metallic magnesium at high temperatures, into aqueous hydrochloric acid solution, formed silanes. The evolving gases had this approximate composition: $40 \%$ silane, $30 \%$ disilane, $15 \%$ trisilane, $10 \%$ tetrasilane, and $7 \%$ higher silanes.

Johnson and Isenberg [38] studied the preparation of magnesium silicide and its reaction in ammonia and ammonium bromide at low temperatures. They concluded that the yield of disilane was determined by the temperature of the reaction, the nature of the solvents, and the composition of silicides used. If they prepared their magnesium silicide at temperatures of $500^{\circ}-900^{\circ} \mathrm{C}$, where they state that only the MgSi species can survive, mostly monosilane was obtained. If the silicide was prepared at $400^{\circ}-500^{\circ} \mathrm{C}$, higher magnesium silicides appeared, such as $\mathrm{Mg}_{2} \mathrm{Si}_{2}$. This silicide species favors the formation of disilane. Also, the disilane yield is increased if the silicide is reacted in the ammonia/ammonium bromide solution at $50^{\circ} \mathrm{C}$ instead of at $-35^{\circ} \mathrm{C}$. In these cases, the disilane in the product was increased from a few percent to $50 \%-60 \%$. Using traps at various temperatures effects a separation of the silanes.

Finholt et al. [14] in 1947 under a Naval esearch project, defined the lithium aluminum hydride method for higher silanes. When silicon halides are used with $\mathrm{LiAlH}_{4}$ in an ether solution at liquid nitrogen temperature, and warmed to room temperature, an almost complete reaction occurs. When silicon tetrachloride is used, a $99 \%$ yield of silane is obtained. Lithium hydride could also be used, but the reaction is slower. When hexachlorodisilane is used, an $87 \%$ yield of disilane can be obtained. If octochlorotrisilane is used, trisilane resulted. The higher order chlorosilanes are a by-product in 
the manufacture of silicones. Because of no market, they are not normally isolated. They can easily be cracked back into useful silicone monomers.

In their 1961 patent, Tachiki and Yamashita [4] claim the use of $\mathrm{H}_{2} \mathrm{~S}$ or sulfides of $\mathrm{Ni}, \mathrm{Cu}$, or $\mathrm{Si}$ as catalysts for the reaction of hydrogen with powdered silicon at $35^{\circ}$ and at 50 atm. If the ratios of $\mathrm{H}_{2}$ to silicon are controlled, any desired silane can be prepared from $\mathrm{SiH}_{4}$ to $\mathrm{Si}_{5} \mathrm{H}_{12}$. For example: Using $190.8 \mathrm{~L}$ of $\mathrm{H}_{2}$, Tachiki obtained $95 \% \mathrm{SiH}_{4}$. With $158.5 \mathrm{~L}$ of $\mathrm{H}_{2}, 92 \%$ disilane was achieved, and with $120.5 \mathrm{~L}$ of $\mathrm{H}_{2}, 98 \% \mathrm{Si}_{5} \mathrm{H}_{12}$ resulted. This work would have to be verified.

Gasper, Levy, and Adair [42] prepared trisilane by reducing $\mathrm{Si}_{3} \mathrm{Cl}_{8}$ with $\mathrm{LiAlH}_{4}$ in butyl ether in vacuum. All of these methods are used in development or in small-scale commercial uses.

\subsection{POSSIBLE MPURITIES AND MPPURTY LAVELS IN COMGRCIAL SILANBS}

To some degree, the impurities found in a product will be related to the purity of the starting materials. For silane, the silicon source is most likely related to metallurgical silicon; typical analyses are given in Appendix B. Since most of the silane made in the United States uses a chlorosilane, these impurities could be carried through into the silane. Note that the elements of Group III (B), Group V (P, As, Sb) and lots of heavy metals are present. If silicon tetrachlorosilane is used, sources and possible impurities are as given in Appendix C. Here again, most of the elements listed above would be present. Even if one uses silicon tetrachloride from the polysilicon effluent, contaminants from the reducing agents would introduce quite a few elements. Stone [40] studied the composition of silanes prepared by the magnesium silicide method. He found some 21 compounds could be present, including silane, and higher silanes up to $\mathrm{Si}_{8}{ }^{\mathrm{H}}{ }_{18}$. A typical process silane composition is given in Appendix A.

Almost all of the producers and sellers of silane indicated that they had a proprietary purification technique. However, they are generally considering only those impurities which are critical in current semiconductor uses. Analyses are typically run on silane for contained gases, nitrogen, oxygen, hydrogen, argon, chlorosilanes, carbon as monoxide or dioxide, and methane. Electrical properties are checked by deposition of a thin silicon layer on a silicon wafer. The resistivity of a standard electronic-grade wafer typically ranges from 50 to $150 \mathrm{ohm}-\mathrm{cm}$. This property determines the quality grade. Several companies are advertising $1000 \mathrm{ohm}-\mathrm{cm}$ silane--the uniformity and use of this material will have to be determined. Incidentally, the resistivity of the epitaxial deposit does not directly correlate with what the silane would provide in a poly or amorphous deposition. It is not an indicator of the level of donors or acceptors.

Silane for semiconductor use is generally evaluated by the deposition of a very thin layer of silicon onto a single-crystal silicon wafer. The silicon grows on the same orientation (or axis) as the crystal in the wafer. Hence, the name epitaxial: same axis. The resistivity of the deposited layer is then measured to give a compensated resistivity. In silicon, the acceptors-normally boron--and the donors--normally phosphorus and arsenic--neutralize 
each other, atom for atom. Thus, we obtain the overall electrical measurement of resistivity and type. The type of resistivity is p (positive) for excess boron or $n$ (negative) for excess phosphorus or arsenic. So, the boron level could be 10 ppba and the phosphorus level 8 ppba to give a 2 ppba excess of boron, setting the resistivity of $140 \mathrm{ohm}-\mathrm{cm}, \mathrm{p}-t y p e$. Or it could also be 62 ppba of boron and 60 ppba of phosphorus for the same resistivity reading. One really needs to know actual levels of the impurities. It follows, then, that a resistance of $2000 \mathrm{ohm}-\mathrm{cm}$ on the deposited layer merely means that the difference in atoms is $0.12 \mathrm{ppba}$. In the single-crystal silicon area, high levels of $B$ or P or any impurity can cause "dislocation" as the crystals grow. These can also cause uneven electrical properties.

The need for control or knowledge of the actual levels of elements in the silicon is yet to be determined for the amorphous area. Controlled levels of boron and phosphorus result in a more uniform product. Moreover, the presence of heavy metals can affect the long-term stability of the product. Group III (B) and Group V ( $P$ and A, etc.) analyses are not normally run on silane. Union Carbide suggests that these analyses are not easy to run and acceptable processes will have to be developed.

Brookhaven National Laboratory has run studies on the concentration of volatile impurities in selected cylinders of commercial silane and disilane. This work was performed under the auspices of the U.S. Department of Energy, Division of Materials Sciences, Office of Basic Science, under Contract DE AC02 76CH00016. One segment of this study published recently [45] indicates that impurity levels of $20 \mathrm{ppm}$ can affect the electronic properties of amorphous silicon cells. Further detailed data provided by R. Corderman [46] are given in Tables 2-1, 2-2, and 2-3 for silane and in Table 2-4 for disilane. These data indicate the wide range of impurity levels (from $10 \mathrm{ppm}$ to $11,500 \mathrm{ppm}$ ) in various selected commercial silane products, and that filters can remove some of the impurities. These were proprietary filters, but it is known that chlorosilanes and siloxanes can be removed by passing the silane over activated charcoal. Corderman found that chlorosilanes in silane most likely react with moisture present to form siloxanes. Either one of these species can reduce the short-circuit current and the fill factor of amorphous photovoltaic devices. The newer, high-resistivity grades of silane generally show reduced impurity levels. A purer disilane should also be available soon.

From these data we can surmise that the following impurities could be present in commercial silane: atmospheric and rare gases, methane, carbon oxides, chlorosilanes, higher silanes, boron, phosphorus, antimony, and arsenic. The impurities in disilane would be expected to be the same as in silane, with the possible addition of higher order carbon compounds such as $\mathrm{C}_{2} \mathrm{H}_{4}, \mathrm{C}_{2} \mathrm{H}_{6}$, and $\mathrm{C}_{3} \mathrm{H}_{8} \cdot$

Most companies use gas chromatography to determine impurities, and epitaxial deposition for resistivity. Metal impurities are not normally run. One analysis showed quantities from 0.1 to 0.005 ppmw of iron, sodium, chromium, potassium, zinc, copper, nickel, lead, and tin. All commercial silanes seem to be n-type; that is, they yield n-type epitaxial films. This means the Group V elements--such as $P$ and As--are dominant, which could be the reason that most amorphous silicon intrinsic layers are slightly n-type. 
Table 2-1. Impurities Detected in Silane: Cylinders Ml through M4

\begin{tabular}{|c|c|c|c|c|c|}
\hline $\begin{array}{l}\text { Cylinder: } \\
\text { Supplier: } \\
\text { Grade: }\end{array}$ & $\begin{array}{c}\text { Ml } \\
\text { Matheson } \\
\text { Semi conductor }\end{array}$ & $\begin{array}{l}\text { M2 w/o Filter } \\
\text { Matheson } \\
\text { Semi conduct or }\end{array}$ & $\begin{array}{l}\text { M2 w/Filter } \\
\text { Matheson } \\
\text { Semiconductor }\end{array}$ & $\begin{array}{c}\text { M3 } \\
\text { Matheson } \\
\text { Semiconductor }\end{array}$ & $\begin{array}{c}\text { M4 } \\
\text { Matheson } \\
\text { Semi conductor }\end{array}$ \\
\hline \multicolumn{6}{|l|}{ Species } \\
\hline $\mathrm{HCl}$ & 200 & 8,500 & 290 & 920 & 30 \\
\hline $\mathrm{SiH}_{3} \mathrm{Cl}$ & 320 & 3,000 & 10 & -- & 10 \\
\hline $\mathrm{SiH}_{2} \mathrm{Cl}_{2}$ & - & -- & -- & -- & - \\
\hline $\mathrm{SiCl}_{4}$ & -- & -- & -- & -- & - \\
\hline $\mathrm{SiH}_{3} \mathrm{OSiH}_{3}$ & 360 & 3,600 & 170 & 1,100 & 170 \\
\hline$\left(\mathrm{SiH}_{3} \mathrm{O}\right)_{2} \mathrm{SiH}_{2}$ & -- & 190 & 10 & 100 & -- \\
\hline $\mathrm{SiH}_{3}\left(\mathrm{OSiH}_{2}\right)_{2} \mathrm{OSiH}_{3}$ & -- & 50 & - & - & -- \\
\hline $\mathrm{Si}_{2} \mathrm{H}_{6}$ & 900 & 1,800 & 80 & 1,100 & 110 \\
\hline Total [Cl] & 520 & 11,500 & 300 & 920 & 40 \\
\hline Total [0] & 360 & 3,840 & 180 & 1,200 & 170 \\
\hline
\end{tabular}

Source: Brookhaven National Laboratory

Note: All numbers are in $\mathrm{ppm}$, with the measured data rounded to give two digits of precision; balance is $\mathrm{SiH}_{4}(10,000 \mathrm{ppm}=1 \%)$.

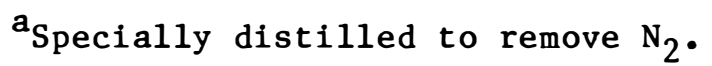

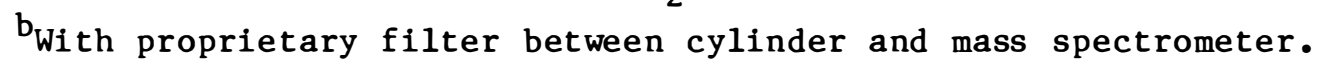


Table 2-2. Impurities Detected in Silane: Cylinders M5 through M6A

\begin{tabular}{|c|c|c|c|c|c|}
\hline $\begin{array}{l}\text { Cylinder: } \\
\text { Supplier: } \\
\text { Grade: }\end{array}$ & $\begin{array}{c}\text { M5 } \\
\text { Matheson } \\
\text { Semiconduct or }\end{array}$ & $\begin{array}{l}\text { Il } \\
\text { Ideal } \\
\text { TOPS }\end{array}$ & $\begin{array}{l}\text { I2 } \\
\text { Idea1 } \\
\text { TOPS }\end{array}$ & $\begin{array}{l}\text { M6 } \\
\text { Matheson } \\
\text { Purity }\end{array}$ & $\begin{array}{l}\text { M6A } \\
\text { Matheson } \\
\text { Purity }\end{array}$ \\
\hline \multicolumn{6}{|l|}{ Species } \\
\hline $\mathrm{HCl}$ & 210 & 10 & 620 & -- & 60 \\
\hline $\mathrm{SiH}_{3} \mathrm{Cl}$ & 50 & 20 & -- & 10 & -- \\
\hline $\mathrm{SiH}_{2} \mathrm{Cl}_{2}$ & -- & -- & 400 & -- & $\cdots$ \\
\hline $\mathrm{SiCl}_{4}$ & -- & -- & 340 & -- & -- \\
\hline $\mathrm{SiH}_{3} \mathrm{OSiH}_{3}$ & 260 & 20 & 100 & 90 & 190 \\
\hline$\left(\mathrm{SiH}_{3} \mathrm{O}\right)_{2} \mathrm{SiH}_{2}$ & -- & -- & -- & -- & -- \\
\hline $\mathrm{SiH}_{3}\left(\mathrm{OSiH}_{2}\right)_{2} \mathrm{OSiH}_{3}$ & -- & -- & $\cdots$ & -- & $\ldots$ \\
\hline $\mathrm{Si}_{2} \mathrm{H}_{6}$ & 120 & 230 & 2,900 & 60 & 240 \\
\hline Total [C1] & 260 & 30 & 1,360 & 10 & 60 \\
\hline Total [0] & 260 & 20 & 100 & 90 & 190 \\
\hline
\end{tabular}


Table 2-3. Impurities Detected in Silane: Cylinders M7 through B3

\begin{tabular}{|c|c|c|c|c|c|}
\hline $\begin{array}{l}\text { Cylinder: } \\
\text { Supplier: } \\
\text { Grade: }\end{array}$ & $\begin{array}{c}\text { M7 } \\
\text { Matheson } \\
\text { Purity }\end{array}$ & $\begin{array}{l}\mathrm{M}^{\mathrm{a}} \\
\text { Matheson } \\
\text { Purity }\end{array}$ & $\begin{array}{c}\mathrm{LCl} \\
\text { Liquid Carbonic } \\
\text { CCD }\end{array}$ & $\begin{array}{c}\mathrm{Bl}^{\mathrm{a}} \\
\text { Matheson } \\
\text { Semiconductor }\end{array}$ & $\begin{array}{c}\text { B3 }^{\mathrm{a}} \\
\text { Matheson } \\
\text { Purity }\end{array}$ \\
\hline \multicolumn{6}{|l|}{ Species } \\
\hline $\mathrm{HCl}$ & -- & -- & 30 & 210 & -- \\
\hline $\mathrm{SiH}_{3} \mathrm{Cl}$ & -- & -- & 10 & 50 & -- \\
\hline $\mathrm{SiH}_{2} \mathrm{Cl}_{2}$ & -- & -- & -- & -- & -- \\
\hline $\mathrm{SiCl}_{4}$ & -- & -- & -- & -- & -- \\
\hline $\mathrm{SiH}_{3} \mathrm{OSiH}_{3}$ & -- & 30 & 80 & 270 & -- \\
\hline$\left(\mathrm{SiH}_{3} \mathrm{O}\right)_{2} \mathrm{SiH}_{2}$ & -- & -- & -- & -- & -- \\
\hline $\mathrm{SiH}_{3}\left(\mathrm{OSiH}_{2}\right)_{2} \mathrm{OSiH}_{3}$ & -- & -- & -- & -- & -- \\
\hline $\mathrm{Si}_{2}{ }^{\mathrm{H}} 6$ & 280 & 180 & 50 & 220 & 90 \\
\hline Total [Cl] & 0 & 0 & 40 & 260 & 0 \\
\hline Total [0] & 0 & 30 & 80 & 270 & 0 \\
\hline
\end{tabular}

Source: Brookhaven National Laboratory.

Note: All numbers are in ppm, with the measured data rounded to give two digits of precision; balance is $\mathrm{SiH}_{4}(10,000 \mathrm{ppm}=1 \%)$.

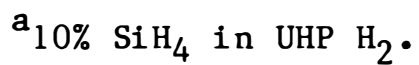


Table 2-4. Impurities Detected in Disilane

\begin{tabular}{|c|c|c|c|}
\hline $\begin{array}{l}\text { Cylinder: } \\
\text { Supplier: }\end{array}$ & $\begin{array}{ll} & \text { DS1 } \\
\text { KOR Isotopes }\end{array}$ & $\begin{array}{c}\text { DS2 } \\
\text { Chronar }\end{array}$ & $\begin{array}{c}\text { DS3 } \\
\text { Chronar }\end{array}$ \\
\hline \multicolumn{4}{|l|}{ Species } \\
\hline $\mathrm{HCl}$ & 540 & -- & - \\
\hline $\mathrm{Si}_{2} \mathrm{H}_{5} \mathrm{Cl}$ & 120 & -- & -- \\
\hline $\mathrm{CO}_{2}$ & -- & -- & 48,750 \\
\hline $\mathrm{SiH}_{3} \mathrm{OSiH}_{3}$ & -- & - & 6,200 \\
\hline $\mathrm{Si}_{2} \mathrm{H}_{5} \mathrm{OSiH}_{3}$ & -- & 600 & -- \\
\hline$\left(\mathrm{Si}_{2} \mathrm{H}_{5}\right)_{2} \mathrm{O}$ & 860 & -- & $\cdots$ \\
\hline $\mathrm{Si}_{3} \mathrm{H}_{8}$ & 2,600 & 26,000 & 6,400 \\
\hline $\mathrm{Si}_{4} \mathrm{H}_{10}$ & 70 & 410 & 330 \\
\hline Total [C1] & 660 & 0 & 0 \\
\hline Total $[0]$ & 860 & 600 & 54,950 \\
\hline
\end{tabular}

Source: Brookhaven National Laboratory.

Note: All numbers are in ppm, with the measured data rounded to give two digits of precision; balance is $\mathrm{Si}_{2} \mathrm{H}_{6}$ and most likely some $\mathrm{SiH}_{4}$ $(10,000 \mathrm{ppm}=1 \%)$.

\subsection{PURIFICAT ION TECHNIQUES}

A search of the Chemical Abstracts was made on purification techniques for the period 1960 to date. Some 24 references are reported in this subsection.

Monosilane has been prepared and used in the semiconductor industry for some twenty years. Most of the purity requirements were related to obtaining an epitaxial layer of silicon, where the electron donors and acceptors can be controlled. The major impurities of concern were those listed in the proposed SEMI standards C3STD8, 9, and 10, as shown in Appendix D. These specifications list the maximum parts-per-million levels of oxygen, hydrogen, water, carbon oxides, hydrocarbons as methane, chlorosilanes, and rare gases as 3 to 10,000 .

These specifications relate basically to semiconductor uses. Specifications will have to be set up for silanes for solar energy uses. For example, hydrogen in the silane should not be a problem for solar cell uses. Some chlorosilanes may even be useful, since it has been reported that some halides enhance the ability of the deposited amorphous silicon to be easily doped. The level of Group III and V elements will probably be important, because they determine the electrical properties. Dissolved gases such as oxygen and the heavy metals in crystalline silicon determine the lifetime of the device, as these elements tend to combine with the useful elements. We presume that similar actions can occur in amorphous silicon. 
The use of silane to produce polysilicon was considered in the early 1960 s and prompted further investigation into purity. One U.S. company, Trancoa, operated a polysilicon plant for several years. They deposited silicon from silane on the external surface of an internally heated quartz tube. The quartz shattered upon cooling and was removed by acid leaching. The silane was made from the lithium hydride-silicon tetrachloride method. Around 1970, Komatsu began producing very pure silicon from silane.

Dr. Carlson and his team also studied the effects of various impurity gases in silane on glow-discharge-formed amorphous silicon [47]. His data are summarized in Table 2-5.

Of these contaminants, all showed some detrimental effect, but water, sulfide, phosphine, and chlorosilanes caused severe decreases in properties. The data also show that amorphous silicon can accommodate relatively large concentrations of impurities and still exhibit significant photovoltaic effect. Thus, a more pure starting material might be very useful, for it appears that the correlation of impurities in silane to cell properties is strong. In another report [48], Dr. Carlson's team found that carbon materials such as methane in silane cause increased resistivity, which lead to problems with contacts and lower solar cell performance. The Brookhaven data (in Section 2.4) indicate that all currently available commercial silanes contain various levels of impurities. Researchers should obtain a cylinder analysis from their suppliers.

Additional data on the effects of air, oxygen, nitrogen, phosphine, and monochlorosilane on amorphous silicon solar cells are given in an article by Delahoy and Griffith [74].

Table 2-5. Photovoltaic Properties: The Effect of Impurity Gases in Silane

\begin{tabular}{llcc}
\hline $\begin{array}{c}\text { Impurity Gas } \\
(\text { Vol. of total atm.) }\end{array}$ & $\begin{array}{c}\text { Voc } \\
(\mathrm{mV})\end{array}$ & $\begin{array}{c}\text { Jsc } \\
\left(\mathrm{mA} / \mathrm{cm}^{2}\right)\end{array}$ & $\begin{array}{c}\text { Fill } \\
\text { Factor }\end{array}$ \\
\hline None--control & 700 & 6.0 & 0.54 \\
$2.3 \% \mathrm{H}_{2} \mathrm{O}$ & 400 & 0.6 & 0.23 \\
$2.3 \% \mathrm{H}_{2} \mathrm{~S}$ & 425 & 3.0 & 0.21 \\
$1.0 \% \mathrm{GeH}_{4}$ & 370 & 3.0 & 0.21 \\
$10 \% \mathrm{CH}_{4}$ & 662 & 4.0 & 0.53 \\
$30 \% \mathrm{CH}_{4}$ & 230 & 0.02 & 0.18 \\
$10 \% \mathrm{~N}_{2}$ & 595 & 6.0 & 0.55 \\
$0.06 \% \mathrm{PH}_{3}$ & 130 & 1.5 & 0.42 \\
$50 \% \mathrm{SiH}_{2} \mathrm{Cl} 2$ & 321 & 0.05 & 0.25 \\
\hline
\end{tabular}




\subsubsection{Properties of Silane}

The basic properties of silane are listed in Appendix E. The various silanes have a wide range of boiling points. Early workers found it easy to separate monosilane from the di- or tristlanes by cooling the mixture below $-130^{\circ} \mathrm{C}$ and then taking off each species as it warmed up to its boiling point.

Silane is generally listed as spontaneously flammable in air. My experience is that very pure monosilane does not spontaneously ignite in air. Most probably, all monosilane contains some di- or trisilane, which does ignite on exposure to air. Silane does not react with neutral water, ammonia, or metal hydrides. It will react with halogens, bases, and alcohols and will reduce salts to their base metal. Silane is ordinarily stable at temperatures up to $380^{\circ}-400^{\circ} \mathrm{C}$. These properties allow several different purification processes, unique to silane, to be used. A further listing of properties is given by Yaws et al. in his article "Physical and Thermodynamic Properties of Silane," published in the January 1978 issue of Solid State Technology.

\subsubsection{Purification Processes}

The various techniques for purifying silane involve selective reactivity, selective sorption, distillation, or a combination of these.

1. Chalupa et al. [51] found that scrubbing crude silane with a solution of sodium and liquid ammonia produced a product suitable for manufacturing semiconductors (1961).

2. Lewis et al. [52] reporting on an Air Force-sponsored study by Metal Hydrides, Inc. and Cambridge Labs, lists several techniques for purifying silane. A liquid ammonia scrubber is suggested for removing boron complexes. Activated carbon, at temperatures below zero, is an adsorbent for diborane and arsine. (This should also remove other polar molecules--phosphine and chlorosilanes.) Passing silane through a hot tube at $350^{\circ} \mathrm{C}$ should decompose hydrides of germanium, lead, gallium, and antimony. After these treatments, silane with only ppb impurities resulted.

3. A British patent [53] states that silane can be freed from arsine by passing it through activated carbon in a vessel at $-78^{\circ} \mathrm{C}$, imbedded in solid $\mathrm{CO}_{2}$. Diborane can be removed by passing it through the same material at $0^{\circ}$ to $-30^{\circ} \mathrm{C}$. The saturated charcoal may be reactivated by flushing it with argon at $200^{\circ} \mathrm{C}$.

4. Caswell and LeFever [54], in a German patent, treated silane with finely divided metals ( $\mathrm{Li}, \mathrm{Rb}, \mathrm{Cs}, \mathrm{Ba}, \mathrm{Sr}$, or $\mathrm{Mg}$ ) to remove boron. The boron complex $\left(\mathrm{B}_{2} \mathrm{H}_{6} 2 \mathrm{Na}\right)$ is easily removed. The reactive metal can be on an adsorbing agent as a carrier, such as sodium on silica gel, on activated alumina, or on a crystalline zeolite.

5. A Netherlands patent [55] states that $98 \%$ silane, with impurities of hydrogen, chlorosilanes, silicon tetrachloride, helium, siloxane, disilane, arsine, phosphine, and diborane is purified by distilling it 
at $-10^{\circ}$ to $-70^{\circ} \mathrm{C}$ into porous wood charcoal and then into porous magnesium silicate at $-40^{\circ}$ to $-80^{\circ} \mathrm{C}$. The impurities come off the top; the silane, off the bottom. This is then passed through granular wood charcoal at $-10^{\circ}$ to $-50^{\circ} \mathrm{C}$. The resulting silane is "practically" pure.

6. Asano et al. [56] used carbon and a synthetic zeolite of 0.5 to $0.9 \mathrm{~nm}$ pore size to remove ethyl and ethoxy impurities from their silane prepared from triethoxysilane. Less than $0.2 \mathrm{ppm}$ of these impurities remain in the silane.

7. Cowlard [57] states that crude silane can be purified by passing it through a molecular sieve above $0^{\circ} \mathrm{C}$. He suggests a type $5 \mathrm{~A}, 13 \mathrm{X}$ mixture of synthetic zeolites. The purified silane gave a deposited silicon of 100 ohm-cm, p-type. (Data on Linde molecular sieves is listed in Appendix F.)

8. Ohgushi et al. [58] explain the molecular sieving action on an ion exchange zeolite A. Using a potassium A zeolite, they exchanged the cation with divalent metal elements and determined the adsorption of phosphine from silane. A mechanism is proposed.

9. Takaishi and Gomi [59] have suggested a compact purifier for silane to remove what they believe to be the major impurity in commercial silane--phosphine. They advocate the use of potassium-zinc A zeolite which, they state, selectively adsorbs phosphine. They passed 1-3 L/min of a 5/95 mixture of silane/hydrogen through the zeolite column at $-20^{\circ} \mathrm{C}$. The impure silane gave a silicon film of $0.7 \mathrm{ohm}-\mathrm{cm}$; the treated silane gave an epitaxial silicon film of $3000 \mathrm{ohm}-\mathrm{cm}$.

10. Schoellner [60] claims in an East German patent that a 50:50 mixture of silane and phosphine, mixed with nitrogen to a phosphine volume \% of 5, was passed through a sodium-magnesium A zeolite and the phosphine was completely removed. The phosphine recovered from the zeolite contained only 0.18 volume $\%$ silane.

11. Caswel1 [61] patented a process to purify silane by means of a synthetic zeolite system to remove arsine and phosphine.

12. In a Russian patent, Lebedev [62] claims purifying silane by passing it through a sorbent of $20 \%-40 \%$ aqueous collodial solution of silica with $1 \%$ ammonia.

13. Yatsurugi et al. [63] in a German patent describe a new ion exchanged zeolite--specifically for removing phosphine from silane. This is a zeolite in which $30 \%-83 \%$ of the ions are replaced by potassium and $16 \%-56 \%$ of the exchangeable calcium is replaced by divalent ions from the group: $\mathrm{Mg}, \mathrm{Zn}, \mathrm{Cd}, \mathrm{Pb}$, and $\mathrm{Mn}$.

14. Kiratoni and Yaisurugi [64] developed a zeolite of fine pore size to purify silane. The sodium of the zeolite is replaced with zinc or lead. In a companion patent [65] they used a lithium ion to replace the sodium. 
15. Takaishi et al. [66] studied the properties of molecular sieves, where the sodium and potassium were replaced with calcium or ziac. The functionality of purifying silanes was measured against their composition.

16. Yusa, Yatsurugi, and Takaishi [67] report that silane made by reacting magnesium silicide and ammonium chloride in ammonia contains diborane, arsine, phosphine, methane, carbon oxides, and nitrogen. A new zeolite with zinc and potassium ions was made from a linde $4 \mathrm{~A}$ molecular sieve. Silane purified with this system gave a deposited silicon of 1000 to 8000 ohm-cm.

17. LeFever [68] states that treating silane with ammonia removed boron hydride and halide impurities. Silane and ammonia are condensed together and heated to $25^{\circ} \mathrm{C}$ at $400 \mathrm{psig}$. The impurities form nonvolatile coordination compounds. The excess ammonia is fractionated or adsorbed at $-78^{\circ} \mathrm{C}$ on synthetic sodium zeolite A. Silicon deposited from this silane had a resistivity of $300 \mathrm{ohm}-\mathrm{cm}$ (less than 5 ppba boron).

18. Tarancon [50] in his 1978 patent details a process for the purification of silane involving passing the impure silane through a succession of six zones connected in series. He lists a typical process silane as having $97 \%-98 \%$ by weight monosilane; $1.5 \%-2.5 \%$ hydrogen, chlnrosilanes, and silicon tetrachloride; $0.5 \%$ helium, silicones, higher silanes, arsine, phosphine, and diborane. This appears to be a silane prepared by the hydride-silicon tetrachloride method. The process is carried out in a closed system to preclude air or moisture. The impure silane is passed through the following zones:

a. A stainless-steel packed column at 8 psig--removes silicon
tetrachloride.

b. Activated charcoal at $-70^{\circ} \mathrm{C}, 7$ psig--removes chlorosilanes and silicones.

c. "Florisil" at $-70^{\circ} \mathrm{C}, 6$ psig--removes arsine and phosphine. (F1orisil is magnesium silicate from the Floridin Company.)

d. Stainless steel packed column at $-24^{\circ} \mathrm{C}, 100$ psig--removes low boilers, gases, and lites.

e. Empty column at $-195^{\circ} \mathrm{C}, 2$ psir--freezes out the silane.

f. Activated charcoal at $20^{\circ} \mathrm{C}, 100$ psig--removes diborane and higher silanes.

Tarancon claims the treated product is $99.99 \%$ pure nonosilane. The product is compressed to 1500 psig for packaging.

19. Hartford [69] and Clark [70] and their coworkers at Los Alamos Laboratories describe a silane purification method based on laserinduced chemistry. By selective photolysis, quantum vields for the. 
destruction of arsine, diborane, and phosphine are claimed. With a 193-nm argon-fluoride excimer laser, at ambient temperature, 50 ppm of arsine and phosphine in silane were reduced to less than $0.5 \mathrm{pmm}$. The impurities were preferentially dissociated and deposited as metal or as polymer on the filters.

20. In a 1965 patent, Bradley [71] claims the purification of chlorosilanes or silane by adding elemental iodine, bromine, or chlorine and distilling. This is said to remove all of the phosphine and arsenic and some of the boron and sulfur. While this technique has been demonstrated with chlorosilanes, its usefulness with silanes would have to be confirmed.

21. Coleman $[72,73]$ reports the preparation of ultra-high-purity silane by using a recycle system in the separation columns. In preparing trichlorosilane for redistribution to silane, he reports that a small amount of silane is fed into the feed system at the stripper column in which chlorosilanes and silicon tetrachloride are separated. The silane at these temperatures reacts with the chloride impurities to form hydrides. Thus, any arsine, phosphine, or boron present as chlorides would be converted to volatile hydrides, which are removed with the other light fragments in the column. This process would be usable only if the investigator were running the total Union Carbide silane process, however (see Section 3.0).

We can conclude that no one process will completely purify silane. On a research level, the use of charcoal, molecular sieves, and perhaps some ammonia traps should yield a fairly pure silane, however, based on the references cited here. Of course, it is desirable to start with the most pure silane available. But note that silane should be handled even at a research level only by experienced personnel. Manufacturers of silane are unanimous in recommending that users not try to purify silane. They suggest that only a filter be used to remove particulate matter. It is suggested that needs for improved silane should be discussed with a supplier. See in particular Tarancon [50]. This patent lists the various filters and the impurities that are removed by each filter. Note that the used filters (saturated with silane) must be properly disposed of. A higher-purity silane may be available by 1984 , both from current suppliers and from the new Union Carbide plant.

\subsection{COMMERCIAL AVAILABILITY}

To determine the commercial status of silanes in the United States, fifteen companies who could make and/or sell them were sent a questionnaire that requested preparation methods, analysis capability, and typical purity, as well as literature, pricing, and grades. This was followed up with one or more telephone calls to confirm data. The comments reported here are those submitted by the companies.

Seven of the U.S. companies contacted indicated they are or can be prime producers of monosilane. It appears that some companies buy some or all of their 
requirements, depending on volume and available supply. The current U.S. companies that produce and sell silane are

- Airco Industrial Gases

- Linde Specialty Gases, Union Carbide Corporation

- Air Products and Chemicals, Inc.

- Liquid Carbonic Corporation

- Matheson Division, Searle Medical Products Corporation

- Scientific Gas Products, Inc.

- Synthatron Corporation.

Allied Chemical Company indicated that it can produce silane and is considering entering the market.

Companies that only sell silane are Ideal Gas Products, Inc., and M. G. Scientific Gases. Disilane is produced and sold by Chronar Corporation (sold by Airco), Matheson Division, and Synthatron Corporation. Several additional companies indicated interest in making disilane, if the market develops. The list of companies contacted and their addresses is given in Appendix G.

No producer was willing to give details on his methods of producing silanes. This is a competitive business and all undoubtedly have their own methods of purifying products. Based on literature, patents, and industry awareness, there are probably three basic processes used commercially to prepare silane:

1. Lithium or sodium hydride with a silicon halide

2. Magnesium silicide with a mineral acid

3. Catalytic redistribution of chlorosilanes.

There are many variations of the processes, but the most often mentioned process in the United States seems to be Method 1. Union Carbide is using Method 3 at their Washington plants.

For disilane, one could use Method 2 above, in which a mixture of silanes usually results. Lithium aluminum chloride with hexachlorodisilane could also be used. A new process involves passing silane through an electrical discharge. This method should produce disilane as pure as the starting silane. Several companies are actively working in this area and could well be developing new methods. We believe that Chronar is using the magnesium silicide process for their production of silane and higher silanes, but is also developing the improved methods for producing a purer disilane. Because disilane can decompose at room temperatures into silane and hydrogen, the material should be analyzed before use.

References are given in the preparation section of this report on the methods for making silanes. Products of all these methods require some purification, however, to improve the quality. Currently, silanes are used in the United States basically in the semiconductor market. Production and sales have been in the millions of grams and distribution has been in gas cylinders. If amorphous silicon solar cell production begins soon, however, larger volumes will 
probably be needed. Scale-up of the hydride or silicide processes could be a problem. The new Union Carbide process should be able to provide bulk silane, if needed, subject to the company's own internal requirements for polysilicon production. The company estimates that it will have the ability to meet any customers' needs, provided that it has adequate lead time.

There are three major grades of silane available: epitaxial, silicon nitride, and charged couple device (CCD). Some companies offer two grades, others offer up to five. Proposed SEMI specifications are given in Appendix D. Epitaxial grades are around $100 \mathrm{ohm}-\mathrm{cm}$. The types over $1000 \mathrm{ohm}-\mathrm{cm}$ are usually of the CCD variety. For silicon nitride, silane is reacted with ammonia; thus, chlorosilane and methane contents should be under $10 \mathrm{ppm}$. Epitaxial grade silane usually allows up to 1000 or $10,000 \mathrm{ppm}$ of chlorosilanes. Most commercial silane today provides n-type epitaxial silicon; that means the phosphorus and arsenic impurities are greater than the boron or aluminum. Other high-resistivity grades are coming on the market; these should be evaluated carefully for solar cells, because impurities are as important as resistivity.

U.S. sales of silane in 1982 were probably over $40,000 \mathrm{~kg}$ or 40 metric tons. This market should follow the semiconductor industry growth curve. In 1983, sales should exceed 45 tons.

\subsubsection{Additional Comments on Silane Producers}

\subsubsection{Airco Industrial Gases}

Airco makes and sells silane and disilane; it may also purchase part of its needs. The company has its own methods of purifying silane made by a lithium hydride-chlorosilane process. It also has a contract with Chronar to distribute disilane and to do quality-control work. They offer nitride-grade silane of $1500 \mathrm{ohm}-\mathrm{cm}$, with the following maximum ppm: oxygen, 1; nitrogen, 25; chlorosilanes, 1; $\mathrm{CO}, 2$; water, 1; argon, 1; hydrogen, 200; methane, 1; and heavy metals, ppt. $1500 \mathrm{ohm}-\mathrm{cm}$ silane is offered at $\$ 1.20 / \mathrm{g}$. Disilane is $\$ 65 / g$ in $25-g$ sizes, $\$ 55 / g$ in $100-g$ sizes.

\subsubsection{Allied Chenical Company}

Allied is not currently producing silane. However, it does have a pilot plant based on the LeFrancois patent (silicon tetrafluoride plus sodium hydride).

\subsubsection{Air Products and Chenicals, Inc.}

Air Products makes and sells silane prepared by the lithium hydride plus silicon tetrachloride method. It offers nitride or epitaxial-grade silane, which equals or exceeds the proposed SEMI specifications, and is greater than $100 \mathrm{ohm}-\mathrm{cm}$. A typical lot would have these ppm impurities: hydrogen, 500; methane, 10-40; $\mathrm{HCl}, 10-20$; $\mathrm{CO}, 5$; nitrogen, 40; rare gas, 40; and water, 1. The company does a complete analysis on each lot, including epitaxial resistivity. It suggests that customers not try to purify silane, but will discuss special needs with them. 


\subsubsection{Chronar Corporation}

Chronar is making silane and disilane basically for its own solar cell production. Excess capacity will be sold through Airco. The quality of the product reported in the Brookhaven data (Section 2.4) was early production. The company reports they have now improved the quality of their products, especially disilane, which is made by a new process.

\subsubsection{Liquid Carbonic Corporation}

The company makes and sells silane, producing it by means of a proprietary process. A 1978 news release states "Liquid Carbonic has been operating the largest silane-producing facility in the U.S. at San Carlos, Ca. They recently completed an expansion which will double plant capacity." Five grades of silane are offered: epitaxial, $100 \mathrm{ohm}-\mathrm{cm}$; polysilicon or oxide grade, 50; silicon nitride, 50; charged couple, 200; and HRS, 400. Typical impurities: hydrocarbons, $10 \mathrm{ppm}, \mathrm{CO}, 10$; hydrogen, 500; and nitrogen, 100 . A special resistivity analysis will be run for $\$ 200$ each. The company recommends only using a filter for particulates.

\subsubsection{Matheson Gas Products, Inc.}

Matheson makes and sells silane and disilane by a proprietary method. It has two grades of silane: semiconductor $-100 \mathrm{ohm}-\mathrm{cm}$, priced from $\$ 0.24$ to $\$ 0.88 / \mathrm{g}$; and Matheson purity, $1000 \mathrm{ohm}-\mathrm{cm}$, priced from $\$ 0.95$ to $\$ 1.30 / \mathrm{g}$. Disilane is sold in 100-g cylinders at $\$ 45 / \mathrm{g}$. Matheson is developing a new process and expects to sell disilane for under $\$ 20$ in 1984. Quality control is basically epitaxial deposition and gas chromatography. The Matheson purity grade has under $10 \mathrm{ppm}$ chlorosilanes. Customers can also request special qualitycontrol tests. The disilane is $99+\%$ pure, with some hydrogen, chlorosilanes, and silane. A new process for disilane is now under development that should yield a purer disilane.

In June 1983, G. D. Searle \& Company announced the sale of its Matheson Gas Products operations in the United States and Canada to a joint venture formed by UGI Corporation's Amerigas subsidiary and Nippon Sanso K. K. of Tokyo. Earlier, Searle announced the sale of its Matheson European operation to Union Carbide Benelux N.V. The U.S. operation will be known as Matheson Gas Products, Inc.

\subsubsection{Scientific Gas Products, Inc.}

This firm makes and sells silane and disilane, using hydrogenation of trichlorosilane. Some material is purchased and purified for sale. They sell two grades of silane: epitaxial, $100 \mathrm{ohm}-\mathrm{cm}$, and nitride grade, $50 \mathrm{ohm}-\mathrm{cm}$. The epitaxial grade has these maximum ppm: nitrogen, 40; oxygen, 10; methane, 40; hydrogen, 1000; water, 3; chlorosilanes, 1000; and rare gases, 40. The nitride grade has the chlorosilanes reduced to $10 \mathrm{ppm}$. Scientific prices silane from $\$ 0.95 / \mathrm{g}$ for $100 \mathrm{~g}$ to $\$ 0.36 / \mathrm{g}$ for $5000 \mathrm{~g}$. It does not suggest that 
the customers try to purify the silane, only that they use a filter to remove any oxide formed in the lines. No special analyses are offered.

\subsubsection{Synthatron Corporation}

Synthatron makes and sells silane and disilane produced by means of a proprietary process and purified by its own technique. It offers several grades of silane; the best grade would have these ppm maximums: nitrogen, 100; oxygen, 1; water, 2; hydrogen, 50; Co, 10; methane, 5; argon, 5; and chlorosilanes, 5. Disilane has this typical profile of impurities: hydrogen, $0.5-1.6 \%$; nitrogen, $50 \mathrm{ppm}$; oxygen, 50; argon, 50; $\mathrm{CO}, 50$; $\mathrm{CO}_{2}, 20$; methane, $10 ; \mathrm{C}_{2} \mathrm{H}_{6}, 10$; chlorides, $0.5 \%$. Complete cylinder analysis costs $\$ 125$. Customers are discouraged from trying to run their own purification processes.

\subsubsection{Union Carbide Corporation, Linde Division}

Linde Specialty Gas Products makes and sells silane prepared by a proprietary method. They offer an electronic grade of 100-150 ohm-cm. Typical impurities are in maximum ppm: chlorosilanes, 50; hydrogen, 200; methane, 50; nitrogen, 100; and some water and oxygen. They will run a special resistivity analysis for $\$ 100$. Linde expects to introduce an "Ultra Plus" grade of silane soon, yielding a deposited film of over $1000 \mathrm{ohm}-\mathrm{cm}$. It recommends that customers not try to purify silane themselves.

\subsubsection{Ideal Gas Products, Inc.}

Ideal sells monosilane and disilane. It gets its silane from Certified Gas and Controls, Inc. Ideal uses a proprietary purification process to make a CCD grade silane, which it calls "thousand-ohm-plus silane," or TOPS. Each lot is evaluated using advanced in-house methods. It also offers an electronic grade, presumably around $100 \mathrm{ohm}-\mathrm{cm}$. The impurity levels in TOPS grade silane were given as 1-5 ppm moisture, 2-5 ppm methane, 20-600 ppm hydrogen, and 5-100 ppm nitrogen. The uncompensated epitaxial deposited silicon can be up to $2500 \mathrm{ohm}-\mathrm{cm}$ resistivity. Spreading conductance measurements can also be taken. Heavy metals are typically less than ppt. Ideal does run the SEMI specification tests and will do custom analysis for customers, sufficient to qualify the silane for its intended use. Disilane is also sold, but the impurities are not listed. Ideal does not suggest further purification by customers, but does suggest that chemically cleaned gas handling equipment be used.

Silane price ranges, as reported by the companies in July 1983, are listed in Table 2-6. These are the list prices, generally for $100-\mathrm{g}$ to $10,000-\mathrm{g}$ or larger cylinders. These prices are for reference only. Customers should get direct quotes for the quality and quantity they need. Disilane is generally available only in 50- or 100-g cylinders. 
Table 2-6. Silane Prices (U.S. 1ist, July 1983)

\begin{tabular}{|c|c|c|}
\hline Company & Grade Name & $\begin{array}{c}\text { Price Range } \\
\quad \text { (\$/gram) }\end{array}$ \\
\hline Airco & $\begin{array}{l}\text { Nitride } \\
\text { CCD } 1500 \\
\text { Disilane }\end{array}$ & $\begin{array}{l}0.32-0.71 \\
1.20-1.50 \\
55.00-65.00\end{array}$ \\
\hline Air Products & $\begin{array}{l}\text { Nitride } \\
\text { Semi conductor }\end{array}$ & $\begin{array}{l}0.50-0.75 \\
0.29-0.90\end{array}$ \\
\hline Linde-UCC & $\begin{array}{l}\text { Semiconductor } \\
\text { Ultra Plusa }\end{array}$ & $\begin{array}{l}0.17-0.41 \\
0.50-1.00\end{array}$ \\
\hline Liquid Carbonic & $\begin{array}{l}\text { Epitaxial } \\
\text { Nitride, CCD } \\
\text { HRS }-400\end{array}$ & $\begin{array}{l}0.16-1.38 \\
0.16-1.30 \\
0.16-1.30\end{array}$ \\
\hline Matheson & $\begin{array}{l}\text { Semiconductor } \\
\text { Matheson Purity } \\
\text { Disilane }\end{array}$ & $\begin{array}{l}0.24-0.88 \\
0.95-1.30 \\
45.00^{b}\end{array}$ \\
\hline Scientific Gas & $\begin{array}{l}\text { Epitaxial } \\
\text { Nitride } \\
\text { VLSi }\end{array}$ & $\begin{array}{l}0.36-0.95 \\
0.43-1.15 \\
1.30-2.78\end{array}$ \\
\hline Synthatron & $\begin{array}{l}\text { Polycrystalline } \\
\text { Epitaxial, Nitride } \\
\text { Disilane }\end{array}$ & $\begin{array}{l}0.30-1.00 \\
0.30-1.00 \\
85.00-130.00\end{array}$ \\
\hline Ideal Gas & $\begin{array}{l}\text { Electronic } \\
\text { TOPS }\end{array}$ & $\begin{array}{l}0.34-0.85 \\
0.61-1.50\end{array}$ \\
\hline
\end{tabular}

available in Fall 1983.

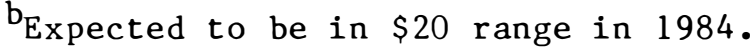

Note: Cylinder sizes of 100, 1000, 3000, and $5000 \mathrm{~g}$ are common, with 10,000, 12,000 , or 16,000-g sizes available from some companies. These are published prices only. Actual prices must be obtained from each company. Note also that there is a cylinder lease or rental charge.

\subsubsection{Silane Data Sheets}

Representative data sheets are attached to this report as Appendix L. This is not intended to be a complete collection of all possible data sheets, however. Sheets are included for the following:

- Airco Industrial Gases

- Air Products silane specifications

- Ideal Gas silane specification and prices

- Linde silane product information sheets

- Liquid Carbonic silane specifications 
- Matheson Tech Brief on high-purity silane

- Matheson disilane

- Scientific Gas Products sheet

- Synthatron specifications.

These sheets should provide an indication of the types of silanes commercially available.

\subsection{REFERENCES}

1. Kuratomi, T.,: and Y. Yatsurugi, Jap. 72 43439, Nov. 8, 1972.

2. Jackson, H. L., Marsh, and Muetterties, Inorgan. Chem., Vo1. 2, 1963, p. 43.

3. Amberger, E., and H. Boeters, Angew. Chem., Vol. 74, 1963, p. 32.

4. Tachiki, K., and Y. Yamashita, Jap. 61 21507, 1961.

5. Sundermeyer, W., USP 078218, Feb. 19, 1963; Ger. 1080077, Apri1 2, 1960.

6. Sundermeyer, W., and L. M. Litz, Chem. Ingr-Tech, Vo1. 37, 1965, pp. 14-18.

7. Litz, L. M., and S. A. Ring, USP 3163590, Dec. 29, 1964.

8. Pavlov, A., and G. Bodyagin, Tr Khim. Khim. Takhnol., Vo1. 2, 1967, pp. 175-78.

9. Franklin, R. B., A. Francis, and G. Tarancon, USP 4041136, Sept. 24, 1976.

10. Komatsu Electronic Metals, Jap. 74 27517, July 18, 1974.

11. Vit, J., et a1., Czech. 126 672, Mar. 15, 1968.

12. Weiss, H. G., and H. D. Fisher, Inorg. Chem., Vol. 2, 1963, pp. 880-81.

13. Bellama, J. M., and A. MacDiarmid, J. Inorgan. Chem., Vo1. 7, 1968, p. 2070 .

14. Finholt, A. E., A. C. Bond, K. E. Wilzbach, and H. I. Schlesinger, J. Am. Chem. Soc., Vol. 57, 1935, pp. 1349-52.

15. Jernejcic, J., J. Skerjane, and M. Smuc, Vesln. Sloven Kem. D. Rusrva, Vol. 2, 1964, pp. 19-23.

16. Norman, A., J. Webster, and W. Jolly, Inorgan. Syn., Vol. 11, 1968, pp. 170-78. 
17. Roy, G., Belgium 830 356, Jan. 4, 1982.

18. Hance, C. R., and G. H. Wagner, USP 2530 367, Nov. 21, 1950.

19. Kato, H., H. Muraoka, and T. Cho, Jap. 74 17517, July 18, 1973.

20. Kuratomi, T., and K. Kawakita, Jap. 73 22917, 1973.

21. Lorenz, J. H., and F. R. Whaley, USP 2912 308, Nov. 10, 1959.

22. Lorenz, J. H., and F. R. Whaley, USP 1915 368, Dec. 1, 1959.

23. Kuratomi, T., and Y. Yatsurugi, Jap. 72 16398, 1972.

24. Kuratomi, T., Jap. 75 17035, June 18, 1975.

25. Tachiki, K., M. Sada, and S. Endo, Jap. 74 98399, Sept. 18, 1974.

26. Stock, A., The Hydrides of Boron and Silicon, Cornell Univ. Press, 1933.

27. Feher, F., et a1., Z. Anorg. Allg. Chemie, Vo1. 385, 1971, pp. 202-8.

28. Johnson, W. C., and T. R. G. Hogness, J. Am. Chem. Soc., Vol. 56, 1934, p. 1252 .

29. Kuratomi, T., and Y. Yatsurugi, USP 3577 220, May 4, 1971.

30. Bakay, C. J., USP 3968 199, July 6, 1976.

31. Littera1, C. J., USP 4113 845, Sept. 12, 1978.

32. Calcote, H. F., Sci. Tech. Aerom. Rep., Vol. 17, 1979, p. 11.

33. Yusa, A., Y. Yatsurugi, and T. Takaishi, J. Electro. Chem. Soc., Vol. 122, 1975, pp. 1700-05.

34. Kutznetsov, A. et a., Zh. Priki khim., Vol. 58, 1978, pp. 1833-36.

35. Isano, M., T. Ohashi, and Y. Shumazaki, Jap. 75 07800, Jan. 27, 1975.

36. Kuratomi, Y., and K. Kawakita, Jap. 74 85000, Aug. 15, 1974.

37. LeFrancois, P. A., Eur Pat. EP 52808, June 2, 1982.

38. Johnson, W. C., and S. Isenberg, J. Am. Chem. Soc., Vol. 57, 1935, pp. 1349-52.

39. Rochow, E. G., Chemistry of Silicon, Pergamon Press, 1975.

40. Stone, F. G. A., Hydrogen Compounds of Group IV Elements, New Yurk: Prentice-Hall, 1962 . 
41. Ebsworth, E., Volatile Silicon Compounds, New York: MacMillan Co., 1963.

42. Gasper, P., C. Levy, and G. Adair, Inorg. Chem., Vol. 9, 1970, pp. 1272-73.

43. JANAF (Joint Army, Navy, Air Force) Thermochemical Tables, Midland, MI: Dow Chemical Co.

44. LeFrancois, P. A., USP 4374111, Feb. 15, 1983.

45. Corderman, R. R., and P. E. Vanier, J. App1. Phys., Vo1. 54, 1983, p. 3987.

46. Corderman, R. R., Brookhaven National Laboratory, personal communication.

47. Carlson, D. E., et al., final report, Amorphous Silicon Solar Cells, 1976-1978, U.S. Dept. of Energy Contract EY 76 C 031286 .

48. Carlson, D. E., et al., SERI Annual Review, Amorphous Materials Subcontractors, Nov. 22-24, 1982, Alexandria, Va.

49. Carlson, D. E., Electronics Packing and Production, Sept. 1978.

50. Tarancon, G., USP 4099 936, July 11, 1978.

51. Chalupa, J., et al., Czech. 101814 , Dec. 15, 1978.

52. Lewis, C. H., et al., J. Electrochem. Soc., Vo1. 108, 1961, pp. 1114-18.

53. Standard Telephone Co. Ltd., Brit. 831 216, Mar. 23, 1960.

54. Caswe11, E. G., and R. A. LeFever, Ger. $1092893,1959$.

55. Netherlands Patent 7803 471, Oct. 20, 1979.

56. 0sano, M., et al., Jap. 75 09598, Jan. 31, 1979.

57. Cowlard, F. C., and R. Kenwright, Brit. 955 663, Apr. 15, 1964.

58. Ohgushi, Y., A. Yusa, K. Kinishita, and Y. Yatsurugi, Bull. Chem. Soc. Jap., Vol. 51, 1978, pp. 419-21.

59. Takaishi, T., and Y. Gomi, Rev. Sci. Instrum., Vol. 47, 1976, pp. 303-5.

60. Shoellner, R., Ger., DD 150559, May 15, 1980.

61. Caswe11, E. G., USP 2971 607, Feb. 14, 1961.

62. Lebedev, E. N., et a1., USSR 812324 , Mar. 15, 1981. 
63. Yatsurugi, Y., T. Kuratomi, and Y. Takaishi, Ger. 2208215 , Oct. 19, 1972.

64. Kuratomi, T., and Y. Yatsurugi, Jap. 73414 37, Dec. 6, 1973.

65. Kuratomi, T., and Y. Yatsurugi, Jap. 73414 39, Dec. 6, 1973.

66. Takaishi, T. K., Y. Yatsurugi, A. Yusa, and T. Kuratomi, J. Chem. Soc. Faraday Trans., Vol. 71, 1975, pp. 97-105.

67. Yusa, A., Y. Yatsurugi, and T. Takaishi, J. Electrochem. Soc., Vol. 122, pp. $1700-05$.

68. LeFever, R. A., Brit. 866 612, Apr. 26, 1961.

69. Hartford, A., Jr., J. Applied Physics, Vol. 51, pp. 4471-74, 1980 .

70. Clark, J., and R. Anderson, Applied Physics Letters, Vol. 32, 1978, pp. 46-9.

71. Bradley, H. B., USP 3188 168, June 8, 1965.

72. Coleman, L. M., USP 4340 574, July 20, 1982.

73. Coleman, L. M., NASA Tech Briefs, Spring/Summer, Vol. 6, No. 41, 1982.

74. Delahoy, E. A., and R. W. Griffith, J. Appl. Phys., Vol. 54 (10), p. 6337,1981 . 


\section{S=Rl}


SECTION 3.0

\section{REVIEW OF THE JPL/UCC CONTRACT--SILANE FOR POLYSILICON PROJECT}

\subsection{INTRODUCT ION}

In 1975, the Jet Propulsion Laboratory (JPL) was selected by the U.S. Government (first by ERDA, and later the Department of Energy) to contract and manage the Low Cost Solar Array Project (LCSA) under the overall renewable energy program. Union Carbide Corporation (UCC) was one of the twelve companies funded to work on less costly methods for making polysilicon. The objective of this contract, No. 954334, was to develop the silane process technology for the manufacture of polysilicon in a large commercial plant in 1986, at a price of not more than $\$ 10 / \mathrm{kg}$ (1975 dollars).

Union Carbide had been interested in silicon chemistry since the 1930s when they began research on silicones. This work was interrupted by World War II assignments on the atomic energy program. Research continued sporadically over the next 30 years and included silane work. UCC produced silane by the trichlorosilane-ethanol process in 1955 and by the molten salt process in 1957. It has continued to be one of the largest current producers of silane. In 1967, UCC's Silicones Division began producing dichlorosilane, using a UCC patented process. Patents were also issued to UCC for producing silane. These processes were used later in the JPL programs.

\subsection{SCOPE OF THE JPL CONTRACT}

The objective of the Phase I program was to conduct feasibility research to establish the practicality of three concepts:

- High-volume, low-cost production of silane, as an intermediate for high purity silicon

- Pyrolysis of silane to silicon in a free space or a fluid bed reactor

- Use of capacitive heating of a fluidized bed.

\section{3 SUMMARY OF THE PROCESS AND DESIGN WORK}

A small process development unit was designed, constructed, and operated in 1975-1977 to demonstrate the conversion of dichlorosilane or trichlorosilane to silane.

Phase II was authorized in 1977, to provide an information base and to do a preliminary design for an experimental process design unit (EPSDU or pilot plant) sized for 100 tons of silicon per year.

Phase III was authorized in 1979 for UCC to design, construct, and operate the EPSDU unit for one year. This program was terminated in 1981, before any of the purchased equipment could be assembled. Union Carbide then negotiared 
with the Department of Energy to obtain this equipment in order to complete the silane part of the unit with corporate funds. They then moved the EPSDU equipment from the East Chicago site to another company location at Washougal, Washington. This unit is now part of the Electronics Division Materials Technical Center at that location. Government funding continued in 1983 on Phase IV, with limited work on fluid bed decomposition of silane.

In the fall of 1980, Union Carbide Corporation approved the construction of a 1000-metric ton plant to produce polysilicon from silane. The technology needed to decompose silane was purchased from the Komatsu Electronic Metals Company, Ltd, a subsidiary of Komatsu, Ltd. Engineering studies were begun in 1981; ground was broken at the Moses Lake, Washington, site on July 6, 1982; and initial production is scheduled for late 1984.

\subsection{DESCRIPTION OF THE SILANE PROCESS}

A simplified flow schematic for the overall process to make silane and polysilicon is shown in Figure $3-1$. This process converts $98 \%$ metallurgical grade silicon to trichlorosilane (TCS) in a hot fluid bed reactor fluidized with a hot, equimolar hydrogen/silicon tetrachloride (STC) gas feed. The hot vapor product from the reactor, which contains $15 \%$ trichlorosilane, is quench-cooled to its dew point to reject heavy metal chloride contaminants. The product is fed to a stripping column which frees the liquid of dissolved gases. In the TCS distillation column, the liquid is separated into silicon tetrachloride for recycling and an overhead product of trichlorosilane and lites. The overhead product is further processed in a second distillation column to separate trichlorosilane off the bottom. The trichlorosilane is recycled to the first distillation column through a catalyst in the redistribution reactor that partially converts it to silicon tetrachloride and dichlorosilane. Overhead product from the second distillation column, dichlorosilane and lites, is fed through another catalytic redistribution reactor, which partially converts it to silane. The silane mixture is processed through the final silane polishing column.

Ninety-eight percent pure, powdered metallurgical grade silicon, with an average particle size of 300 microns, is fed from a storage bin to a catalyst blender (see Figure 3-2). A small amount of copper catalyst can be added here. This mixture is fed into the fluid bed, hydrogenation reactor, operating at some $482^{\circ} \mathrm{C}$ and 500 psia. A recycle stream of hydrogen and silicon tetrachloride, in equimolar parts, is preheated to over $510^{\circ} \mathrm{C}$ before entering the reactor. Make-up hydrogen is added from the pyrolysis reactor or from a storage tank. The hot vapor product contains some $15 \% \mathrm{TCS}, 44 \%$ hydrogen, $41 \%$ STC, and some silicon dust. All of the trace metal contaminants from the feed silicon are also present as metal chlorides. This is quenched and moved to a settler tank. Many of the metal contaminants settle out as insoluble compounds. A small stream is bled off the bottom of the settler to remove these solids. Hydrogen is removed and recycled to the hydrogenation reactor. The crude TCS/STC is moved to a storage tank. 


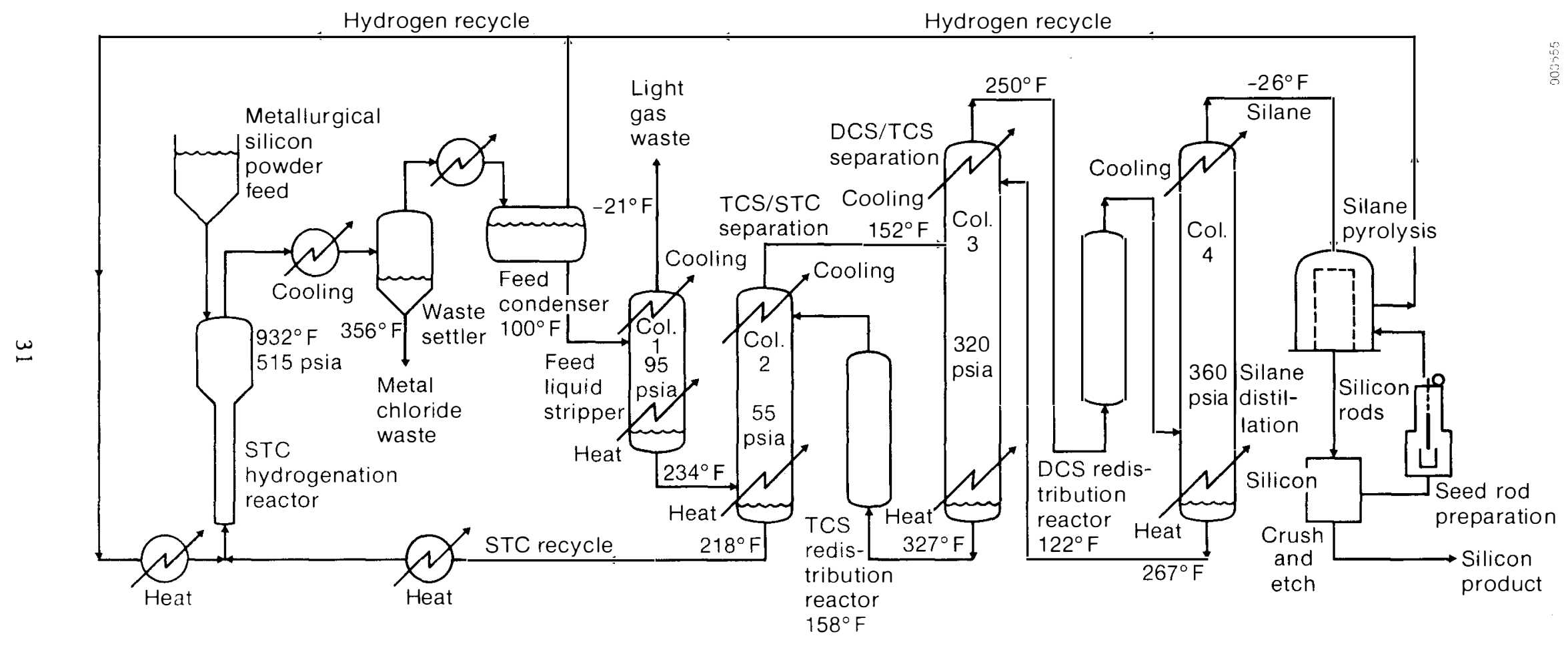

Source: Final report, Low Cost Solar Array Project, JPL/UCC Contract No. $954334,1979$.

Figure 3-1. Flow Schematic of the Union Carbide Silane Process, Ultra-High-Purity Silicon Plant 


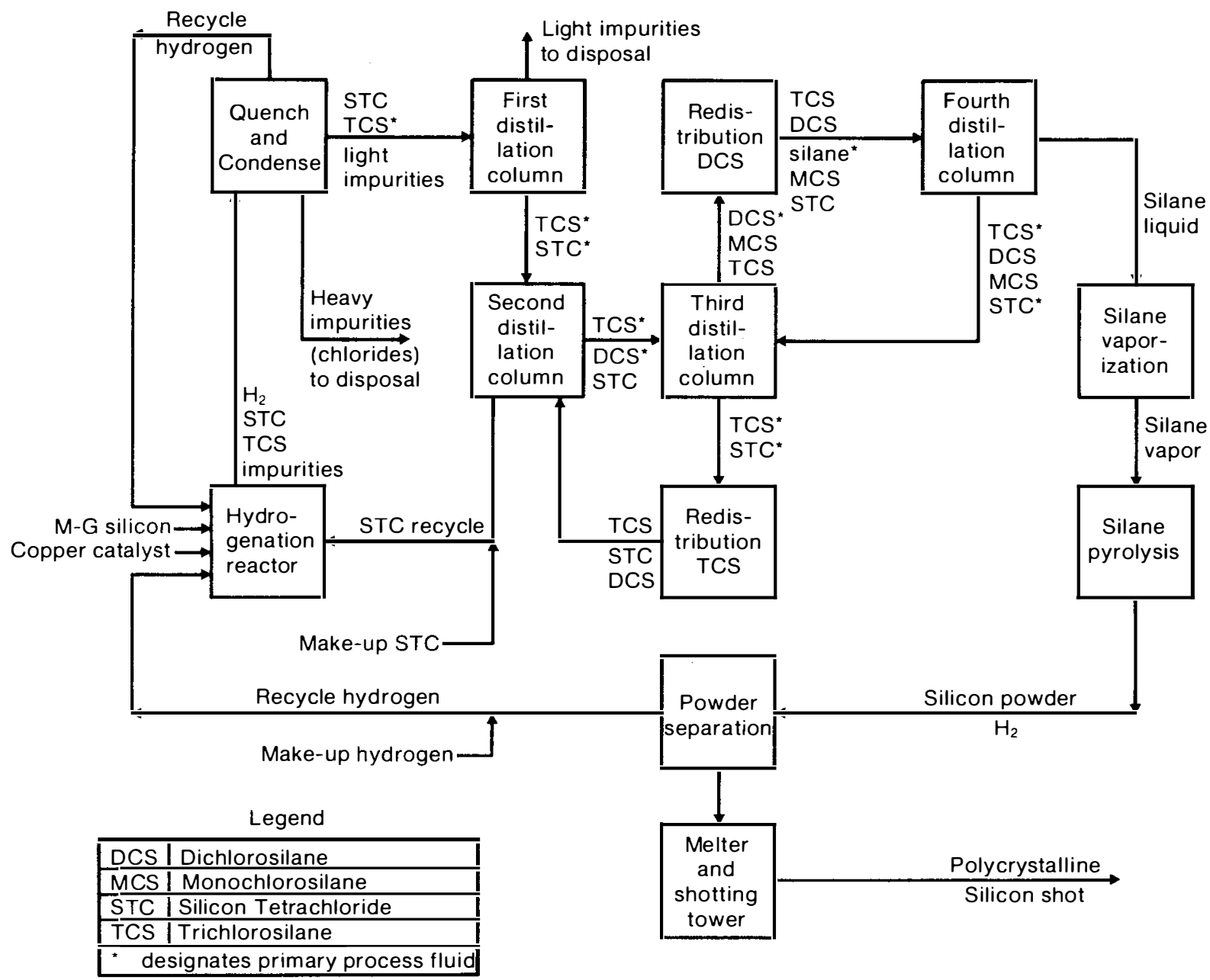

Source: Final report, Flat Plate Solar Array Project, JPL/UCC Contract No. 954334, 1981 .

Figure 3-2. Block Flow Diagran of the Silane-Silicon Process 
The crude TCS/STC mixture is then fed to a stripper colnm to retrove al. volatile contaminant gases lighter than silane to at least $0.01 \mathrm{ppb}$ and to remove $99 \%$ of the heavy volatile contaminants. The crude rCS/STC is fed to the second column, which also receives a recycle stream from the first redistribution reactor. This column should separate $97 \%$ of the TCS overhead and reject $97 \%$ of the STC as bottom liquid for recycling.

The trace metal contaminants-- $\mathrm{PCl}_{3}, \mathrm{AsCl}_{3}, \mathrm{FeCl}_{3}, \mathrm{NiCl}_{2}, \mathrm{CuCl}_{2}$, and $\mathrm{CaCl}_{2}--$ have a higher boiling point than the TCS and thus will be rejected with the STC and eventually removed as sludge from the settler tank. If any of these metals are present as hydrides, they will still be with the TCS.

The TCS, which also has monochlorosilane and dichlorosilane (DCS) with it, is fed into the third column, along with a second feed from the recycle of the silane column. This is set to deliver $97 \%$ of the TCS to the bottom and $97 \%$ of the DCS to the top as distillate. The bottom product is cooled and fed through a Rohm and Haas Amberlyst $A-21$ amine base ion exchange resin in the catalytic redistribution reactor. This reactor catalyzes the following reactions:

$$
\begin{aligned}
& 2 \mathrm{HSiCl}_{3}=\mathrm{H}_{2} \mathrm{SiCl}_{2}+\mathrm{SiCl}_{4} \\
& 2 \mathrm{H}_{2} \mathrm{SiCl}_{2}=\mathrm{H}_{3} \mathrm{SiCl}+\mathrm{HSiCl}_{3} \\
& 2 \mathrm{H}_{3} \mathrm{SiCl}=\mathrm{SiH}_{4}+\mathrm{H}_{2} \mathrm{SiCl}_{2} .
\end{aligned}
$$

The DCS is cooled and passed into a second redistribution reactor similar to the first. This product is fed into the fourth column, which separates out some 11 mol \% silane. The silane product is stored as liquid for evaluation, cylindering, or to supply the pyrolysis reactors.

\subsection{CALCULATED PROCESS IMPUR ITIES}

The primary source of impurities is the metallurgical silicon raw material. Other impurities could enter with the copper catalyst, hydrogen, nitrogen, or silicon tetrachloride. The amounts of impurities possible and their sources and exit points in the process are shown in Table 3-1. The boiling points of the various possible compounds in the stream are listed in Table 3-2. These data indicate that separation by distillation should be possible.

Theoretical calculations suggest a possible silane purity of less than $0.05 \mathrm{ppb}$ of the Group III or Group V elements, with some hydrogen. This is based on the process operating continuously at equilibrium.

\subsection{SPECIAL PURIFICAT ION PROCESSES}

In the process, there are redundant purification techniques to ensure the purity of the silane product. Three of these techniques have been feat:1red in the NASA Tech Briefs (Purification Section 24). Copies of these briefs are attached as Appendices H, I, and J. 
Table 3-1. Process Impurities for Union Carbide Silane

\begin{tabular}{|c|c|c|c|c|c|c|c|c|}
\hline \multirow{2}{*}{$\begin{array}{l}\text { Element or } \\
\text { Compound }\end{array}$} & \multicolumn{2}{|c|}{$\begin{array}{l}\text { Amount Entering } \\
\text { per Amount Product }\end{array}$} & \multicolumn{4}{|c|}{$\begin{array}{l}\text { Entry Point, Percentage } \\
\text { of Total Compound Entering }\end{array}$} & \multicolumn{2}{|c|}{$\begin{array}{c}\text { Exit Point (' } \mathrm{X} \text { ' } \\
\text { indicates compound } \\
\text { is present) }\end{array}$} \\
\hline & 1b. moles & s/1b. mole & $\begin{array}{l}\text { Metal Grade } \\
\text { Silicon }\end{array}$ & $\begin{array}{l}\text { Cement } \\
\text { Copper }\end{array}$ & Hydrogen & STC & $\begin{array}{l}\text { Waste } \\
\text { Chlorides }\end{array}$ & $\begin{array}{l}\text { Stripper } \\
\text { Column }\end{array}$ \\
\hline Alumi num & 3.25 & $\times 10^{-3}$ & $96.5 \%$ & $1.1 \%$ & -- & $2.5 \%$ & $\mathrm{x}$ & \\
\hline Antimony & 2.63 & $\times 10^{-6}$ & 81.0 & 16.2 & - & 2.8 & $\mathrm{x}$ & \\
\hline Argon & 6.43 & $\times 10^{-5 a}$ & 0.4 & -- & 99.6 & - & & $x$ \\
\hline Arsenic & 4.19 & $\times 10^{-6}$ & 81.0 & 16.2 & - & 2.8 & $\mathrm{X}$ & $\mathrm{X}$ \\
\hline Boron & 1.01 & $\times 10^{-4}$ & 100.0 & -- & $\ldots$ & $<0.1$ & $\mathrm{x}$ & $\mathrm{x}$ \\
\hline Calcium & 4.68 & $\times 10^{-4}$ & 100.0 & $-\infty$ & $-\infty$ & - & $\mathrm{x}$ & \\
\hline Carbon (C) & 1.3 & $\times 10^{-3}$ & 100.0 & - & -- & - & $\mathrm{x}$ & \\
\hline Carbon Dioxide & 2.42 & $\times 10^{-6}$ & 0.3 & -- & 99.7 & -- & & $x$ \\
\hline Chromi um & 1.20 & $\times 10^{-4}$ & 100.0 & -- & - & -- & $\mathrm{X}$ & \\
\hline Copper & 9.60 & $\times 10^{-3}$ & 0.6 & 99.4 & -- & $<0.1$ & $\mathrm{X}$ & \\
\hline Helium & 6.05 & $\times 10^{-5}$ & - & -- & 100.0 & - & & $\mathrm{X}$ \\
\hline Iron & 3.10 & $\times 10^{-3}$ & 99.9 & 0.1 & - & $<0.1$ & $\mathrm{X}$ & \\
\hline Lead & 4.2961 & $\times 10^{-6}$ & 25.2 & 74.0 & -- & 0.8 & $\mathrm{x}$ & \\
\hline Magnesium & 2.16 & $\times 10^{-4}$ & 99.2 & 0.8 & -- & - & $\mathrm{X}$ & \\
\hline Manganese & 1.14 & $\times 10^{-4}$ & 100.0 & - & -- & $<0.1$ & $\mathrm{x}$ & \\
\hline Methane & 1.94 & $\times 10^{-6}$ & 0.7 & -- & 99.3 & - & & $x$ \\
\hline $\mathrm{Me}_{2} \mathrm{SiCl}_{2}$ & 9.678 & $\times 10^{-4 b}$ & - & -- & $\ldots$ & 100.0 & & $\mathrm{X}$ \\
\hline Nickel 2 & 3.96 & $\times 10^{-5}$ & 100.0 & - & -- & $<0.1$ & $\mathrm{X}$ & $\mathrm{X}$ \\
\hline Nit rogen $\left(\mathrm{N}_{2}\right)$ & 2.01 & $\times 10^{-2 c}$ & 6.2 & -- & 0.2 & 93.6 & & $\mathrm{X}$ \\
\hline Oxygen $\left(0_{2}\right)^{2}$ & 4.18 & $\times 10^{-3 d}$ & 59.7 & 39.3 & 0.7 & 0.3 & $\mathrm{X}$ & \\
\hline Phosphorus & 2.01 & $\times 10^{-4}$ & 100.0 & -- & -- & $<0.1$ & $\mathrm{X}$ & $\mathrm{X}$ \\
\hline Sulfur & 7.19 & $\times 10^{-5}$ & 7.0 & 93.0 & -- & -- & $\mathrm{X}$ & $\mathrm{X}$ \\
\hline Titanium & 2.21 & $\times 10^{-4}$ & 83.9 & - & $\ldots$ & 16.1 & $\mathrm{X}$ & \\
\hline Vanadian & 1.22 & $\times 10^{-4}$ & 99.4 & -- & -- & 0.6 & $\mathrm{X}$ & \\
\hline Zinc & 4.81 & $\times 10^{-6}$ & 100.0 & - & -- & $-\infty$ & $\mathrm{X}$ & \\
\hline Zirconium & 8.25 & $\times 10^{-5}$ & 77.7 & -- & -- & 22.3 & $\mathrm{X}$ & \\
\hline
\end{tabular}

aArgon does not include pyrolysis purge quantities.

bypical organic-chlorosilane. Decomposes to methane and chlorosilanes.

c Includes dissolved nitrogen in inert gas padding on STC storage tanks.

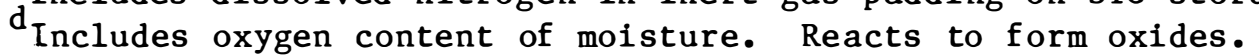

Source: Final report, Low Cost Solar Array Project, JPL/UCC Contract No. 954334, 1979. 
Table 3-2. Union Carbide Silane Process Compound Relative Volatility Factor

\begin{tabular}{llc}
\hline \multicolumn{1}{c}{ Compound } & Formula & $\begin{array}{c}\text { Normal Boiling } \\
\text { Point }\left({ }^{\circ} \mathrm{C}\right)\end{array}$ \\
\hline Arsenic chloride & $\mathrm{AsCl}_{3}$ & 130 \\
Arsenic hydride & $\mathrm{AsH}_{3}$ & -55 \\
Boron chloride & $\mathrm{BCl}_{3}$ & +12.5 \\
Boron hydride & $\mathrm{B}_{2} \mathrm{H}_{6}$ & -96.5 \\
Phosphorous chloride & $\mathrm{PCl}_{3}$ & +76 \\
Phosphorous hydride & $\mathrm{PH}_{3}$ & -85 \\
Hydrogen sulfide & $\mathrm{H}_{2} \mathrm{~S}_{2}$ & -60 \\
Silane & $\mathrm{SiH}_{4}$ & -112 \\
Monochlorosilane & $\mathrm{H}_{3} \mathrm{SiCl}_{1}$ & -30.4 \\
Dichlorosilane & $\mathrm{H}_{2} \mathrm{SiCl}_{2}$ & +8.6 \\
Trichlorosilane & $\mathrm{HSiCl}_{3}$ & +31.8 \\
Silicon tetrachloride & $\mathrm{SiCl}_{4}$ & +56.7 \\
\hline
\end{tabular}

Source: Final report, Low Cost Solar Array Project, JPL/UCC Contract No. 954334, 1979.

\subsubsection{Controlled Distillation}

It is possible that certain contaminants of intermediate volatility could become trapped in sections of the distillation system. For example, $\mathrm{BCl}_{3}$, whose boiling point falls between those of DCS and TCS, will go with the overhead distillate product in the TCS column, enter the DCS column, and be rejected to the bottom products. Thus, it is possible that the concentration of $\mathrm{BCl}_{3}$ could build up in the system and carry over into the product. To prevent this, small bleed streams are designed in the system to provide an exit path from the system. Thus, the closed-loop process can be operated for maximum economies of conservation of chlorine, hydrogen, and minimum waste disposal (see Appendix H).

\subsubsection{Converting Metal Chlorides to Volatile Hydrides}

When the crude products from the hydrogenation reactor are run through the stripper to remove most of the silicon tetrachloride for recycling and to vent off the light waste gases, impurities such as arsenic, phosphorus, and boron chlorides would stay with the TCS cut. These would impose a heavier load on the downstream processing equipment. A new patent, issued in 1982, presents the techn:que used in the UCC process. A small amount of silane is fed into the bottom of the stripper column. The silane reacts with the Group III and $V$ chlorides to form hydrides of arsenic, boron, and phosphorus. These volatile compounds are readily removed with the light gas wastes. Only 10 to $100 \mathrm{ppm}$ of silane need to be diverted from the final silane column to the stripper to convert the 1 to $10 \mathrm{ppm}$ of impurity chlorides (see Appendix I). 


\subsubsection{Use of Multi-Passes through the Catalytic Redistribution Reactors}

The resin catalyst used in these reactors is functionally a tertiary aliphatic amine. Any boron compound that travelled this $f a r$ in the process stream should form a complex with the amine and be removed. The continuous-flow, closed-loop system provides several passes through the equipment (see Appendix J).

\subsubsection{Final Distillation}

The final distillation column is keyed to remove any boron hydride which has survived all the other traps. Diborane boils at $-93^{\circ} \mathrm{C}$, while silane boils at $-112^{\circ} \mathrm{C}$. The column can be operated to produce a silane product with less than $0.01 \mathrm{ppb}$ diborane, even if the column feed contains up to $5 \mathrm{ppm}$.

\subsection{COMERCIAL AVAILABILITY}

The Union Carbide Washougal plant was started up in early 1983. It is expected that it will make silane available to be marketed by the Linde Division by the Fall of 1983.

While complete analyses of the silane have not been run, we can calculate a derived purity from the analysis of the deposited layer of polysilicon. Polysilicon produced in March of 1983 at Washougal was analyzed as follows: boron, 0.021 ppba; phosphorus, 0.065 ppba; and arsenic, antimony, and aluminum below the detection limit of $0.01 \mathrm{ppba}$. These data equate to the following amounts of these materials in the starting silane: boron, 0.07 ppbw; and phosphorus, $0.063 \mathrm{ppbw}$. The lifetime test on the polysilicon was over 6000 microseconds; this indicates very few, if any, heavy metal impurities. This polysilicon had a resistivity of $2000 \mathrm{ohm}-\mathrm{cm}$, n-type. Unfortunately, no direct relationship of the reading on polysilicon versus the deposited epitaxial layer of silicon has been established. The preliminary analysis on silane from the UCC Washougal plant indicates only hydrogen and argon present in measurable quantities. UCC indicates that in steady-state equilibrium production, these gases should be stripped out.

The pricing for this type of silane has not been established yet, but it is expected to be in the range of the currently available $1000 \mathrm{ohm}-\mathrm{cm}$ or better silanes $(\$ 0.50$ to $\$ 2.50 / \mathrm{g})$.

\subsection{BIBLIOGBAPHY}

Breneman, W. C., E. G. Ferrier, and H. Morihara, "Preliminary Process Design and Economics of Low Cost Solar Grade Silicon Production," Proceedings of the 13th Institute of Electrical and Electronics Engineers Photovoltaic Conference, Washington, D.C., Jan. 5, 1978.

Coleman, L. M., and W. C. Breneman, USP 4340 574, July 20, 1982. 
Jet Propulsion Laboratory, "Proceedings of the Flat Plate Solar Array Wrkshon in the Science of Silicon Material Preparation," JPL publication No. 83-13, Feb. 1983.

NASA Tech Briefs, Spring/Summer 1982, Vol. 6, No. 4, Items 23, 24, 25.

Union Carbide Corporation, "Feasibility of the Silane Process for Producing Semiconductor Grade Silicon," Final report, June 1979, Contract No. 954334, Jet Propulsion Laboratory/U.S. Department of Energy.

Union Carbide Corporation, Final Report--Phase III, Contract No. 954334, Jet Propulsion Laboratory/U.S. Department of Energy (unpublished). 


\section{SEPI}




\section{SECT ION 4.0}

\section{SILANE AND DISILANE IN JAPAN}

\subsection{MARKET SUMMARY}

Until 1981, silane was used in Japan mostly for semiconductors--deposits of epitaxial silicon, silicon oxide, or silicon nitride. Most of this silane was sold as $1 \%$ to $20 \%$ mixtures with inert gases. There was only one domestic producer, Komatsu. Union Carbide Corporation and Matheson also sold U.S.produced silane in the Japanese market.

The methods of doing business in Japan are similar to those in the United States but sometimes they may seem a little more complicated. There are producers, importers, traders, distributors, resellers, and agents. Any one importer or distributor might sell through several agents or dealers. No Japanese company currently exports silane to the United States.

The Japanese government's "Sunshine Project," their photovoltaic program, has closely focused on the use of amorphous silicon solar cells. These cells are now in commercial production in Japan. This has already attracted more local producers and off-shore interest in the market.

It is estimated that the silane market in Japan in 1981 was some $8,000 \mathrm{~kg}$ ( 8 metric tons). In 1982, this grew to an estimated $13,000 \mathrm{~kg}$. Komatsu had the major share of the market, which it shared with imported Union Carbide and Matheson silane. Prices seem to range from $\$ 0.20$ to $\$ 0.30 / g$, which is comparable to U.S. prices.

\subsection{COMAKRCIAL AVAILABILITY}

\subsubsection{Manufacturers of Silane in Japan}

Three companies now manufacture silane in Japan: Komatsu Electronic Metals Company, Ltd.; Mitsui Toatsu Chemicals, Inc.; and Honjo Chemicals Corporation.

Komatsu Electronic Metals Co., Ltd.

2612 Shinomiya, Hiratsuka

Kanagawa Ken, 254, Japan

Komatsu has made silane for over 15 years. The industry rates it as capable of making up to 60 tons of silane, mostly for their own use in making polysilicon. Its many patents and publications (referenced in the report sections on preparation and purification) testify to its interest in the area. These publications refer chiefly to the company's preparation method of reacting magnesium silicide with ammonium chloride in liquid ammonia. Komatsu's data sheet, Appendix $\mathrm{K}$, indicates that silane has a very low boron content and a minimum of other contaminants. Its deposited silicon films yield a resistivity of more than 2,000 ohm $-\mathrm{cm}$. Being the only producer of silane in Japan 
up to 1982, Konacsu had most of the merchant market there. One could expect that it will hold that market share as the volume expands, and very likely expand production as needed.

The Honjo Chemical Corporation

3-18-21, Nishinakajima

Yodogawa-ku, Osaka

532 Japan

Honjo started production of silane in 1982, with a license from Matheson. Its capacity is estimated at three tons per year. No data were given in its response, but one could expect the product to be of the same quality as Matheson's in the United States.

Mitsui Toatsu Chemicals, Inc.

2,5 Kasumigaseki 3-chome

Chiyodaku, Tokyo

100 Japan

Mitsui started up a plant capable of making five tons per year of silane early in 1983. Its process has not yet been disclosed. Product data sheets will be available later this year.

\subsubsection{Traders or Sellers of Silane}

The following companies act as wholesalers for local producers and/or import silane. They might also repackage or dilute it with other gases, as needed.

Nippon Sanso (Komatsu distributor)

16-7 Nisni-Shimbashi 1-chome

Minatoku, Tokyo

105 Japan

Takachiho Trading (Matheson importer)

4-8 Hiroo 1-chome

Shi buyaku, Tokyo

150 Japan

Seitetsu Kagaku (Union Carbide importer)

22, 5-chome Kitahama

Higashiku, Osaka

541 Japan

Nissan Shoji

Kozatokaikan

Nishishinbashi, Minatoku

Tokyo, 105, Japan

Tomoe Shokai

1-25 Minimikamata 1-chome

Otaku, Tokyo

144 Japan 
Suzuki Shokan

1, Kojimachi 3-chome

Chi yodaku, Tokyo

100 Japan

Toyoko Kagaku

1280 Nakamaruko

Nakaharaku, Kawasakishi

Kanagawaken, 211 Japan

\subsection{DISILANE}

There is no commercial production of disilane in Japan, as of the end of 1982. Several companies are in the pilot-plant stage; these include Shin Etsu, Mitsui Toatsu, and possibly Honjo. Only small amounts of disilane are imported. Prices of the imported disilane are in the $\$ 100 / \mathrm{g}$ range. Mitsui indicated it would have small quantities of disilane available in 1984, at prices (in Japan) of $\$ 5 / g$ or less. Purity data are not available.

\subsection{COMMENTS}

The announcement in June 1983 of the sale of the Matheson Gas Products operation to a joint venture formed by the Amerigas subsidiary of the UGI Corporation and Nippon Sanso K. K. of Tokyo, is expected to have an impact on the Japanese silane situation. Nippon Sanso could easily now use the Matheson technology to make silanes in Japan. Nippon Sanso has been repackaging Komatsu silane and selling it through at least six dealers.

On August 8, 1983, Air Products and Chemicals announced that they had acquired a minority interest in Daido Oxygen Co. Air Products also signed a technology exchange with this Japanese industrial gas concern. This move could have an impact on the silane industry in Japan.

\subsection{BIBLIOGRAPHY}

Dr. K. Isogaya, Mitsui Toatsu Chemicals, Inc., private communication. Japan Economic News, 1982 issues.

Dr. M. Kobayashi, Honjo Chemical Company, private communication. 


\section{SEPI}


SECTION 5.0

\section{CONCLUS IONS}

Silane has been available over the past 20 years in quality and quantities tailored to meet the requirements of the semiconductor industry, which consumed some $40,000 \mathrm{~kg}$ in 1982. This market will continue to grow at $12 \%$ $18 \% / \mathrm{yr}$. The advent of large-scale integrated circuits stimulated the search for better quality materials, including silane. So, to meet this demand, higher purity silanes have become available in the past few years.

Production capacity for silane has generally kept pace with need. In 1983, silane capacity in the United States was over $55,000 \mathrm{~kg}$ (50 tons). In addition, a new Union Carbide polysilicon plant started in 1983 has the capacity to make $120,000 \mathrm{~kg} / \mathrm{yr}$ of silane. In Japan, the 13,000-kg silane market is supplied by three domestic producers along with imported material from four U.S. and European firms. Therefore, current and planned capacity will be adequate to serve new and existing markets.

\subsection{SILANE}

Seven U.S. producers of silane each offer two or more grades. The original epitaxial-grade silane had a deposited silicon film of 50-150 ohm-cm. New special grades have epitaxial films of 500 to a reported $10,000 \mathrm{ohm}-\mathrm{cm}$. Most U.S. silane is made from chlorosilanes and alkali metal hydride; therefore, chlorosilane, $\mathrm{HCl}$, siloxanes, carbon oxides, and hydrocarbons are common impurities. The electronic grades sell for $\$ 0.17 / \mathrm{g}$, and Premium grades cost $\$ 0.50$ to $\$ 2.00 / \mathrm{g}$ in large volumes. New process work under way at several firms could result in further improvements in quality and cost. For example, silane from the new Union Carbide process contained only parts-per-billion impurities, according to the firm's analyses.

\subsection{DISILANE}

Disilane, available only in research quantities from three U.S. producers, is made from the processes described in this report, which yield mixed higher silanes and chloride contaminants. Purification, however, is not easy. The advantages of using disilane are known, but its quality, uniformity, and price must improve to make it suitable for wider use. Recently, several companies have revealed that new production processes are being developed. These could involve making disilane by passing silane through an electrical discharge, a method that should yield a much purer disilane.

Disilane prices have ranged from $\$ 45$ to $\$ 85 / \mathrm{g}$ in $100-\mathrm{g}$ cylinders. One company indicates that its new process could result in a higher purity disilane at $\$ 20 / g$ in 1984. The impact of larger disilane markets on future prices is very hard to predict at this time. 


\subsection{JAPAN}

In Japan, silane for both semiconductor and solar cell uses has been supplied by Komatsu and by imported naterial from three off-shore firms. Prices and quality have been similar to those in the United States. As silane is used more and more in the production of amorphous solar cells, two additional Japaneses firms have now begun producing it. Moreover, two U.S. companies that make silane have recently joined forces with Japanese partners. This all suggests that much more competitive marketing will occur in the future.

Three Japanese firms are now developing processes in order to enter the disilane market. One company said that they expect to be able to sell their disilane in Japan for less than $\$ 5.00 / \mathrm{g}$. No quality data are available, however. No silanes are currently being exported from Japan, but one company has indicated that it is surveying possible U.S. markets.

\subsection{GENERAL COMMENTS}

At the beginning of this study, we hoped that a simple, single-step purification procedure for silane might be uncovered. Unfortunately, there does not seem to be such a process. Procedures do exist, however, for removing one or two contaminants from silane in one step. All current producers of silane advise customers not to attempt to purify it, and we concur with this suggestion.

With the projected availability of new grades of silane and the new Union Carbide process for silane, the solar industry will have materials to evaluate that are more pure than previous ones. One aspect yet to be accomplished is the development of a solar specification for silane and disilane. In order to specify limits for boron, phosphorus, and heavy metals, analytical procedures will have to be developed.

Improved silanes are now coming into the market, and increased competition is expected to keep prices at fair values. 
APPENDIX A

TYPICAL PROCESS SILANE COMPOSITION

Monosilane: $97 \%-98 \%$.

Hydrogen, chlorosilanes, silicon tetrachloride: $1.5 \%-2.5 \%$.

Higher silanes, arsine, phosphine, diborane: $0.5 \%$.

( $1 \%$ equals 10,000 ppm.)

The source of this analysis is Tarancon, U.S. Patent 4099 936, July 11, 1978. This is believed to be the lithium-chlorosilane process, the most popular silane process in the United States.

Note: The material contained in these appendices is presented for information only; none of it represents endorsement of a particular product or process by the author, the Solar Energy Research Institute, or the U.S. Dept. of Energy. 
APPENDIX B

MMPURITIES IN METALLURGICAL-GRADE SILICON

For $98 \%$ silicone-grade silicon:

\begin{tabular}{lcr}
\hline Element & Maximum $\%$ & Ppm \\
\hline $\mathrm{Al}$ & 0.20 & 2000 \\
$\mathrm{Fe}$ & 0.60 & 6000 \\
$\mathrm{Ca}$ & 0.10 & 1000 \\
$\mathrm{Mn}$ & 0.06 & 600 \\
$\mathrm{Cr}$ & 0.03 & 300 \\
$\mathrm{As}$ & 0.005 & 50 \\
$\mathrm{~B}$ & 0.005 & 50 \\
$\mathrm{Bi}$ & 0.005 & 50 \\
$\mathrm{C}$ & 0.05 & 500 \\
$\mathrm{Cb}$ & 0.05 & 500 \\
$\mathrm{Co}$ & 0.01 & 100 \\
$\mathrm{Cu}$ & 0.01 & 100 \\
$\mathrm{Mo}$ & 0.01 & 100 \\
$\mathrm{Ni}$ & 0.01 & 100 \\
$\mathrm{P}$ & 0.01 & 100 \\
$\mathrm{~Pb}$ & 0.003 & 30 \\
$\mathrm{~S}$ & 0.01 & 100 \\
$\mathrm{Sb}$ & 0.005 & 50 \\
$\mathrm{Sn}$ & 0.005 & 50 \\
$\mathrm{Ta}$ & 0.01 & 100 \\
$\mathrm{Ti}$ & 0.04 & 400 \\
$\mathrm{~W}$ & 0.01 & 100 \\
$\mathrm{~V}$ & 0.02 & 200 \\
$\mathrm{Zn}$ & 0.005 & 50 \\
$\mathrm{Zr}$ & 0.02 & 200 \\
\hline $\mathrm{Th}$ & $\mathrm{y}$ & $\mathrm{sh}$ \\
\hline
\end{tabular}

The source of this table is the Elkem Metals Company data sheet, 1982. Silicon is produced from North Carolina quarzite, low ash coal, petroleum coke, and wood chips in an electric furnace with carbon electrodes. 


\section{APPENDIX C \\ SILICON TETRACHLORIDE SOURCES AND POSS IBLE IMPUR ITIFS}

\section{Production Methods}

A. Direct production. Fumed silica producers, usually captive use: DeGussa, Cabot.

B. Zirconium producers: Teledyne, Western Zirconium.

C. Trichlorosilane producers: Union Carbide, Dow Corning, Texas Instruments, General Electric.

D. Effluent from the TCS/polysilicon plants: Monsanto, Motorola, Texas Instruments, General Electric.

E. Direct merchant producer: Van de Mark.

\section{Possible Impurities}

A. All metal chlorides of elements found in metallurgical-grade silicon.

B. All metal chlorides of elements in zirconium ores.

C. Variable--could be B, P, As, in ppb levels; $C$ in ppm; and $S$ in ppm. If shipped in drums, Fe and higher levels of the above elements could be present.

D. B in ppm, P, As in ppm, C in ppm, and higher chlorosilanes (polymers).

E. Distilled product--ppm of all elements in A.

Note: Specially distilled and purified silicon tetrachloride is available for epitaxial use at $\$ 2$ to $\$ 4$ per pound. 


\title{
APPENDIX D
}

PROPOSED SEMI STANDARDS FOR SILANE*

\section{SEMI Standard C3.STD.9 for Silane Specification (SiH4) for Polysilicon and/or Silicon Dioxide Application (Proposed)}

Purity: $98.8897 \%$

Resistivity: $>50 \mathrm{ohm}-\mathrm{cm}$ n-type

Impurities

Maximum Acceptable Level (ppm)

Oxygen $\left(\mathrm{O}_{2}\right)$

Water $\left(\mathrm{H}_{2} \mathrm{O}\right)$

Hydrogen $\left(\mathrm{H}_{2}\right)$

Total of carbon dioxide + carbon monoxide $\left(\mathrm{CO}_{2}+\mathrm{CO}\right)$

Total hydrocarbons expressed as methane

$$
\begin{array}{r}
10 \\
3 \\
10,000 \\
10 \\
40 \\
1,000 \\
40 \\
a \\
a
\end{array}
$$

Chlorosilane (ionizable chlorides including

$\mathrm{HCl}$ reported as $\mathrm{Cl}$ )

Rare

Heavy metals

Particulates

11,103

TOTAL IMPURITIES

\begin{abstract}
a To be determined between supplier and user.
Note: Percent purity may include trace quantities of nitrogen.

Notice: SEMI makes no warranties or representations as to the suitability of the standards set forth herein for any particular application. The determination of the suitability of the standard is solely the responsibility of the user. Users are cautioned to refer to manufacturer's instructions, product labels, product data sheets, and other relevant literature respecting any materials mentioned herein. These standards are subject to change without notice.
\end{abstract}

*Adapted from the Semiconductor Equipment and Materials Institute (SEMI) specifications, August 1981. 
SEMI Standard C3.STD.10 for Silane Specification (SiH 4 ) for Silicon Nitride Application (Proposed)

Purity: $99.9417 \%$

Resistivity: $>50 \mathrm{ohm}-\mathrm{cm}$ n-type

Impurities

Maximum Acceptable Level (ppm)

Oxygen $\left(\mathrm{O}_{2}\right)$

Water $\left(\mathrm{H}_{2} \mathrm{O}\right)$

10

Hydrogen $\left(\mathrm{H}_{2}\right)$

3

Total of carbon dioxide + carbon monoxide $\left(\mathrm{CO}_{2}+\mathrm{CO}\right)$

otal hydrocarbons expressed as methane

Chlorosilane (ionizable chlorides including

$\mathrm{HCl}$ reported as $\mathrm{Cl}$

Rare

10

Heavy metals

40

Particulates

a

TOTAL IMPURITIES

583

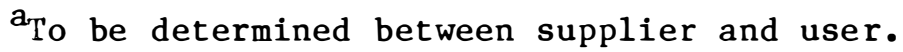

Note: Percent purity may include trace quantities of nitrogen.

Notice: SEMI makes no warranties or representations as to the suitability of the standards set forth herein for any particular application. The determination of the suitability of the standard is solely the responsibility of the user. Users are cautioned to refer to manufacturer's instructions, product labels, product data sheets, and other relevant literature respecting any materials mentioned herein. These standards are subject to change without notice. 


\section{SEMI Standard C3.STD.11 for Silicon Tetrachloride Specification $\left(\mathrm{SiCl}_{4}\right)$ (Proposed)}

\begin{tabular}{lll}
\hline Assay: & $99.59 \%$ minimum by weight \\
Dopants: & $\begin{array}{l}\text { Acceptor } \\
\text { Donor }\end{array}$ & $0.3 \mathrm{ppba}$ \\
& $>1.5 \mathrm{ppba}$ \\
\hline Resistivity: & $>100$ ohm-cm (n-type) \\
& $>1000$ ohm-cm (p-type) \\
\hline Trichlorosilanes: & $0.4 \%$ (1iquid phase) \\
& $<100 \mathrm{ppm}$ (1iquid phase)
\end{tabular}

Notice: SEMI makes no warranties or representations as to the suitability of the standards set forth herein for any particular application. The determination of the suitability of the standard is solely the responsibility of the user. Users are cautioned to refer to manufacturer's instructions, product labels, product data sheets, and other relevant literature respecting any materials mentioned herein. These standards are subject to change without notice. 
SEMI Standard C3.STD.10 for Silane Specification $\left(\mathrm{SiH}_{4}\right)$ for Silicon Nitride Application (Proposed)

Purity: $\quad 99.9417 \%$

Resistivity: $>50$ ohm-cm n-type

Impurities

Oxygen $\left(\mathrm{O}_{2}\right)$

Water $\left(\mathrm{H}_{2} \mathrm{O}\right)$

Hydrogen $\left(\mathrm{H}_{2}\right)$

Total of carbon dioxide + carbon monoxide $\left(\mathrm{CO}_{2}+\mathrm{CO}\right)$

Total hydrocarbons expressed as methane

Chlorosilane (ionizable chlorides including

$\mathrm{HCl}$ reported as $\mathrm{Cl}$ )

Rare

Heavy metals

Particulates

Maximum Acceptable Level (ppm)

10

3

500

10

10

10

40

a

a

TOTAL IMPURITIES

583

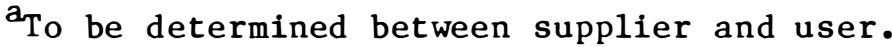

Note: Percent purity may include trace quantities of nitrogen.

Notice: SEMI makes no warranties or representations as to the suitability of the standards set forth herein for any particular application. The determination of the suitability of the standard is solely the responsibility of the user. Users are cautioned to refer to manufacturer's instructions, product labels, product data sheets, and other relevant literature respecting any materials mentioned herein. These standards are subject to change without notice. 


\section{APPENDIX E}

PHYSICAL PROPERTIES OF SILANES

\begin{tabular}{lcccc}
\hline & $\mathrm{SiH}_{4}$ & $\mathrm{Si}_{2} \mathrm{H}_{6}$ & $\mathrm{Si}_{3} \mathrm{H}_{8}$ & $\mathrm{Si}_{4}{ }^{\mathrm{H}} 10$ \\
\hline Melting point $\left({ }^{\circ} \mathrm{C}\right)$ & -185 & -132.5 & -117.4 & -84.3 \\
Boiling point $\left({ }^{\circ} \mathrm{C}\right)$ & -111.9 & -14.5 & 52.9 & 107.4 \\
$\begin{array}{l}\text { Vapor pressure } \\
0{ }^{\circ} \mathrm{C}\end{array}$ & -- & -55 & 9.1 \\
$-118{ }^{\circ} \mathrm{C}$ & 53 & 1 & -- & 249 \\
Critical temp. $\left({ }^{\circ} \mathrm{C}\right)$ & -3.5 & 109 & 189 & 0.79 \\
$\begin{array}{l}\text { Density of liquid } \\
\text { at } 1 \text { atm g/mL }\end{array}$ & 0.68 & 0.69 & 0.725 & \\
\hline
\end{tabular}

Data from he Chemistry of Silicon, Rochow [39]. 
APPENDIX F

DATA ON UNION CARBIDE MOLECULAR SIEVES

UNION CARBIDE CORPORATION LINDE DIVISION

National Specialty Gases Office

Department HGR

100 Davidson Avenue-Box 444

Somerset, N.J. 08873

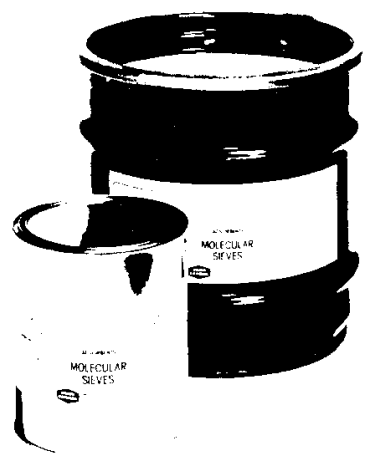

\section{Molecular Sieves}

The first commercial quantities of UNION CARBIDE Molecu lar Sieves became available in 1954 - the result of Union Carbide's research with natural zeolites which began in 1948

UNION CARBIDE Molecular Sieves are synthetically produced, crystalline metal alumino-silicates, that have been activated for adsorption by removing their water of hydration. Since little or no change of structure occurs during this dehydration, unusual, highly porous adsorbents are formed that have a strong af finity for water and certain other gases and liquids.

Unlike other adsorbents, Molecular Sieves have a precise, uniform size and molecular dimension. According to the size of these pores, molecules may be readily adsorbed, slowly adsorbed or completely excluded.

This sieve-like selectivity, based on molecular size, plus a selective preference for polar or polarizable molecules, gives Molecular Sieves an extremely high level of adsorption efficiency, and permits close tailoring of the adsorbent to the specific use. Molecular Sieves have a basic formula of $\mathrm{M}_{2} / \mathrm{n}$ $\mathrm{O} \cdot \mathrm{Al}_{2} \mathrm{O}_{3} \cdot \times \mathrm{SiO}_{2}, \mathrm{yH}_{2} \mathrm{O}$ where $\mathrm{M}$ is a cation of $\mathrm{n}$ valence. They are completely different from the gel-type amorphous alum ino-silicates commonly referred to as zeolites, which although similar in composition, do not exhibit any selectivity based on molecular size.

Through its pioneer synthesis techniques in adsorption technology, Union Carbide has been able to produce and evaluate numerous types of synthetic zeolites, differing in chemical composition, crystal structure and adsorption properties.

UNION CARBIDE Molecular Sieves are produced in a wider range and type than any other adsorbents. They are available in the form of powder, beads or pellets. Among those which have been found to be more commercially useful are Type $4 \mathrm{~A}$ and Type $13 \mathrm{X}$ which have the following unit cell formulas

Type $4 \mathrm{~A}-\mathrm{Na}_{12}\left[\left(\mathrm{AlO}_{2}\right)_{12}\left(\mathrm{SiO}_{2}\right)_{12}\right] \cdot 27 \mathrm{H}_{2} \mathrm{O}$

Type $13 \mathrm{X}-\mathrm{Na}_{86}\left[\left(\mathrm{AlO}_{22}\right)_{86}\left(\mathrm{SiO}_{2}\right)_{106}\right] \cdot 276 \mathrm{H}_{2} \mathrm{O}$

In both cases the sodium ion can be exchanged to form other useful products.

This catalog lists UNION CARBIDE Molecular Sieves that have the widest range of commercial use. Technical and application information for each of these is available upon request. Many less commonly used sieves for specialized applications, although not listed, are also available. Inquiries should be sen to the Union Carbide Specialty Gases Office listed on the back cover. 


\section{Adsorbents • Molecular Sieves}

\begin{tabular}{|c|c|c|c|c|}
\hline & $\begin{array}{c}\text { Part } \\
\text { Number }\end{array}$ & Quantity & Description & Price \\
\hline $\begin{array}{l}\text { Type 3A } \\
\text { UNION CARBIDE } \\
\text { Molecular Sieves } \\
\text { Form: Powder and pellets } \\
\text { Nominat Pore Diameter: } 3 \dot{A}\end{array}$ & $\begin{array}{l}\text { MS-1001 } \\
\text { MS-1002 } \\
\text { MS-1003 } \\
\text { MS-1004 } \\
\text { MS-1005 } \\
\text { MS-1006 }\end{array}$ & $\begin{array}{l}\frac{1 / 2}{\mathrm{lb}} \\
1 / 2 \mathrm{lb}-\text { Case of } 6 \\
2 \mathrm{lb} \\
2 \mathrm{lb}-\text { Case of } 4 \\
12 \mathrm{lb} \\
30 \mathrm{lb}\end{array}$ & $\begin{array}{l}\text { Powder } \\
\text { Powder } \\
\text { Powder } \\
\text { Powder } \\
\text { Powder } \\
\text { Powder }\end{array}$ & $\begin{array}{r}\$ 1100 \\
5600 \\
2000 \\
6800 \\
7500 \\
14200\end{array}$ \\
\hline $\begin{array}{l}\text { Molecules Excluded: }>3 \dot{A} \\
\quad \text { effective diameter. } \\
\text { e.g., ethane } \\
\text { Base: Alumına-Sıficate } \\
\text { Cation. Potassium } \\
\text { Heat of Adsorption (max.): }\end{array}$ & $\begin{array}{l}\text { MS- } 1014 \\
\text { MS-1015 } \\
\text { MS-1016 } \\
\text { MS-1017 } \\
\text { MS-1018 } \\
\text { MS-1019 } \\
\text { MS-1020 }\end{array}$ & $\begin{array}{l}1 \mathrm{lb} \\
1 \mathrm{lb}-\text { - Case of } 6 \\
5 \mathrm{lb} \\
5 \mathrm{lb}-\text { - Case of } 4 \\
25 \mathrm{lb} \\
25 \mathrm{lb} \text {.. Case of } 4 \\
50 \mathrm{lb}\end{array}$ & $\begin{array}{l}1 / 16 \text {-in. Pellets } \\
1 / 16 \text {-in. Pellets } \\
1 / 16 \text {-in. Pellets } \\
1 / 16 \text {-in. Pellets } \\
1 / 16 \text {-in. Pellets } \\
1 / 16 \text { - in. Pellets } \\
1 / 16 \text { - in. Pellets }\end{array}$ & $\begin{array}{r}13.00 \\
66.00 \\
3800 \\
121.00 \\
13500 \\
412.00 \\
202.00\end{array}$ \\
\hline $\begin{array}{l}1800 \text { Biu/lb } \mathrm{H}_{2} \mathrm{O} \\
\text { Application: } \\
\text { The preferred Molecular Sieve } \\
\text { adsorbent for the commercial } \\
\text { dehydration of unsaturated } \\
\text { hydrocarbon streams such as } \\
\text { cracked gas, propylene, butadiene } \\
\text { and acetylene. It is also used for } \\
\text { drying polar liquids such as } \\
\text { methanol and ethanol }\end{array}$ & $\begin{array}{l}\text { MS }-1028 \\
\text { MS }-1029 \\
\text { MS } 1030 \\
\text { MS- } 1031 \\
\text { MS }-1032 \\
\text { MS } 1033 \\
\text { MS } 1034\end{array}$ & $\begin{array}{l}1 \mathrm{lb} \\
1 \mathrm{lb}-\text { Case of } 6 \\
5 \mathrm{lb} \\
5 \mathrm{lb}-\text { Case of } 4 \\
25 \mathrm{lb} \\
25 \mathrm{lb}-\text { - Case of } 4 \\
50 \mathrm{lb}\end{array}$ & $\begin{array}{l}1 / 8 \text {-in. Pellets } \\
1 / x \text {-in. Pellets } \\
1 / 8 \text {-in. Pellets } \\
1 / 8 \text {-in. Pellets } \\
1 / 8 \text {-in. Pellets } \\
1 / 8 \text {-in Pellets } \\
1 / 8 \text { in Pellets }\end{array}$ & $\begin{array}{r}13.00 \\
66.00 \\
3800 \\
121.00 \\
135.00 \\
412.00 \\
20200\end{array}$ \\
\hline $\begin{array}{l}\text { Type 4A } \\
\text { UNION CARBIDE } \\
\text { Molecular Sieves } \\
\text { Form: Powder, pellets, mesh and beads } \\
\text { Nominal Pore Diameter: } 4 \AA\end{array}$ & $\begin{array}{l}\text { MS-1069 } \\
\text { MS-1070 } \\
\text { MS-1071 } \\
\text { MS-1072 } \\
\text { MS-1073 } \\
\text { MS-1074 }\end{array}$ & $\begin{array}{l}\frac{1}{2} \mathrm{lb} \\
1 / 2 \mathrm{lb}-\text { Case of } 6 \\
2 \mathrm{lb} \\
2 \mathrm{lb}-\text { Case of } 4 \\
12 \mathrm{lb} \\
30 \mathrm{lb}\end{array}$ & $\begin{array}{l}\text { Powder } \\
\text { Powder } \\
\text { Powder } \\
\text { Powder } \\
\text { Powder } \\
\text { Powder }\end{array}$ & $\begin{array}{r}\$ 1100 \\
5600 \\
2000 \\
6800 \\
7500 \\
14200\end{array}$ \\
\hline $\begin{array}{l}\text { Molecules Excluded: }>4 \AA \\
\text { effective diameter, e.g., propane } \\
\text { Base: Alumına-Silicate } \\
\text { Cation: Sodium } \\
\text { Heat of Adsorption (max.1: } \\
\quad 1800 \mathrm{Btu} / \mathrm{lb} \mathrm{H}_{2} \mathrm{O}\end{array}$ & $\begin{array}{l}\text { MS-1082 } \\
\text { MS-1083 } \\
\text { MS-1084 } \\
\text { MS-1085 } \\
\text { MS-1086 } \\
\text { MS-1087 } \\
\text { MS-1088 }\end{array}$ & $\begin{array}{l}1 \mathrm{lb} \\
1 \mathrm{lb}-\text { Case of } 6 \\
5 \mathrm{lb} \\
5 \mathrm{lb}-\text { Case of } 4 \\
25 \mathrm{lb} \\
25 \mathrm{lb}-\text { Case of } 4 \\
50 \mathrm{lb}\end{array}$ & $\begin{array}{l}1 / 16 \text {-in. Peilets } \\
1 / 16 \text { - in. Pellets } \\
1 / 16 \text { - in. Pellets } \\
1 / 16 \text { - in. Pellets } \\
1 / 16 \text { - in. Pellets } \\
1 / 16 \text { - in. Pellets } \\
1 / 16 \text { - in. Pellets }\end{array}$ & $\begin{array}{r}1300 \\
66.20 \\
3800 \\
12100 \\
135.00 \\
41200 \\
202.00\end{array}$ \\
\hline $\begin{array}{l}\text { Application: } \\
\text { The preferred Molecular Sieve adsorbent } \\
\text { for static dehydration in a closed gas or } \\
\text { liquid system. It is used as a static } \\
\text { desiccant in household refrigeration } \\
\text { systems, in packaging of drugs, in } \\
\text { electronic components, in perishable } \\
\text { chemicals and as a water scavenger }\end{array}$ & $\begin{array}{l}\text { MS-1096 } \\
\text { MS-1097 } \\
\text { MS-1098 } \\
\text { MS-1C99 } \\
\text { MS-1 100 } \\
\text { MS-1 101 } \\
\text { MS-1102 }\end{array}$ & $\begin{array}{l}1 \mathrm{lb} \\
1 \mathrm{lb}-\text { Case of } 6 \\
5 \mathrm{lb} \\
5 \mathrm{lb}-\text { Case of } 4 \\
25 \mathrm{lb} \\
25 \mathrm{lb}-\text { - Case of } 4 \\
50 \mathrm{lb}\end{array}$ & $\begin{array}{l}1 / 8 \text {-in. Pellets } \\
1 / 8 \text {-in. Pellets } \\
1 / 8 \text {-in. Pellets } \\
1 / 8 \text {-in. Pellets } \\
1 / 8 \text {-in. Pellets } \\
1 / 8 \text {-in. Pellets } \\
1 / 8 \text {-in. Pellets }\end{array}$ & $\begin{array}{r}1300 \\
6600 \\
3300 \\
12100 \\
13500 \\
41200 \\
20200\end{array}$ \\
\hline $\begin{array}{l}\text { in paint and plastic systems. } \\
\text { Also used commercially in drying } \\
\text { saturated hydrocarbon streams. } \\
\text { Molecular Sieves with Indicator are } \\
\text { beads that have been chemically } \\
\text { impregnated to display a blue color } \\
\text { when fully activated by removing } \\
\text { the water of hydration. When a gas }\end{array}$ & $\begin{array}{l}\text { MS- } 11110 \\
\text { MS-1111 } \\
\text { MS-1112 } \\
\text { MS-1113 } \\
\text { MS-1114 } \\
\text { MS-1115 } \\
\text { MS-1116 }\end{array}$ & $\begin{array}{l}1 \mathrm{lb} \\
1 \mathrm{lb}-\text { Case of } 6 \\
5 \mathrm{lb} \\
5 \mathrm{lb}-\text { Case of } 4 \\
25 \mathrm{lb} \\
25 \mathrm{lb}-\text { Case of } 4 \\
50 \mathrm{lb}\end{array}$ & $\begin{array}{l}14 \times 30 \text { Mesh } \\
14 \times 30 \text { Mesh } \\
14 \times 30 \text { Mesh } \\
14 \times 30 \text { Mesh } \\
14 \times 30 \text { Mesh } \\
14 \times 30 \text { Mesh } \\
14 \times 30 \text { Mesh }\end{array}$ & $\begin{array}{r}\$ 1300 \\
6600 \\
3800 \\
12100 \\
13500 \\
41200 \\
20200\end{array}$ \\
\hline
\end{tabular}




\begin{tabular}{|c|c|c|c|c|}
\hline & $\begin{array}{c}\text { Part } \\
\text { Number }\end{array}$ & Quantity & Description & Price \\
\hline \multicolumn{5}{|l|}{ Type 4A (Continued) } \\
\hline \multirow{3}{*}{$\begin{array}{l}\text { UNION CARBIDE } \\
\text { Molecular Sieves }\end{array}$} & MS-1124 & $1 \mathrm{lb}$ & $8 \times 12$ Beads & $\$ 1300$ \\
\hline & MS-1125 & $1 \mathrm{lb}$ - Case of 6 & $8 \times 12$ Beads & 6600 \\
\hline & MS 1126 & $5 \mathrm{lb}$ & $8 \times 12$ Beads & 3800 \\
\hline \multirow{16}{*}{$\begin{array}{l}\text { Stream is dried using this product. the } \\
\text { blue color will turn to pink as water is } \\
\text { adsorbed denoting saturation ot the } \\
\text { sleve The sieve may then be reac } \\
\text { tivated at } 200^{\circ} \mathrm{C} \text { under vacuum or } \\
\text { nitrogen atmosphere for several hours. } \\
\text { More conveniently, the sieve may be } \\
\text { replaced from fresh stock. See page } \\
170 \text { of this catalog tor a low-pressure } \\
\text { molecular sieve gas purifier column } \\
\text { that may be used with this product or } \\
\text { any of the other molecuiar sieve types. }\end{array}$} & MS-1127 & $5 \mathrm{lb}-$ Case of 4 & $8: \times 12$ Beads & 12100 \\
\hline & MS 11128 & $25 \mathrm{lb}$ & $8 \times 12$ Beads & 13500 \\
\hline & MS 1129 & $25 \mathrm{lb}$ - Case of 4 & $8 \times 12$ Beads & 91200 \\
\hline & MS- -1130 & $50 \mathrm{lb}$ & $8 \times 12$ Beads & 20200 \\
\hline & MS. 1138 & $\mathrm{llb}$ & $4 \times 8$ Beads & 1300 \\
\hline & MS-1139 & $1 \mathrm{lb}$ - Case of 6 & $4 \times 8$ Beads & 6600 \\
\hline & MS. 1140 & $5 \mathrm{lb}$ & $4 \times 8$ Beads & 3800 \\
\hline & MS-1141 & $5 \mathrm{lb}-$ Case of 4 & $4 \times 8$ Beads & 12100 \\
\hline & MS.1142 & $25 \mathrm{lb}$ & $4 \times 8$ Beads & 1350 \\
\hline & MS 1143 & 25 it - Case of 4 & $4 \times 8$ Beads & 412.00 \\
\hline & MS-1144 & $50 \mathrm{lb}$ & $4 \times 8$ Beads & 20200 \\
\hline & MS. 1152 & $1 \mathrm{lb}$ & $8 \times 12$ Beads $w / 1$ ndicator & 2000 \\
\hline & MS-1153 & $1 \mathrm{lb}$ - Case of 6 & $8 \times 12$ Beads w/Indicator & 105.00 \\
\hline & MS. 1154 & $5 \mathrm{lb}$ & $\mathrm{B} \times 12$ Beads w/indicator & $700 !$ \\
\hline & MS.1155 & $5 \mathrm{lb}-$ Case of 4 & $8 \times 12 \mathrm{Beadsw} /$ Indicator & 24300 \\
\hline & MS- 1156 & $25 \mathrm{lb}$ & $8 \times 12$ Beads w/Indicator & $2: 000$ \\
\hline \multirow{2}{*}{\multicolumn{5}{|c|}{ Type 5A }} \\
\hline \multirow{3}{*}{$\begin{array}{l}\text { UNION CARBIDE } \\
\text { Molecular Sieves }\end{array}$} & MS. 1179 & $1 / 2 \mathrm{lb}$ & & $\$ 1100$ \\
\hline & MS 1180 & $1 / 2$ b Case of 6 & Powder & 5,00 \\
\hline & MS 1181 & $2 \mathrm{lb}$ & Powder & 2000 \\
\hline \multirow[t]{2}{*}{ Form: Powder and pellets } & MS 1182 & $2 \mathrm{lb}$ Case of 4 & Powder & 6800 \\
\hline & MS. 1183 & $12 \mathrm{lb}$ & Powder & 7500 \\
\hline Nominal Pore Diameter: $5 \dot{A}$ & MS 1184 & $30 \mathrm{lb}$ & Powder & 14200 \\
\hline \multirow{4}{*}{$\begin{array}{l}\text { Molecules Excluded: }>5 \check{A} \\
\text { effective diameter. } \\
\text { e.g., iso compounds and } \\
\text { all four carbon rings }\end{array}$} & MS-1192 & $11 \mathrm{t}$ & $1 / 16$-in. Pellets & $: 300$ \\
\hline & MS-1193 & 1 1 b Case of 6 & $1 / 16$ in Pellets & 6500 \\
\hline & MS 1194 & $5 \mathrm{lb}$ & $1 / 16$ in Pellets & 3800 \\
\hline & MS.1195 & $5 \mathrm{lb}$... Case of 4 & $1 / 16$ in Pellets & 12100 \\
\hline \multirow{2}{*}{ Base: Alumina-Silicate } & MS-1 196 & $25 \mathrm{lb}$ & $1 / 16$ in Pellets & 13500 \\
\hline & MS.1197 & $25 \mathrm{lb}$.- Case of 4 & $1 / 16$-in. Pellets & 41200 \\
\hline Cation: Calcium & MS 1198 & $50 \mathrm{Ib}$ & $1 / 16 \cdot$ in . Pellets & 20200 \\
\hline \multirow{2}{*}{$\begin{array}{l}\text { Heat of Adsorption (max.): } \\
\quad 1800 \mathrm{Btu} / \mathrm{lb} \mathrm{H}_{2} \mathrm{O}\end{array}$} & MS 1206 & $1 \mathrm{lb}$ & $1 / 8$-in. Pellets & $: 300$ \\
\hline & MS. 1207 & $1 \mathrm{lb}$ - Case of 6 & $1 / \%$ in. Pellets & $6 r 5.00$ \\
\hline \multirow{5}{*}{$\begin{array}{l}\text { Application: } \\
\text { Separates normal paraffins } \\
\text { from branchedechain and } \\
\text { cyclic hydrocatons through } \\
\text { a selective adsorption process. }\end{array}$} & MS 1208 & $5 \mathrm{lb}$ & $1 / 8$. in Pellets & 3800 \\
\hline & MS. 1209 & 5 tb - Case of 4 & $1 / 8$.in. Pellets & 12100 \\
\hline & MS 1210 & $25 \mathrm{lb}$ & $1 / 8$ in. Pellets & 1850 \\
\hline & MS. 1211 & $25 \mathrm{lb}$. Case of 4 & $1 / 8$-in, Pellets & $\because 200$ \\
\hline & MS.1212 & $50 \mathrm{lb}$ & $1 / 8$-in. Pellets & 20200 \\
\hline \multirow{5}{*}{$\begin{array}{l}\text { Type AW-300 } \\
\text { UNION CARBIDE } \\
\text { Molecular Sieves } \\
\text { Form: Pellets }\end{array}$} & MS- 1042 & $1 \mathrm{lb}$ & $1 / 16$ in. Pellets & 1300 \\
\hline & MS-1043 & $1 \mathrm{lb}-$ Case of 6 & $1 / 16$ in. Pellets & 66.00 \\
\hline & MS- 1044 & $5 \mathrm{tb}$ & $1 / 16$-in, Pellets & 38.00 \\
\hline & MS-1045 & $5 \mathrm{lb}-$ Case of 4 & $1 / 16$-in Pellets & $12: 00$ \\
\hline & MS. 1046 & $25 \mathrm{lb}$ & $1 / 16$-in Pellets & 1.3500 \\
\hline \multirow{2}{*}{ Nominal Pore Diameter: $4 \hat{\AA}$} & $M S \cdot 1047$ & 25 ib - Case of 4 & $1 / 16 \cdot$ in . Pellets & 41200 \\
\hline & MS-1048 & $50 \mathrm{lb}$ & $1 / 16$-in Pellets & 20200 \\
\hline Molecules Excluded: $4 \AA$ & MS-1056 & $1 \mathrm{lb}$ & $1 / 8 \cdot$ in. Pellets & 1300 \\
\hline \multirow{2}{*}{ Base: Alumina-Silicate } & MS. 1057 & $1 \mathrm{lb}$. Case of 6 & $1 / 8$-in. Pellets & 6600 \\
\hline & MS-1058 & $5 \mathrm{lb}$ & $1 / 8$. in Peliets & 360 \\
\hline \multirow{4}{*}{$\begin{array}{l}\text { Application: } \\
\text { Dehydration of trace acid- } \\
\text { containing streams and ion } \\
\text { exchange. }\end{array}$} & MS-1059 & $5 \mathrm{lb}-$ Case of 4 & $1 / 8$ - In Pellets & 12170 \\
\hline & MS-1060 & $25 \mathrm{lb}$ & $1 / 8$. in Pellets & i $35(6)$ \\
\hline & MS.1061 & $25 \mathrm{lb}$.- Case of 4 & $1 / 8$-in. Pellets & 11? 00 \\
\hline & MS. 1062 & $50 \mathrm{lb}$ & $1 / 8$ - In Pellers & $20 ? 00$ \\
\hline
\end{tabular}




\section{Adsorbents • Molecular Sieves}

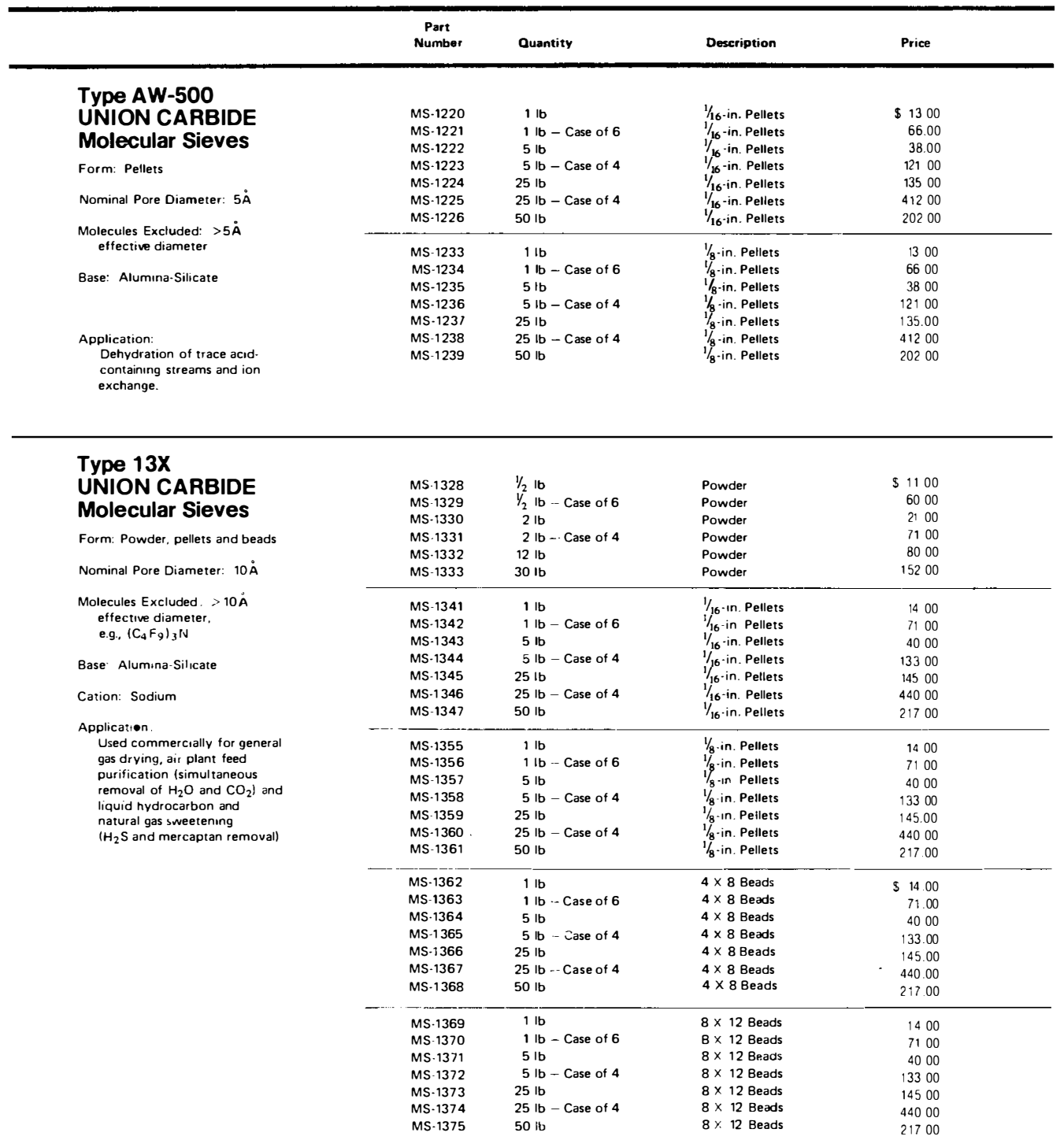




\section{APPENDIX G}

\section{LIST OF U.S. COMPANIES CONTACTED}

\section{Producers and Sellers:}

Airco Industrial Gases

575 Mountain Avenue Murray Hil1, NJ 07974

(201) 464-8100

Air Products and Chemicals, Inc.

P. 0. Box 1104

Allentown, PA 18105

(215) 481-8257

Robert Welch, Product Manager

Liquid Carbonic Corporation

135 S. LaSalle St reet

Chicago, IL 60603

Dr. W. G. Lee, National Account Manager

(312) 855-2500

Chronar Corporation

P. 0. Box 177

Princeton, NJ 08540

(609) 587-8000

Dr. Allen Delahoy

Allied Chemical

P. 0. Box 1087R

Morristown, NJ 07960

(201) 455-2000

J. H. F. Loozen, Manager, New Business Development

Matheson Gas Products

30 Seaview Drive

Secaucus, NJ 07094

Frank Sconavacca, V.P., Marketing

(201) 867-4100

Scientific Gas Products, Inc.

2330 Hamilton B1vd.

S. Plainfield, NJ 07080

(201) 754-7700

Synthatron Corporation

50 Intervale Road

Parsippany, NJ 07054

(201) 335-5000

Paul Mann, National Sales Manager 
Union Carbide Corporation

Linde Specialty Gas Products

P. 0. Box 444

100 Davidson Avenue

Somerset, NJ 08873

(201) 356-8000

Steve A. Conviser, Business Manager

Pat Taylor, Product Manager

\section{Sellers Only:}

Ideal Gas Products Inc.

977 New Durham Road

Edison, NJ 08817

(201) 287-8766

H. G. Gill, Chairman

M. G. Scientific Gases

M. G. Burdett Gas Products

175 Meister Avenue

N. Branch, NJ 08876

(201) 321-9595 


\section{APPENDIX H}

NASA TECH BRIEF:

PURIFY ING SILANE

\section{Eliminating Impurity Traps in the Silane Process}

The extraction of a small slipstream from separators prevents impurities from building up

NASA's Jet Propulsion Laboratory, Pasadena, California

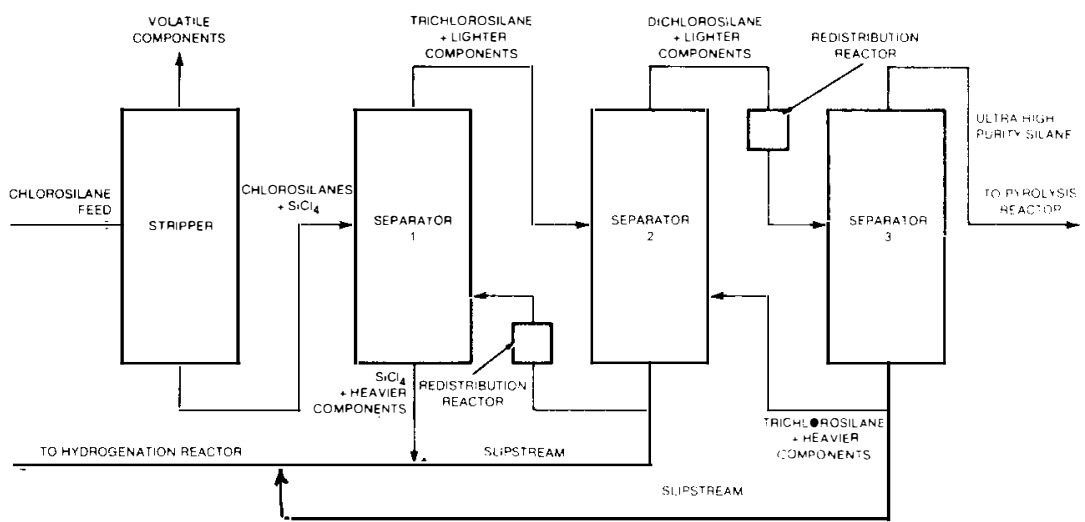

The Redistribution Reaction Section of the silane process progressively separates the heavier parts of the chlor osilane feedstock until a light silane product is available for pyrolysis. The color lines indicate additions to the process that prevent impurity buildup. The
redistribution reactors catalytically adjust the composition of the feed for more favorable separations.

A modification has been proposed to reduce impurity trapping in the silane process for producing semiconductorgrade silicon. A small amount of liquid containing impurities is withdrawn from the processing stages in which trapping Occurs and is passed to an earlier processing stage in which such impurities essing slage in which such impurities end to eactions.

The silane process is one of the most promising methods for producing silicon for low.cost solar cells by converting in expensive metallurgical-grade silicon to semiconductor-grade silicon In the silane process, the metallurgical-grade materia is first hydrogenated to produce mater is frs hydrogenated toproduce a feedstreamcomposed primarily of trichlorosilane and slicon tetrachioride but also containing other chlorosilane The feedstock is passed through a se ries of separator columns that produce ultra-high-purity silane $\left(\mathrm{SiH}_{4}\right)$. A pyro ysis reactor breaks down the silane into hydrogen, which is recycled to the hydrogenator, and semiconductorgrade silicon.

398
A problem with the silane process has been that certain impurities of intermed. ate volatility can become trapped in the separator loops. Eventually the impurities build up to the point where they over load the separator columns and con taminate the silane product.

In the modified process (see figure) a small stream of liquid is withdrawn from the last two separator columns and returned with recycled silicon tetrachlo. ride to the hydrogenator. There. some impurities are converted to insoluble metal complexes that settle and are removed with the heavy-waste stream Other impurities continue to the stripper column, where they pass off with other volatile components. (The stripper coland methane stream tron cream trom the hydrogenalor - al components having volatility equal to or greater than that of hydrogen sulfide

The effluent from the stripper - pri. marily trichlorosilane and silicon tetra. chloride essentially free of high-volatility contaminants - enters separator col. umn 1. There, trichlorosilane and lighter components are extracted and sent as the feed to separator column 2. Siiicon tetrachloride and heavier components are removed and relurned to the hydro genator

In separator 2. dichlorosilane and lighter components are extracted and ighter compc sent to separator column 3. Heavie chlorosilanes are returned to separato 1. except that in the new process a sma slipstream is diverted to the recycling silicon tetrachioride. The slipstream orevents impurities with volatility greater than that of trichoiorosilane but less than that of dichlorosilane trom becoming trapped and accumulating in the loop retween separators 1 and 2 . Such im between sepaccurs 1 and 2 such im. purities include boron trichlorive. phosphorus chioride and arsenic chloride.

In separator 3. Silane is extracted as the product. Diborane and other impurities are returned to separator 2 . and a slipstream is added to the silicon tetra chloride return. The silpstream preverits such impurities as boron hydride phos. phorus hydride, and arsenic hydride? 
from. Eulding up in ine 1000 betweer seoarato $c$ and 3

aris a.e sifficent

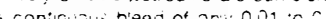
sercent of the soium no.
Streary is enough 10 riantain any of the a'ar :DoDs a' less This wer miltio

This work was are ty Latiy M Coleman of Linon Caroide Coro for
NASA's Jet Propulsion Laboratory.

For further information, Clircle 24 on

NPO $; 5217$ 
APPENDIX I

NASA TECH BRIEF:

REMOVING IMPURTTIES FROM SILANE

\section{Removing Chlorides From Metallurgical-Grade Silicon}

Process for making 'ow-cost silicon for solar cells is further improved.

-...............

NASA's Jet Propulsion Laboratory. Pasadena. California

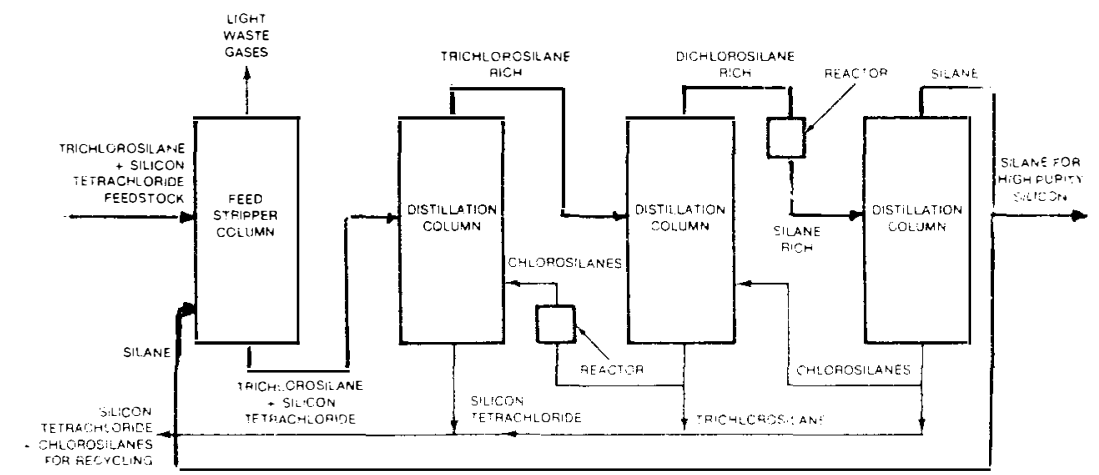
column with light wastes The mpurities - chlorides of arseric phus heavys and boton - would otherw se be camed to subseguent

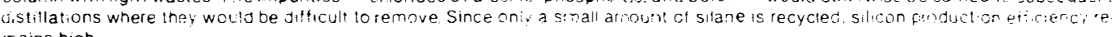
mains high

Upgrading metallirgica! grade slitcon io high.purity semiconductor.grade sili con for low-cosi solar cel!s requires a critical step ir: which chlorcsianies are separated from a sticon tetracricride carr er for further processing. When the chlorosilanes are separated. such im. purities as arsenic chloride. ohosphorus whorice and boron chloride teno to siay with them The retentwon of these mp with in ine teedsiock mposes a heaver mourty load on downstream processmounty load on downsteam process. ing eouipment and maxes il more dit. ficult to maintam high purity in the sitcon produc:

- Towever, a smali amount of stiane aoced is the chicroslarie and silicon te rachior:de ritxture elirrinates the imisi-

thes A smail portion of the suane pro Cuced in a rater reaction is simpiy diverted to the fieed stripper colimn which the cricrosuane ard sticon etra chioride are separated isee "igles The

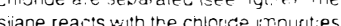
chane reacts with the chiorice limpurt:es hydnde hydr:des, such as arsemic . Fnoschoris hydride and boron readty removed along comprum:s are wasies in the columin

The sitare enters at the bourom ot teed strpper column sinct orate subsance " rises ine enire (II ins has a engin o! the coumn lit thus has alonger were injected a' a higher ievel r, the co umin Excess siane passes ont at the top watr the cine: con: Gases

of couse ire induity concerta toons in the teedstock are 3 iready ow Lsually less'rian 1 pom 10 ano: 10 com. Toensure compiete reaction the siame

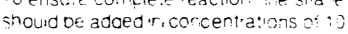
to $100 \mathrm{ppm}$ (moles of st!ane der :n:on rives - feedstockl This concentration repesents an msignificant ins ct con duct sllane to conversion ac sem conductor-grade sl:lcon

This work was cone ay iwitam Brenernar and Lary M Caerar " Unior Caroue Corp to: NASA's Jot Propulsion Laboratory. For furiner torriation Circte 25 on the iso Fie guest Carcs

NPO $1:-18$

u.s. Patent 4,340,574

July 20, 1982

NASA Tect Briefs. Spring/Summer 1982 


\section{APPENDIX J \\ NASA TECH BRIEF: \\ REMOVING IMPUR ITIES WITH THE CONTINUOUS-FLOW PROCESS}

\section{Low.Waste Purification of Silicon}

A continuous-flow process converts metallurgical-grade silicon to semiconductor-grade silicon.

NASA's Jet Propulsion Laboratory, Pasadena, California

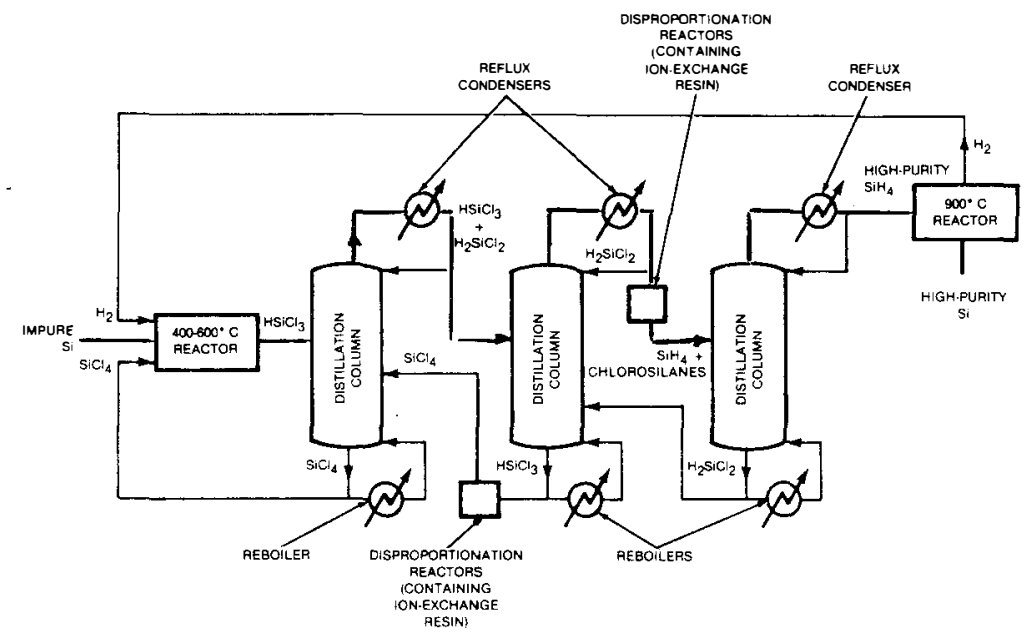

This Puriflcation Process starts with impure (metallurgical-grade) silicon and produces high-purity silicon suitable for semiconductor applications. The input silicon is reacted with hydrogen and silicon tetrachloride to produce chlorosilanes; by a combination of distilla. tion and disproportionation in resins, the silicon is converted to silane that is pyrolyzed to pure silicon. $\mathrm{The}_{2}$ and $\mathrm{SiCl}_{4}$ are recycled in the continuous.flow process

The uitra-high-purity silicon required for solar cells. transistors, and in tegrated circuits can be produced from metallurgical-grade silicon by the forma tion and pyrolysis of silane gas $\left(\mathrm{SiH}_{4}\right)$ in a continuous-flow process that max imizes product purity with a minimum amount of equipment. The integrated process recycles unreacted and byprod uct materials, thus minimizing materia Iosses and simplifying wastedisposal losses and simpling wastedsposal. also ensures theeflectiveren

The metallurgical-grade silicon is reacted with $\mathrm{H}_{2}$ and $\mathrm{SiCl}_{4}$ in the system shown in the figure to produce chlorosıanes $\left(\mathrm{H}_{x} \mathrm{SiCl}_{4-x}\right)$ By a combination of distillation and redistribution, the lighter (hydrogen-rich) chlorosilanes progress through the system, and the heavier (chlorine-rich) ones are fed back to distilation columns and to disproportionation or hydrochiorination reaciors. The ove all process consumes the silicon and produces high-purity $\mathrm{SHH}_{4}$ that is pyrolyzed to high-purity submicron par. ticles of siticon. The Hz produced in the pyrolysis is fed back to the hydrochloripyrolysis is fed the

Metalic impurities are fluxed out of the system by periodic draining of small amounts of contaminated $\mathrm{SiCl}_{4}$. Boron is specially removed by the disproportion ation resins and controlled distillation
The principal merit of this system is the specific sequence in which the different steps are integrated. As the figure shows the first distillation column recycles $\mathrm{SiCl}_{4}$, the third column separates out ultra-high-purity $\mathrm{SiH}_{4}$, and the intermediate second column separates fractions that pass to resin disproportionation-reaction zones.

This work was done by William $C$ Breneman and Larry M Coleman of Union Carbide Corp for NASA's Jot Union Carbide Corp. for Nasa's jot Propulsion Laboratory. For further information. Circle 23 on the TSP Re quest Card

NPO. 15033 


\title{
APPENDIX $\mathrm{R}$
}

\section{ROMATSU SILANE DATA SHEET}

\author{
$\mathrm{SiH}_{4}$ Gas \\ (Monosilane)*
}

\section{Outstanding Characteristics}

\author{
Boron content: less than $0.02 \mathrm{ppb}$ \\ Resistivity of deposit: more than $500 \mathrm{ohm}-\mathrm{cm}$.
}

Komatsu Monosilane Gas can not be matched by any other gases of this kind in its high purity, high resistivity, uniformity and reliability. Komatsu's proprietary process and the biggest production in the world naturally give such properties to the monosilane gas.

Resistivity of deposited film will be 2,000 ohm-cm minimum, as all gas-producing systems are well controlled. Due to its high purity and no halides contained, Komatsu monosilane gas is ideal for epitaxial growth, thin film deposition and formation of perfect layer of silicon oxide and silicon nitride.

Komatsu monosilane gas is usually supplied in undiluted condition in an appropriate iron cylinder. The cylinder standard capacity is approximately 10 or 40 litre water content. The gas pressure is approx. $72 \mathrm{~kg} / \mathrm{cm}^{2}-1,000$ pounds per square inch. In this case, the gas weight is approximately $1 \mathrm{~kg}$ in a 10 litre cylinder. Diluted gas with high purity diluents such as hydrogen, nitrogen or argon will be available upon request.

\section{General Properties}

Monosilane is a colorless and ordorless gas at room temperature, and is spontaneously flammable in air and other oxidizing gases, and reacts violently with free halogen or heavy metal hydrides. It will decompose into silicon and hydrogen by heating higher than $300^{\circ} \mathrm{C}$, and by an electric discharge.

Physical constants are as follows.

$\begin{array}{ll}\text { Molecular weight: } & 32.12 \\ \text { Boiling point: } & -112^{\circ} \mathrm{C}\left(-169.6^{\circ} \mathrm{F}\right) \\ \text { Freezing point: } & -185^{\circ} \mathrm{C}\left(-3011^{\circ} \mathrm{F}\right) \\ \text { Critical temperature: } & -4^{\circ} \mathrm{C}\left(24.8^{\circ} \mathrm{F}\right) \\ \text { Critical pressure: } & 48 \mathrm{~atm} \\ \text { Specific volume at } 70^{\circ} \mathrm{F}, 1 \mathrm{~atm} .12 .049 \mathrm{cf} / 1 \mathrm{~b} . \\ \text { Heat of formation: } & 7.2 \mathrm{Kcal} / \mathrm{mol} \\ \text { Density--gas at } 20^{\circ} \mathrm{C}: & 1.44 \mathrm{~g} / \mathrm{L}\end{array}$

*Adapted from data sheet No. 105 issued by Komatsu Electronic Metals Co., Ltd., Tokyo, Japan. 
APPENDIX L

SILANE DATA SHEETS

\section{Airco Industrial Gases}

\section{Silane $\mathrm{SiH}_{4}$}

\section{Product Description}

Silane is available from Airco Specialty Gases in the pure form or as a gas mixture. Three grades are available:

\section{Electronic Grade}

V.L.S.I. Grade

C.C.D. or Nitride Grade - an ultra high purity product developed specifically to meet the demands of the charge coupled device and high purity nitration.

Specifications

Purity - Electronic Grade

Oxygen

Chlorosilanes

Carbon Monoxide

Carbon Dioxide

Moisture

Hydrogen

Typical Resistivity

\section{Maximum} Impurities

$10 \mathrm{ppm}$
$1000 \mathrm{ppm}$

$20 \mathrm{ppm}$

$3 \mathrm{ppm}$

$5000 \mathrm{ppm}$

$50 \mathrm{ppm}$

$>100 \mathrm{ohm} / \mathrm{cm}$

Typical
Analysis

Analysis
$<\mathrm{ppm}$
$<100 \mathrm{ppm}$

Purity - V.L.S.I. Grade*

Oxygen

Chiorosilanes

Carbon Monoxide

Carbon Dioxide

Moisture

Hydrogen

Methane

Typical Resistivity

$<\quad 5 \mathrm{ppm}$
$<\quad 1 \mathrm{ppm}$

$<1000 \mathrm{ppm}$

$<30 \mathrm{ppm}$

$>100$ pricm

Purity - C.C.D. or Nitride Grade*

Oxygen

Nitrogen

Chiorosilanes

Carbon Monoxide

Carbon Dioxide

Moisture

Argon

Hydrogen

Methane

Maximum

Impurities

$10 \mathrm{ppm}$

00 ppm

$5 \mathrm{ppm}$
$3 \mathrm{ppm}$

$3 \mathrm{ppm}$
$000 \mathrm{ppm}$

$30 \mathrm{ppm}$

$100 \mathrm{ohm} / \mathrm{cm}$

Typical

Analysis

$1 \mathrm{ppm}$
$<100 \mathrm{ppm}$

Typical Resistivity

$<\quad 5 \mathrm{ppm}$ < $\begin{array}{r}1 \mathrm{ppm} \\ <500 \mathrm{ppm}\end{array}$ $<\quad 5 \mathrm{ppm}$ 


\section{Airco Industrial Gases (Concluded)}

\section{General Information}

C.C.D. or Nitride grade silane has been developed to meet the more stringent demands for carrier lifetime and mobility of charge coupled semiconductor devices. It is capable of growing epitaxial silicon with a resistivity in excess of $2500 \mathrm{ohm} / \mathrm{cm}$.

Cylinders to be used with silane or silane mixtures are treated individually from the start They are specially prepared by the manufacturer before shipment to Airco, where they undergo an extensive cleaning and passivation sequence. Once this has been completed the cylinders are filled and then remain only in silane service.

\section{Special Note}

In order to meet the high purity requirements of this material, specially treated aluminum cylinders (Spectra Seal®) must be used. When provided in Airco's Spectra Seal cylinder, gas specifications listed will not change with time or temperature through at least $90 \%$ of product usage Shelf life is guaranteed to be at least one year.

\section{Product Handling}

To help us maintain these levels of purity, please read our data sheet - "Procedures for the storage and handling of electronic gases."

Cylinder Sizes-

Electronic grade silane is available in steel cylinders containing $15,000 \mathrm{gm}, 10,000 \mathrm{gm}$ or $500 \mathrm{gm}$. Mixtures are available in \#200 and \#80 size cylinders.

V.L.S.I. grade is available in a size \#150A Spectra Seal aluminum cylinder containing 5,000 grams of material. V.L.S.I. mixtures are available in \#150A and \#30A size Spectra Seal aluminum cylinders

C.C.D. or Nitride grade is only available in Spectra Seal aluminum cylinders containing $5,000 \mathrm{gm}, 2,500 \mathrm{gm}, 1,000 \mathrm{gm}$ or $500 \mathrm{gm}$. Mixtures are available in \#150A and \#30A size Spectra Seal aluminum cylinders.

Cylinder Valve Outlets-

For all silane and silane mixture cylinders: CGA \#350.

Handling Equipment-

Regulator Model -

Stainless Steel Model \#52-75 (350)

Flowmeter Model -

Stainless Steel Model S75*

- A number of standard ranges are available 
II. Air Products and Chemicals, Inc.

\section{Gases \&} Chemicals

\section{Rhenium Hexafluoride (ReF6)}

A toxic, light-yellow, nonflammable liquid with a detectable odor. Reacts with water to form hydrofivoric aclid.

Toxicity-Toxic. Severely irritating and corrosive to tissues, producing burns typical of hydrotluoric

Molecular Weight-300 19

Cylinder Pressure at $70^{\circ} \mathrm{F}\left(21.1^{\circ} \mathrm{C}\right)-0$ psig $(0 \mathrm{kPa})$

Cyllinder Valve Outlet-1/4" compression fitting

Compatible Materlas - Monel and nicket are the Liquid Density at $77^{\circ} \mathrm{F}\left(25^{\circ} \mathrm{C}\right)-384 \mathrm{lb} / \mathrm{ft}^{\prime}\left(6,15 \mathrm{t} \mathrm{kg} / \mathrm{m}^{3}\right.$

Cylinder Color-Stainless steet

DOT Hazard Class-Corrosive Material

DOT Label-Corrosive

and stainiess steel can be used at room tempera-

ture. Teflon is resistant and recommended for

gaskets.

G.P. Grade

$97.0 \%$

\begin{tabular}{|c|c|c|c|c|}
\hline $\begin{array}{l}\text { CrLIMOEn } \\
\text { SRE }\end{array}$ & $\begin{array}{l}\text { COAmmooity } \\
\text { COOE }\end{array}$ & $\begin{array}{l}\text { CYLINOER DIMENSIONS } \\
\text { in }\end{array}$ & 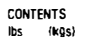 & $\begin{array}{l}\text { GAOSS WEIGHT } \\
\text { los (kgs) }\end{array}$ \\
\hline L.8. & $J 06-A-865000$ & $2 \times 15(5 \times 37)$ & (0.91) & $5.0 \quad$ (2) \\
\hline
\end{tabular}

ALCOMALHORD RQUIPMEWT

DEMWODIT
CODE
RANGE PSig (KPa)

Manual Control Valve

Monel without gauge

118

F.O.B. Hometown. PA

\section{Silane $\left(\mathrm{SiH}_{4}\right)$}

A colorless, extremely reactive. compressed gas.

Toxicity-Toxic

TWA-5 ppm

Fire Potential-Pyrophoric, low concentrations may

accumulate without pyrophoric ignitio

Compatible Materials - Noncorrosive to most

melas. Iron. brass. sleel. stainless sleet or

Molecular Weight-32 12

Ignites spontaneousiy in air.

\section{Witride Grade}

ORDERIMG IMFORMATIOH

\begin{tabular}{|c|c|c|}
\hline $\begin{array}{l}\text { CruMOER } \\
\text { SIZE }\end{array}$ & $\begin{array}{l}\text { Commoorry } \\
\text { COOE }\end{array}$ & $\begin{array}{l}\text { CYLINOER DIMENSIO } \\
\text { in }\end{array}$ \\
\hline 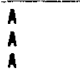 & $\begin{array}{l}A 01-0-465275000 \\
A 01-8-465273000 \\
A 01-X-465271000\end{array}$ & $\begin{array}{l}9 \times 55(23 \times 14 \\
9 \times 55(23 \times 14 \\
9 \times 55(23 \times 14\end{array}$ \\
\hline
\end{tabular}

Cytinder Pressure at $70^{\circ} \mathrm{F}\left(21.1^{\circ} \mathrm{C}\right)$
A $10.000 \mathrm{~g}$
$\quad 1.250 \mathrm{Ds} i \mathrm{~g}(8.619 \mathrm{kPa})$

A $-\frac{10,000}{5,000}$

30009

$3.0009-\frac{530 \mathrm{psig}(3.654 \mathrm{kPa}}{192 \mathrm{osig}(1.324 \mathrm{kPa}}$

0.1

192 osig $(1.324 \mathrm{kPa}$

Specific Volume at $70^{\circ} \mathrm{F}$ and 1 atm

[21.1 $\mathrm{C}$ and $101.3 \mathrm{kPa}$ (abs)]

Cylinder Color-Red

Cout Outle-CGA 350

DOT Hazard Class-Flammabie Gas

DOT Label-Flammable Gas

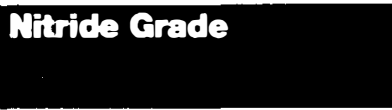

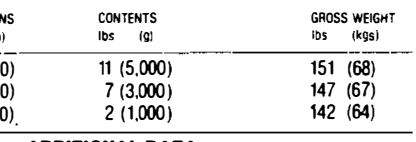

RECOMMEMDID EOUIPUITW

$\begin{array}{lll}\text { COMMODIT } & \text { DELIVEAY PAESSUPE } \\ \text { CODE } & \text { RANGE PSIg (kPa) } & \\ \end{array}$

Two-seseo Reoulatore

Two-stogo hoguiasors

E12-3-C442D $0-100(0-690)$

ADDITIONAL DATA

Other cylinder sizes are available on request

SPECIALTY GAS DEPT.

AIR PRODUCTS AND CHEMICALS, INC.

BOX 538

ALLENTOWN, PA 18105-0538

NOTE-Refer to enclosed Price List for current pricing information 
II. Air Products and Chemicals, Inc. (Continued)

Silane (Continued)

\section{Semiconductor Grade \\ $\supset 100$ ohm-cm}

\begin{tabular}{|c|c|c|c|c|}
\hline $\begin{array}{l}\text { erumoen } \\
\text { stax }\end{array}$ & $\begin{array}{l}\text { commontry } \\
\text { cosef }\end{array}$ & $\begin{array}{l}\text { CYLINDER OIMENSIONS } \\
10 \\
\text { (cm) }\end{array}$ & $\begin{array}{l}\text { CONTENTS } \\
\text { IDS (9) }\end{array}$ & $\begin{array}{l}\text { GROSS WEIGHT } \\
\text { los (kgS! }\end{array}$ \\
\hline$\hat{\hat{A}}$ & 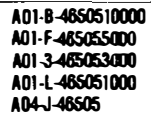 & $\begin{array}{l}9 \times 55(23 \times 140) \\
9 \times 55(23 \times 140) \\
9 \times 55(23 \times 140) \\
9 \times 55(23 \times 140) \\
6 \times 19(15 \times 48)\end{array}$ & $\begin{aligned} & 22(10,000) \\
& 11(5,000) \\
& 7(3,000) \\
& 2(1,000) \\
& 0.2(100)\end{aligned}$ & $\begin{aligned} 162 & (73) \\
151 & (68) \\
147 & (67) \\
142 & (64) \\
12 & (5)\end{aligned}$ \\
\hline \multicolumn{5}{|c|}{$\begin{array}{l}\text { ADDITIOMAL DATA } \\
\text { For silane mixtures and other gases used } \\
\text { by the semiconductor industry turn to } \\
\text { page } 86 .\end{array}$} \\
\hline
\end{tabular}

AECOMMENDED ROUIPMENT

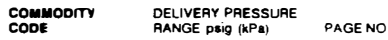

rearsteng Rogulor

T12-6-C45A $0-25(0-172)$

(12- $-C 445 B$ 0-25 (0-172)

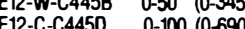

$\begin{array}{ll}\text { E12-C-C445D } & 0-100(0-690) \\ \text { E12-U-C445F } & 0-250(0-1,724)\end{array}$

or silane mixtures and other gases used

page 86

\section{Silicon Tetrachloride $\left(\mathrm{SiCl}_{4}\right)$}

A loxic, colortess, nonllammable liquid with a hydrogen chloride

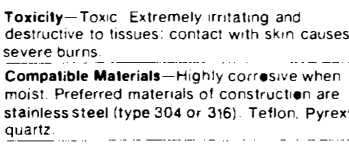

Toxicity-Toxic Extremely irritating and destructive to tissues: contact with skin causes severe burns

Compalible Malerials - Highiy corcasive when

moist. Preferred materiais of construction are

quartz.

Molecular Weight -1699

Cylinder Pressure at $70^{\circ} \mathrm{F}\left(21.1^{\circ} \mathrm{C}\right)-0 \mathrm{psig}(0 \mathrm{KP}$ a

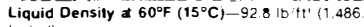

$\underline{\left.\mathrm{kg} / \mathrm{m}^{\mathrm{s}}\right)}$

Cylinder Color-Silver

Cylinder Valve Oullet -3 8. compression titing

\section{Semiconductor Grade}

ORDERING IMFORIAATION

\begin{tabular}{|c|c|c|c|c|}
\hline CrIMOEN & commoortr & CYLINOEA DIMENSIONS & CONTENTS & GAOSS WEIGH \\
\hline $5 \mathrm{gal}$ & A51-K-46805 & $12 \times 19(30 \times 48)$ & $55(250)$ & (36) \\
\hline
\end{tabular}

ADditional Data Dot Label-.-Corrosive

For other gases used by the semiconducto

AECOMMINADED EOUIPWEMT

COMMOOIT DELIVEAY PAESSURE
CODE

\section{Mone Required}

Material is liquid unde

normal conditions.

industry turn to page 86 .

F.O.B. Hometown. PA

Pyrex : is a registered trademark of Corning Glass Works

\section{AdirProducts}


II. Air Products and Chemicals, Inc. (Continued)

AdirProducts

\section{Specialty Gas Data Sheet}

\section{SILANE}

\section{SILANE/SILICON TETRAHYDRIDE $\left(\mathrm{SiH}_{4}\right)$ SPECIFICATIONS

\author{
Resistivity \\ $>100 \mathrm{ohm}-\mathrm{cm}$
} \\ A sample of each batch of epi gradesilane is evaluated on our own reactor. Silane is deposited on silicon substrates and then the resistivity of the undoped layers is measured.}

\section{PHYSICAL PROPERTIES}

Molecular weight

Boiling point at $1 \mathrm{~atm}$

Color

Critical density

Critical pressure

Critical temperature

Density, Gas at 1 atm $32^{\circ} \mathrm{F}\left(0^{\circ} \mathrm{C}\right)$

Flammable limits in air

Melting point at 1 atm

Specific gravity at $-301^{\circ} \mathrm{F}\left(-185^{\circ} \mathrm{C}\right)$

(Air = 1)

Specific volume at $1 \mathrm{~atm} 70^{\circ} \mathrm{F}$ $\left(21.1^{\circ} \mathrm{C}\right)$

Vapor pressure at $-220.9^{\circ} \mathrm{F}$

$\left(-140.5^{\circ} \mathrm{C}\right)$

Viscosity at 1 atm $59^{\circ} \mathrm{F}\left(15^{\circ} \mathrm{C}\right)$

TYPICAL APPLICATION

Silane is used as a source of high purity silicon for epitaxia and thin film deposits, and

for low temperature vapor

deposition of silicon oxide and silicon nitride.
32.12

$-170^{\circ} \mathrm{F}\left(-112^{\circ} \mathrm{C}\right)$

Colorless

$45.6 \mathrm{lb} / \mathrm{ft}^{3}\left(730.4 \mathrm{~kg} / \mathrm{m}^{3}\right)$

702.5 psia

$25.7 \mathrm{~F}\left(-3.5^{\circ} \mathrm{C}\right)$

$0.0826 \mathrm{lb} / \mathrm{ft}^{3}\left(1.32 \mathrm{~kg} / \mathrm{m}^{3}\right)$

Pyrophoric, spontaneously

flammable

$-301^{\circ} \mathrm{F}\left(-185^{\circ} \mathrm{C}\right)$

0.68

$12.1 \mathrm{ft}^{3} / \mathrm{lb}\left(0.755 \mathrm{~m}^{3} / \mathrm{kg}\right)$

1.9 psia

112.4 micropoise

SAFETY CONSIDERATIONS

Flammability

CAUTION

EXTREMELY FLAMMABLE.

DO NOT EXPOSE TO

THE ATMOSPHERE

The major hazards of silane are associated with its pyrophoric properties. Silane is spontaneously flammable upon contact with air or with oxidizing gases.

it reacts violently with most free

halogens or heavy metal hydrides.

When heated to $572^{\circ} \mathrm{F}\left(300^{\circ} \mathrm{C}\right)$

silane begins to decompose into silicon and flammable hydrogen $\left(\mathrm{SiH}_{4} \rightarrow \mathrm{Si}+2 \mathrm{H}_{2}\right)$. It is also decom posed by an electric discharge. Keep the product away from heat sparks, and open flame.

Toxicity

The American Conference of Governmental Industrial Hygienists has recommended a threshold limit of $0.5 \mathrm{ppm}$ for silane.

The toxicological properties have not been fully investigated. If inhaled, it may be irritating to the respiratory tract and may cause headache and nausea. Use only with adequate ventilation. If silane is inhaled remove the victim to fresh air and keep him warm and quiet. If respiration has stopped, start mouth-to-mouth artificial respiration at once. Seek medical assistance promptly.

\section{GENERAL HANDLING} INFORMATION

Silane should be stored and handled in well-ventilated areas at positive pressures. Isolate from halogens, oxygen and combustible, organic, or oxidizing materials. Avoid contact with air at all times.

Silane is generally noncorrosive toward most construction materials. Use diaphragm pack- 
II. Air Products and Chemicals, Inc. (Concluded)

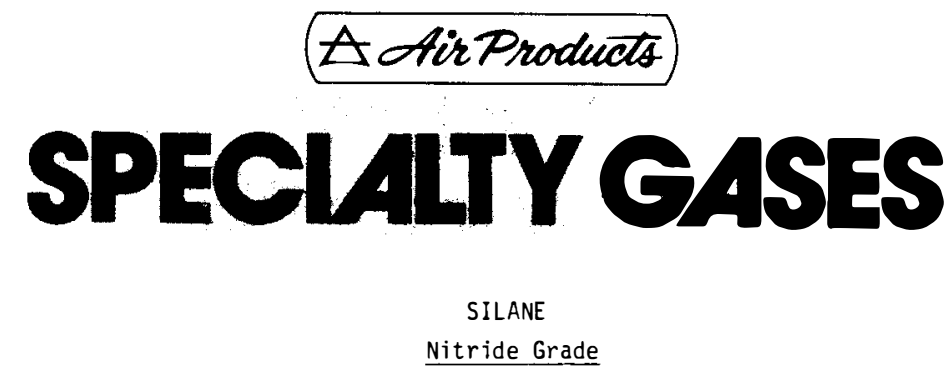

APCI Specification

Hydrogen

Oxygen

Argon - Rare

Ni trogen

Chlorides

THC

$\mathrm{CO} / \mathrm{CO}_{2}$

Water

Resistivity
$<500 \mathrm{ppm}$

$<10 \mathrm{ppm}$

$<40 \mathrm{ppm}$

$<40 \mathrm{ppm}$

$<10 \mathrm{ppm}$

$<10 \mathrm{ppm}$

$<5 \mathrm{ppm}$

$\leq \quad 1 \mathrm{ppm}$

$>100 \mathrm{ohm}-\mathrm{cm}$
"SEMI" Specification

$\leq 500 \mathrm{ppm}$

$\leq 10 \mathrm{ppm}$

$\leq 40 \mathrm{ppm}$

Not Specified

$\leq 10 \mathrm{ppm}$

$\leq 10 \mathrm{ppm}$

$\leq 10 \mathrm{ppm}$

$\leq 3 \mathrm{ppm}$

$>50$ onm-crll

Gaseous Chemicals - Fluorine Compounds • Chemical intermediates • Rare Gases • Custom Blen 


\section{Ideal Gas Products, Inc.}

\section{Pure Electronic Gases}

Thousand Ohm Plus Silane (T.O.P.S• Grade) is an exclusive new product, manufactured by Certified Gas and Controls, Inc.; sold and distributed by Idea Gas Products, Inc. This product was made possible by the successful development of a totally new concept in silane purification.

In manufacturing silicon devices in clean systems, T.O.P.S:Sllane will increase yields, improve carrie mobility, lifetime, and remove thermal effects due to impurity carrier thermal activation. Remarkable gains in yield (up to $400 \%$ ) have been obtained in production usage where the only parameter changed was from the use of "relatively impure" standard epi or electronic grade silane to T.O.P.S:Silane.

Maintaining the extraordinarily high quality of T.O.P.S: Silane is our primary concern, and because of this, each cylinder is analyzed. Spread ing conductance measurements are made on every lot of T.O.P.S: Silane to verify its exceptional resis tivity. A bulk sample of silicon with a resistivity measured at $1750 \mathrm{ohm} \mathrm{cm}$ by a 4-point measure ment is used for high end calibration. The raw resis tance measured with this calibration sample is near to 1 megohm, with conductance $G$ equal to 0.9 to 1.0 micromhos with the probe head used in our measurements. Only epi deposited from T.O.P.S Silane in a clean system and which exhibits a raw conductance less than $\mathbf{1 . 2}$ micromhos is considered acceptable.

In addition, dCldV plotting is made to measure carrier concentration. With observed carrier concentrations below $3 \times 10^{12}$ per cubic centimeter as measured by dCldV plotting, and with $5 \times 10^{22}$ silicon atoms per cubic centimeter, the net NA-ND of less than 60 carrier contributing atoms per billion silicon atoms indicates the order of total impurities. Since othersilanes are more strongly $N$ type, this is an indication that the purification of TOP.P. ${ }^{*}$ is

IDEAL GAS PRODUCTS. INC

PO. Box 709

Edison. New Jersey 08817 effective in reducing the level of phosphine (which is usually present at the low part per billion level) to the low part per trillion range. Since heavier elements would be more effectively removed than phosphorus by the purification processes employed, it is obvious that other heavy elements are removed to an even greater degree than phosphorous. Detection by any method other than electrical measurements on a single crystal structure deposited from this silane is impractical. A long list of elements at non-detectable levels would seem to be meaningless when the purity indicated by the carrier concentration is considered.

Concentration of other typical gaseous impurities is also closely monitored on each individual cylin. der as shown below. Particular attention is given to cylinder preparation for T.O.P.S. Silane and for mixtures of T.O.P.S: with various carrier gases such as helium, hydrogen, nitrogen or argon, all of which are UHP grade gases.

\section{Purity Specifications:}

Resistivity: $\quad 1,000$ ohms/cm minimum undoped epitaxial silicon deposited in a clean system.

Chlorosilane: Non-detectable by sparging 10 liters of silane through $125 \mathrm{ml}$ of deionized water (conductance $<0.5$ micromhos) without measurable increase in conductance. (This test method will also detect any impurity ionizable at infinite dilution.)

\section{Hydrogen: $100 \mathrm{ppm}$ maximum}

Nitrogen: $10 \mathrm{ppm}$ maximum

Total Hydrocarbons as Methane: 2 ppm maximum Moisture: $2 \mathrm{ppm}$ maximum 
III. Ideal Gas Products, Inc. (Concluded)

\section{Ideal Gas Products, Inc.}

\section{Pure Electronic Gases}

\begin{tabular}{|c|c|c|c|c|c|c|c|}
\hline Purity & $\begin{array}{l}\text { Molecular } \\
\text { Weight }\end{array}$ & $\begin{array}{l}\text { Specific } \\
\text { Volume }\end{array}$ & $\begin{array}{l}\text { Cylinder } \\
\text { Valve } \\
\text { Outlet }\end{array}$ & $\begin{array}{l}\text { Cylinder } \\
\text { Size }\end{array}$ & Contents & Price & $\begin{array}{l}\text { Recommended } \\
\text { Regulators }\end{array}$ \\
\hline $\begin{array}{l}\text { AMMONIA. } \\
\text { Electr@nic. } 99.995 \div 0 \\
\mathrm{H}_{2} \mathrm{O}<10 \mathrm{ppm}\end{array}$ & 17.031 & $\begin{array}{c}22.5 \\
\mathrm{cu} .1 \mathrm{t} . \mathrm{lb} .\end{array}$ & CGA 660 & $\begin{array}{l}57 \\
16\end{array}$ & $\begin{array}{l}55 \mathrm{lus} . \\
16 \mathrm{ibs} .\end{array}$ & $\begin{array}{r}\$ 300.00 \\
75.00\end{array}$ & 1500 Series \\
\hline $\begin{array}{l}\text { ARSINE, } \\
\text { Electronic. } 99.998 \%\end{array}$ & 77.946 & $\begin{array}{l}5.0 \\
\text { cu. ft. } / \mathrm{b} \text {. }\end{array}$ & CGA 350 & $\begin{array}{l}7 \\
7\end{array}$ & $\begin{array}{c}5 \mathrm{lbs} \\
1 \mathrm{lb}\end{array}$ & $\begin{array}{r}\$ 750.00 \\
175.00\end{array}$ & 1500 Series \\
\hline $\begin{array}{l}\text { CHLORINE. } \\
\text { Electronic. } 99.98 \%\end{array}$ & 70.906 & $\begin{array}{l}5.4 \\
\text { culftilb. }\end{array}$ & CGA 660 & $\begin{array}{r}16 \\
7 \\
3\end{array}$ & $\begin{array}{l}40 \mathrm{lbs} \\
15 \mathrm{lbs} \\
6 \mathrm{lts}\end{array}$ & $\begin{array}{r}\$ 300.00 \\
17000 \\
100.00\end{array}$ & 1500 Series \\
\hline $\begin{array}{l}\text { DICHLOROSILANE } \\
\text { Resistivity Capability: } \\
\geq 50 \text { ohms:cm. N type }\end{array}$ & 100.99 & $\begin{array}{c}3.83 \\
\mathrm{cu} . \mathrm{ft} / \mathrm{tb}\end{array}$ & CGA 330 & 44 & $50 \mathrm{lbs}$ & $\$ 1500.00$ & 1500 Series \\
\hline $\begin{array}{l}\text { GERMANE, } \\
999 \%\end{array}$ & 76.62 & $\begin{array}{c}5.1 \\
\text { cult }\end{array}$ & CGA 350 & 7 & $100 \mathrm{~g}$ & $\begin{array}{c}\text { On } \\
\text { Reciues: }\end{array}$ & $\begin{array}{l}1500 \text { Series or } \\
900 \text { Series }\end{array}$ \\
\hline $\begin{array}{l}\text { HYDROGEN } \\
\text { CHLORIDE, } \\
\text { Electronic. } 99.995 \%\end{array}$ & 36.461 & $\begin{array}{c}10.9 \\
\text { cu. ft./lb. }\end{array}$ & CGA 330 & $\begin{array}{r}44 \\
7\end{array}$ & $\begin{array}{l}55 \mathrm{lbs} \\
8 \mathrm{lbs}\end{array}$ & $\begin{array}{r}\$ 255.00 \\
6 \mathbf{0} .00\end{array}$ & $\begin{array}{l}1500 \text { Series or } \\
1900 \text { Series }\end{array}$ \\
\hline $\begin{array}{l}\text { HYDROGEN } \\
\text { SELENIDE. } \\
\text { Electiønic. } 99.95\end{array}$ & 80976 & $\begin{array}{l}48 \\
\text { custilt }\end{array}$ & CGA 350 & $\because$ & $1 \mathrm{lb}$ & $\$ 450.00$ & $\begin{array}{l}1500 \text { Serkes or } \\
1900 \text { Series }\end{array}$ \\
\hline $\begin{array}{l}\text { HYDROGEN SULFIDE, } \\
\text { Electronic. } 99.99^{\circ}\end{array}$ & 34.08 & $\begin{array}{c}11.2 \\
\mathrm{cu} . \mathrm{ft} . \mathrm{Ib}\end{array}$ & CGA 330 & 16 & 20 ibs. & $\$ 275.00$ & 1500 Series \\
\hline $\begin{array}{l}\text { NITROUS OXIDE, } \\
\text { Electronic. 99.995: }\end{array}$ & 44.01 & $\begin{array}{l}8 ? \\
\text { cut itib. }\end{array}$ & CGA 326 & $\begin{array}{l}44 \\
16\end{array}$ & $\begin{array}{l}60 \mathrm{lbs} \\
20 \mathrm{lbs}\end{array}$ & $\begin{array}{r}\$ 660.00 \\
280.00\end{array}$ & $\begin{array}{l}1400 \text { Series or } \\
1600 \text { Series }\end{array}$ \\
\hline $\begin{array}{l}\text { PHOSPHINE, } \\
\text { Electronic. } 99.998^{\circ}\end{array}$ & 34.00 & $\begin{array}{c}11.4 \\
\mathrm{cu} .4 t . i l \mathrm{~b}\end{array}$ & CGA 350 & $\begin{array}{r}16 \\
3\end{array}$ & $\begin{array}{r}5 \mathrm{lbs} \\
1 \mathrm{lb}\end{array}$ & $\begin{array}{r}\$ 650.00 \\
175.00\end{array}$ & $\begin{array}{l}1500 \text { Series or } \\
1900 \text { Series }\end{array}$ \\
\hline $\begin{array}{l}\text { SILANE, T.O.P.S. " } \\
\text { Resistivity } \\
21.000 \text { ohmsicri } \\
\mathrm{CH}<2 \text { ppm } \\
\text { Uncomperisated }\end{array}$ & 32.12 & $\begin{array}{c}12.1 \\
\text { cut } 1 \mathrm{t} .110\end{array}$ & CGA350 & $\begin{array}{c}44 \\
44 \\
44 \\
i \\
\text { pecitican }\end{array}$ & $\begin{array}{r}10.000 \mathrm{~g} \\
5.000 \mathrm{~g} \\
1.000 \mathrm{~g} \\
100 \mathrm{~g}\end{array}$ & $\begin{array}{r}\$ 6.08000 \\
3.10000 \\
590.00 \\
15000\end{array}$ & $\begin{array}{l}1500 \text { Serres or } \\
1900 \text { Serles }\end{array}$ \\
\hline $\begin{array}{l}\text { SILANE. Electronic } \\
\text { Resistivity } \geq 100 \text { ohms } / \mathrm{cm} \\
\text { Uncoinpensated }\end{array}$ & 32.12 & $\begin{array}{c}12.1 \\
\text { cuft it it. }\end{array}$ & CGA 350 & $\begin{array}{r}44 \\
44 \\
7\end{array}$ & $\begin{array}{l}5.000 \mathrm{~g} \\
1.000 \mathrm{~g} \\
100 \mathrm{~g}\end{array}$ & $\begin{array}{r}\$ 1700.00 \\
400.00 \\
85.00\end{array}$ & $\begin{array}{l}1500 \text { Serles or } \\
1900 \text { Stries }\end{array}$ \\
\hline
\end{tabular}

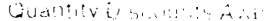




\section{Linde Division, Union Carbide Corporation}

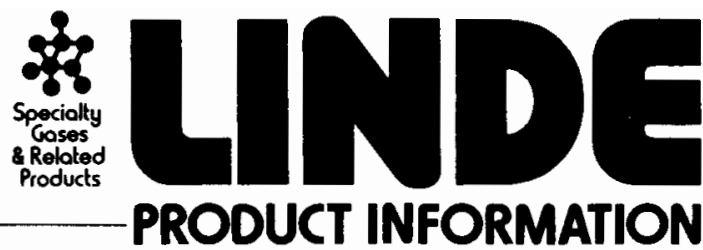

SILANE

$\mathrm{SiH}_{4}$

\section{FEATURES}

- Resistivity greater than 100 ohm $\times$ m

- Lowest epitaxial temperature

- No corrosive by-products

- Maximum conversion efficiency to silicon

- Useable with sapphire substrates

- Accurate gas feed

Union Carbide Silane is widely accepted for epitaxial deposition of single crystal films and for polycrystalline silicon. The silicon content of silane is greater than that of any of the chlorosilanes. Its principal high temperature reaction is one of simple pyrolysis.

$$
\mathrm{SiH}_{4} \longrightarrow \mathrm{Si}+2 \mathrm{H}_{2}
$$

There are no corrosive by-products from the pyrolysis and none of the reverse reactions common to the chlorosilanes are present.

Deposition temperatures, of Silane, as low as $800^{\circ} \mathrm{C}$ in helium with no loss of crystallinity are possible. Low growth temperatures obtainable with silane tend to minimize impurity diffusion effects which become appreciable above $1000^{\circ} \mathrm{C}$

Growth rates observed with silane are determined by the individual process and reactor geometry. Typically, rates between 0.2 microns per minute and 0.5 microns per minute are used for silicon epitaxy on a silicon substrate and up to 8.0 microns per minute are used for silicon epitaxy on sapphire substrates.

Silane usage is not limited to epitaxy. Low temperature chemical vapor deposition of silicon dioxide films by controlled oxidation of silane are finding increasing usage.

$$
\mathrm{SiH}_{4}+\mathrm{O}_{2} \longrightarrow \mathrm{SiO}_{2}+2 \mathrm{H}_{2}
$$

Some of the uses of silicon dioxide films are in integrated circuit manufacturing for device passivation, as dielectrics in multilevel metalized circuits and in MOS technology.
Chemical vapor deposition of silicon nitride films formed by the controlled reaction of silane and ammonia are also being increasingly used.

$$
3 \mathrm{SiH}_{4}+4 \mathrm{NH}_{3} \longrightarrow \mathrm{Si}_{3} \mathrm{~N}_{4}+12 \mathrm{H}_{2}
$$

Typical applications of silicon nitride films are insulation, passivation and sealing of devices and integrated circuits.

Silane is shipped as a gas in high pressure cylinders. It is also available in gas mixtures with hydrogen, helium, argon or nitrogen. Since it is supplied in gaseous form, it may be very precisely metered into reactors, eliminating the need for bubblers and their inherent inaccuracies.

Established conditions for chemical vapor deposition reac.

\begin{tabular}{|c|c|}
\hline & \\
\hline & colorle \\
\hline olecular Weight . . & 32.1 \\
\hline pecific Volume @ $70^{\circ} \mathrm{F}, 1 \mathrm{~atm}$ & $12.0 \mathrm{ft}^{3} / \mathrm{lb}$ \\
\hline oiling Point @ 1 atm ..... & $-169^{\circ} \mathrm{F}\left(-112^{\circ} \mathrm{C}\right)$ \\
\hline reez & $-301^{\circ} \mathrm{F}\left(-185^{\circ} \mathrm{C}\right)$ \\
\hline Density, Liquid @ $-301^{\circ} \mathrm{F} \quad$.. & $\ldots \ldots \ldots 0.68 \mathrm{~g} / \mathrm{ml}$ \\
\hline${ }^{\circ} \mathrm{C}, 1 \mathrm{~atm}$ & $\ldots \ldots \ldots \ldots 1.44 \mathrm{~g} / \mathrm{l}$ \\
\hline Viscosity, Gas @ $15^{\circ} \mathrm{C} \ldots$ & . 112.4 micropoise \\
\hline & $\left.4^{\circ} \mathrm{C}\right)$ \\
\hline sure $\ldots \ldots$ : & 702.7 psia \\
\hline Flammability Limits in Air & Spontaneously flammable \\
\hline 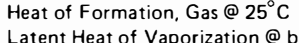 & $\ldots \ldots .7 .3 \mathrm{kcal} / \mathrm{mole}$ \\
\hline $\begin{array}{l}\text { Heat of Vaporization @ b } \\
\text { pacity, Gas @ } 25^{\circ} \mathrm{C} \text {, }\end{array}$ & \\
\hline
\end{tabular}
tions are easily reproduced.

\section{PHYSICAL PROPERTIES}

\section{PRODUCT SAFETY}

Specialty Gases include products with properties that can cause serious accidents, injuries, and even death if proper precautions and safety practices are not followed. Therefore, be certain to use all applicable safety precautions described in Specialty Gases Safety Precautions and Emergency Pro cedures, F-12-237, during storage, handling and use of these gases. F-12-237 is available on request from Union Carbide or from your Union Carbide Distributor. 


\section{Linde Division (Continued)}

\section{GAS REGULATION}

Union Carbide Silane Regulators Models SG-3862 and SG3865 are especially designed to handle silane and silane gas mixtures. Seat leakage caused by contamination from the reaction of silane with air is virtually eliminated. The valve stem (poppet) is attached to the diaphragm, forming single unit. If a seat leak occurs, the increasing delivery pressure will cause the stem to be pulled tighter and tighter against the seat until it seals off. This feature also permits the regulator to be used at very low inlet pressures.

Models SG.3862 and SG.3865 regulators have a stainles steel body, diaphragm, inlet filter and gauges, and outlet shut-off valve. Regulator and valve seat both are $\mathrm{Kel} \cdot \mathrm{F}$. A factory-installed purge assembly and a diffusion-resistant diaphragm seal shutoff valve on the outlet are standard.

Helium mass spectrometer leak detector tests of representative Models SG.3862 and SG.3865 regulators show an in board leakage rate of less than $1 \times 10^{-6} \mathrm{cc} / \mathrm{second}$. The regulators are available with either a 0 - to 15-psig or an 0 - to 75 -psig delivery pressure range as shown in the table below.

\begin{tabular}{ccc}
\hline $\begin{array}{c}\text { Inlet Pressure } \\
\text { Gauge } \\
\text { psig }\end{array}$ & $\begin{array}{c}\text { Delivery Pressure } \\
\text { Range } \\
\text { psig }\end{array}$ & Part No. \\
\hline $0-3000$ & $0-15$ & SG 3862.350 \\
$0-3000$ & $0-75$ & SG 3865.350
\end{tabular}

\section{TOXICITY}

The toxicity of silane is unknown. However, because of its combustion on contact with air yielding no known toxic by-products, the major hazard associated with silane is primarily from its spontaneous flammability with air.

Initially, the stigma of being pyrophoric caused a slow ac ceptance by industry of silane. However, it is now recognized as being no more hazardous if not even safer to handle than hydrogen. When a leak develops, it immediately burn with no release of known toxic fumes or buildup of an explosive atmosphere. The flame on burning is a relatively "cool" flame with no danger of melting metal tubing or "other assorted apparatus resuluing in some type of catastrophe. In many cases of small leaks, the resulung silica formed at the point of leakage seals itself. And in all cases, the fire is stopped by simply shutting off the cylinder valve to isolate the gas source.

MATERIALS OF CONSTRUCTION

Silane is non-corrosive to most metals. Piping and tubing can be of iron, brass, steel, stainless, or aluminum. However Type 316 stainless steel is recommended in plumbing of reactors and gas delivery systems. Stainless steel regulator should be used for all high purity applications with silane. All piping and tubing should be designed to withstand the pressures to be encountered. 


\section{Linde Division (Continued)}

\section{HANDLING AND STORAGE}

Silane and silane mixtures can be handled safely with the proper precautions to avoid contact with air at all times. Almost all recommendations are directed at not violating this one rule. Specific precautions that should be observed in handling silane are as follows:

1. Before using silane, read all equipment instructions, cylınder labels, data sheets, and other associated information pertaining to silane and its use.

2. Handle silane in a well-ventilated area while avoiding the presence of combustible materials.

3. Store silane at positive pressures

4. Do not condense silane $\left(-110^{\circ} \mathrm{C}\right.$ or less). Condensation of silane runs the risk of leaks developing with subsequent suck back of air into the system forming explosive mixtures.

5. Do not use silane in conjunction with heavy metal halides or free halogens which react violently. Care should be taken that all components of any silane handling system are purged of free halogens that might exist from degreasing agents or chlorinated hydrocarbons.

6. All systems to handle silane should be designed with these facts in mind:

a. Prevention of leakage, both in and out, under vacuum and pressure.

b. Minimum necessary internal volume

c. Elimination of dead spaces.

d. Isolation of system components in case of a leak, rupture, or other failure.

e. Ability to easily evacuate and purge the system and components with inert gas.

f. Silane should never be purged through a vacuum pump.

g. All fittings preferably should be of the welded type or Swagelok style to minimize the likelihood of leaks.

h. Use diaphragm packless valves with resilient seats such as Teflon.

i. Remove backplates from gauges and rotometers where gases may collect on leakage.

j. Use meta! diaphragm regulators to minimize air diffusion leakage.

7. All systems should be evacuated and thoroughly pressure checked for leaks at pressures two to three times the anticipated working pressure. In addition, a regular leak test procedure and testing schedule should be instituted and followed as part of normal preventive maintenance.

8. Ground all equipment and lines using silane.
9. An alternate vacuum and inert gas purge of the system should be used to purge all air out of the system after it has been leak checked.

10. When pressurizing the equipment with silane or a silane mixture, open the cylinder valve slowly. All other equipment adjustments of regulators, needle valves, etc., should also be made slowly.

11. Before disconnecting any system that has had silane in it, thoroughly purge the system of silane with an inert gas. Any portion of a system that is dead ended or allows "pocketing" of silane should be treated by considerable purging in the order of ten times the trapped volume.

12. Venting of silane or silane mixtures should be through small diameter pipe or tubing ending under a shallow water seal to prevent back diffusion of air. Venting should be to an area designed for silane disposal, preferably by burning. Concentrations even in the low percentage range are dangerous and should not be exposed directly to air except for disposal.

13. Do not store cylinders with oxidizers such as oxygen, chlorine, or flammable materials.

14. In addition, observe the following good cylinder practices in the handling and storage of silane:

a. Removable cylinder caps should be kept on cylin ders at all times until they arc secured against a wall, bench, or placed in a cylinder stand and are ready to use.

b. Never drop cylinders or permit them to strike each other violently.

c. Do not lift cylinders by the cap.

d. Avoid dragging, rolling, or sliding cylinders even for a short distance. They should be moved with a suitable hand truck

e. No part of any cylinder should be subjected to a temperature above $125^{\circ} \mathrm{F}$. A flame should never be permitted to come in contact with any part of a compressed gas cylinder

f. Cylinders should never be subjected to artificially created low temperatures.

g. Keep the cylinder valve closed at all times, except when the cylinder is in active use.

h. Never tamper with cylinder valves or attempt to repair or alter cylinders or valves.

Never use compressed gases where the cylinder is apt to be contaminated by the feedback of process materials, unless protected by suitabie traps or check valves

j. Notify the owner of the cylinder if any condition has occurred which might permit any foreign substance to enter the valve or cylinder, giving details and cylinder serial number.

k. Cylinders should be stored in an assigned area that is dry, cool, well ventilated, and fire resistant. 


\section{Linde Division (Concluded)}

HAND LING AND STORAGE (Continued)

Storage should comply with all local, state, and municipal regulations.

I. Cylinders stored in the open should be protected from extremes in weather and not exposed to continuous dampness or other corrosive conditions.

$m$. When returning empty cylinders, close the valve before shipment and leave some positive pressure in the cylinder. Replace all gas tight valve outlet cap and valve protective caps. Do not repaint, remove, or deface any cylinder markings, labels, decals, tags, and stencil markings used by the supplier for identification. Mark the contents label EMPTY.

DISPOSAL

Silane, silane mixtures, and silane purge or vent gases can readily be treated to destroy the silane by several means as follows

1. Burning the silane by slowly bleeding silane contairing gases into a continuously burning pilot flame.

2. By venting the silane containing gases slowly to the air through a water seal and burning by self ignition of the silane in an isolated area away from personnel.

3. Scrubbing the silane through a caustic bed or caustic solution ( $10 \%$ sodium hydroxide).

4. By reaction with aqueous mercuric chloride.

\section{UNION \\ CARBID \\ UNDE}

SPECIALTYGASES \&
RELAAED PAODUCTS

UNION CARBIDE CORPORATION • LINDE DIVISION

P.O. Box 444, 100 Davidson Avenue, Somerset, N.J. $08873 \bullet$ Telephone (201) 356-8000

TWX 710-997-9550 • TLX 833-199 available on request.

\section{AVAILABILITY AND SHIPPING DATA}

Pure silane is available in steel high.pressure cylinders of DOT 3AA2015 or 3AA2400 specification as follows:

\begin{tabular}{crccc}
$\begin{array}{c}\text { Cylinder } \\
\text { Size }\end{array}$ & $\begin{array}{c}\text { Grams } \\
\text { Silane }\end{array}$ & $\begin{array}{c}\text { Cylinder } \\
\text { Pressure } \\
\text { (psig) }\end{array}$ & $\begin{array}{c}\text { Cylinder } \\
\text { Dimensions }\end{array}$ & $\begin{array}{c}\text { Shipping } \\
\text { Weight }\end{array}$ \\
\hline T & 16000 & 1650 & $9 \times 55^{\prime \prime}$ & 180 lbs. \\
T & 10000 & 1250 & $9 \times 55^{\prime \prime}$ & 167 lbs. \\
T & 5000 & 730 & $9 \times 55^{\prime \prime}$ & 156 lbs. \\
K & 12000 & 1315 & $9 \times 52^{\prime \prime}$ & 161 lbs. \\
K & 5000 & 780 & $9 \times 52^{\prime \prime}$ & 146 lbs. \\
K & 1000 & 235 & $9 \times 52^{\prime \prime}$ & 137 lbs. \\
G & 600 & 625 & $6 \times 20^{\prime \prime}$ & 32 lbs. \\
G & 200 & 200 & $6 \times 20^{\prime \prime}$ & 31 lbs.
\end{tabular}

The cylinder valve is of a diaphragm, packless forged brass construction with safety devices. The valve outlet is of 350 CGA (Compressed Gas Association) design which has 825" -14 NGO left hand external threads and is bored to accept a $.5725^{\prime \prime}$ round nose nipple

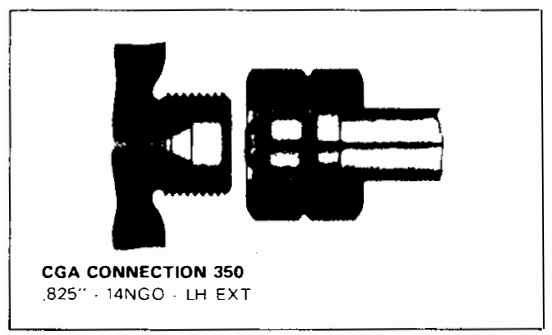

Silane is classified by the D.O.T. (Department of Transportation) as a flammable gas and carries a D.O.T. FLAM MABLE GAS shipping label. All silane cylinders are shipped with a gas tight cap on the valve outlet.

Silane is also available in gas mixture form with various background gases such as hydrogen, argon, nitrogen, and helium in varying concentrations. Additional information is 


\section{v. Liquid Carbonic,} Subsid. of Houston Natural Gas Corporation

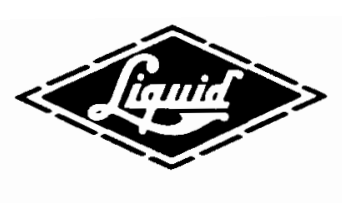

\section{LIQUID CARBONIC}

Subsidiary of Houston Natural Gas Corporation

\section{SPECIALTY GAS TECHNICAL SALES BULLETIN}

\section{SILANE SPECIFICATION \#SG-3}

Product

Physical State

Guaranteed Minimum Furtty

Typica1 Purity

Film Resistivity (1)

Epitaxial Grade

Polysilicon or Oxide Grade

Silicon Nitride Grade

Charge Couple Device Grade

HRS Crade

Typica1 Maximum Impurities (Gases)

Oxygen - ND

Total Hydrocarbons - $10 \mathrm{ppm}$

Water - ND

Carbon Monoxide/Carbon Dioxide - 10 ppm

Hydrogen - 500 ppm

Chlorosilanes (as choloride ion) - $10 \mathrm{ppm}$

Nitrogen - Less than 100 ppm

Trace Metals (3)

(1) Determined by four point probe method.

(2) Other quantities and cylinder sizes avallable on request.

(3) To be determined between supplier and customer.

Recommendation for Valve and Regulator - Valve CGA 350 Stainless Steel. Regulator - Liquid Carbon1c Model \#800S, 700S, Safety-T-Purge Module TDR\#440 or TDR $\$ 450$.

Revised \#6 - Feb. 1983

LCCOForm 2930 C
Silane

Gas, $\mathrm{SiH}_{4}$

$99.370 \%$

$99.99 \%$

$>100$ ohm-cm $\quad($ N-type $)$
$>50$ ohm-cm $" "$
$>50$ ohm-cm
$>200$ ohm-cm $" ~$
$>400$ ohm-cm

Net Contents Silane Available in Cylinders

1,000 Grams $\left(9^{\prime \prime} \times 52^{\prime \prime}\right)$

3,000 Grams (9" $\times$ X 52")

5,000 Grams ( $9 "$ " $\times$ 52")

14,000 Grams (9" x 55") 


\section{Matheson Division, Searle Medical Products USA Inc.}

\section{Disilane $-\mathrm{Si}_{2} \mathrm{H}_{6}$}

Background - Disilane, the dimer of $\mathrm{SiH}_{4}$, has recentiy received considerable attention. especially from research workers in amorphous silicon photovoltaics.

High deposition rates at low substrate temperatures make this new material a strong candidate for further studies in plasma an low pressurechemicalvapordeposition systems as a source of low pressurechemicalvapordycritline silicon.

Matheson is pleased to offer disilane from stock. Presently. 25 gram stainless steel cylinders are stocked in our Gloucester. Mass. branch. Other quantities are available upon request. The DOT-3E 1800 container and packless valve are sold outright. with a credit upon return.

Gas Properties - Typical Purity

$$
\begin{array}{ll}
\mathrm{Si}_{2} \mathrm{H}_{6} & 99+\% \\
\mathrm{H}_{2} & 0.15 \% \\
\mathrm{Si}_{x} \mathrm{H}_{y} \mathrm{Cl}_{2} & \text { less than } 100 \mathrm{ppm} \\
\mathrm{SiH}_{4} & 0.5 \%
\end{array}
$$

Disilane shows a slight tendency to decompose at room temperature with the production of hydrogen and silane.: Matheson's material is purified just prior to shipment actua $\mathrm{Si}_{\mathrm{i}}, \mathrm{H}_{\mathrm{r} ;}$ content is at least $25 \mathrm{grams}$ at time of shipment. Purity is a function of time and temperature.

Disilane is a flammable. pyrophoric gas. shipped as a liquid under its own vapor pressure of $32 \mathrm{psig}$ at $70^{\circ} \mathrm{F}, 21.1^{\circ} \mathrm{C}$ Calculated (approximate) vapor pressures are as follows:

$\begin{array}{cc}\text { Temp. C } & \text { Pressure, PSiA } \\ 0 & 20.8 \\ 10 & 34.3 \\ 20 & 45.5 \\ 25 & 53.2 \\ 30 & 60.9 \\ 40 & 78.3\end{array}$

Equipment - Maintenance of safety and purity is important. Because disitane is a liquid in thecylinder. it should not be plac. ed horizontally during use. Matheson offers an appropriate cylinder stand. regulator and purge combination which minimizes interior volume and package weight while it max. imizessafety. purity and ease of use.

Matheson's 3455 regulator and 1423-SP cross purge assemblyand Model 505 cylinder stand provide the user with a proven design, maintaining high puritywith minimal loss of gas during purging

1) Scott,B. A et ai. Glow Discharge Preparation of Amorphous Hydrogenated Silicon from Higher Silanes. App. Phys Letter 37, 1980 - pg. 725-727

2) Wiberg. E. \& Amberger. E. Hydrides of the Elements of Main Groups I-IV: Elsevier Publishing Co. 1971

3) Harper. L.R.. Yolies. \& Miller, H.C. - Decomposition of Disilane. Separation of Silane/Disilane Mixtures by Gas.

\begin{tabular}{|c|c|c|c|c|c|}
\hline 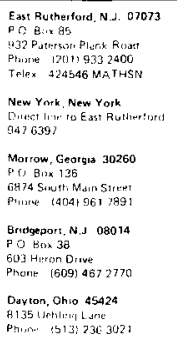 & 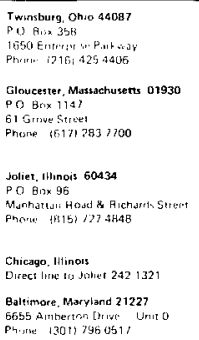 & 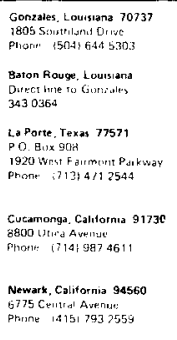 & 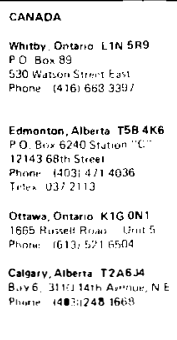 & 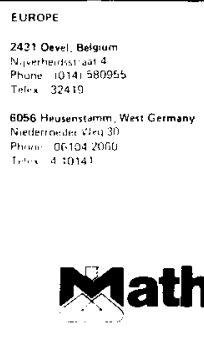 & 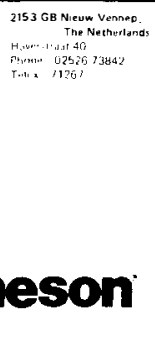 \\
\hline
\end{tabular}
Phase Chromotography. J.Inorg. Nucl Chem.. 1961, Vol 21. pg. 294-296

4) Wiberg \& Amberger. Ref. 2 
VI. Katheson Division (Concluded)

\section{Matheson \\ TECLH/Brief}

\section{MATHESON PURITY SILANE 1000 ohm-cm}

Matheson has responded to revolutionary changes in purity requirements for semiconductor process ing with a new grade of silane. This new material is purer by orders of magnitude than normal, commercially available silane.

The new Matheson Purity Silane costs more, but is clearly economical when yield improvements are attributed to its use. Maximum cost-effectiveness is noted in critical epitaxial and poly-silicon deposi tions. Nitride and critical oxide depositions also benefit from reduced defect densities caused by particulates and volatile impurities.

Purification to remove active dopants has resulted in silane with a resistivity of $1000 \mathrm{ohm}-\mathrm{cm}$. This effectively reduces most metallic and reactive im purities to limits imposed by cylinder preparation. Analysis of process stream silane for these impurities before compression into cylinders would be of no value. Matheson's proprietary cylinder treat ment techniques assure that the container contri bution is minimal.

The true test of Matheson Purity Silane lies in your end-use results ... yield increases, better process control, low leakage, higher lifeiime, fewer stacking faults are just some of the potential gains that can be realized with this inaterial.

Matheson Purity Silane is available in cylinders containing $12,000,5,000$ and 1,200 grams net contents.

\begin{tabular}{|c|c|c|c|c|c|}
\hline 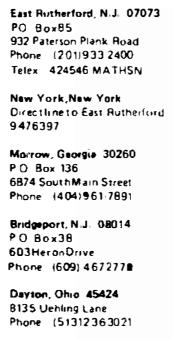 & 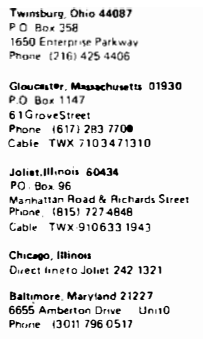 & 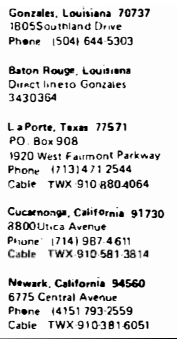 & 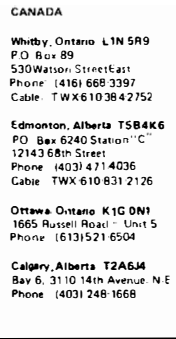 & 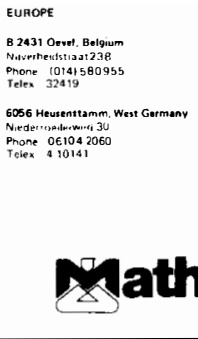 & 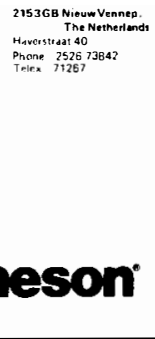 \\
\hline
\end{tabular}


VII. Scientific Gas Products, Inc.

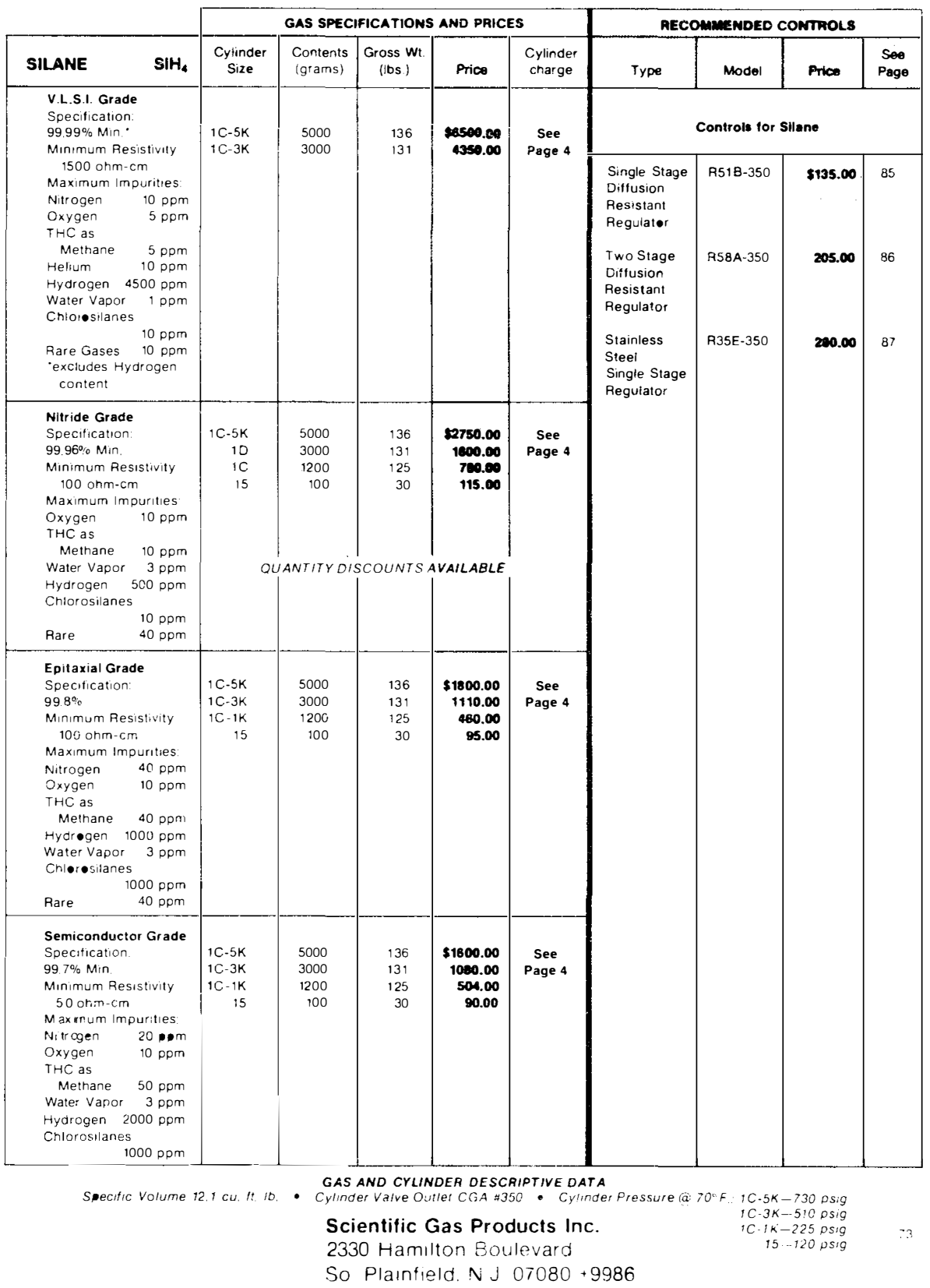




\section{Synthatron Corporation}

SYNTHATRON CORPORATION

50 INTERVALE ROAD

PARSIPPANY, NEW JERSEY O7054

March 8, 1983

TEL. 201.335 .5000

TLX 136454

Mr. J. H. Lorenz

Dear Mr. Lorenz:

I am writing you this letter in response to the survey form on silane and Disilane which you forwarded to us on February 25.

1. Synthatron manufactures and sells both mono-Silane and Disilane. As you might understand, we consider our manufacturing and purification processes proprietary, as do most people in the specialty gas business.

2. We make silane available at various purity levels. The best Silane we sell currently can be characterized by the following typical analyses:

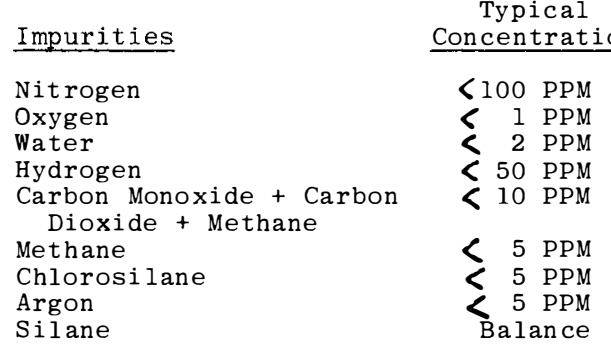

The impurity profile of a typical lot of Synthatron Disilane would be as follows:

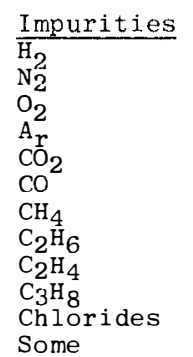

$$
\begin{aligned}
& 0.5-1.6 \% \\
& <50 \text { PPM } \\
& <50 \\
& <50 \\
& <20 \\
& <50 \\
& <10 \\
& <11 \\
& <1 \\
& <1 \\
& .5 \% \\
& 99.0 \% \text { pure }
\end{aligned}
$$




\section{Synthatron Corporation (Continued)}

Mr. J. H. Lorenz

Page 2

March 8, 1983

3. Most of our impurity analyses are performed by gas chromatography and a complete analysis for each of the listed impurities is available on an individual cylinder basis for $\$ 125.00$.

4. Synthatron holds a voting membership on all of the relevant SEMI committees. We have approved and voted for the SEMI Silane standards and have contributed our in-put to their development. Naturally, we are prepared to analyze our material to insure its compliance with these standards.

5. Because of the hazardous nature of Silane, we do our best to discourase our customers' running their own purification procosses, nn the material. If, however, a specific impurity is of particular concern to a customer, we can give him advice concerning purification for that specific impurity on an ad hoc basis.

6. I have enclosed data sheets on the Silane currently available from Synthatron. Together with the typical analysis listed above, that should give you a comprehensive view of the materials we make available. Pricing on this material is contengent on total volume and quantity per package. In general terms, it can be said that the price will range between $\$ .19$ per gram and $\$ .55$ per gram. The cylinder sizes available from our company expressed in their volumetric capacities, expressed in liters of water, are as follows: 0.44 liters (lecture bottle), 3.7 liters (No. 3 ), 6.9 liters (No. 7), 16.7 liters (No. 16), 43.8 liters (No. 44), and 49.0 1 iters ( No. 49).

Should you have any further questions concerning Synthatron's Silane or Disilane, please call me at your convenience.

Yours truly,

SYNTHATRON CORPORATION

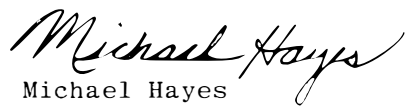

National Sales Manager

$\mathrm{MH} / \mathrm{ss}$

Encl. 
VIII. Synthatron Corporation (Concluded)

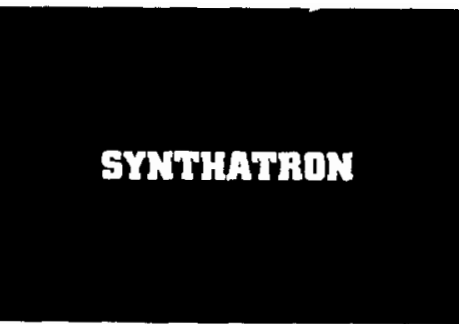

SYNTHATRON CORPORATION

\section{SILANE \\ SPECIFICATIONS}

201-335-5000 TLX 136454

50 INTERVALE ROAD, PARSIPPANY, N.J. 07054

SE M I-GRADE

(IMPURITIES IN PPM)

IMPURITY

oxygen $\left(\mathrm{O}_{2}\right)$

water $\left(\mathrm{H}_{2} \mathrm{O}\right)$

Hydrogen $\left(\mathrm{H}_{2}\right)$

Carbon Dioxide

and Carbon Monoxide

$\left(\mathrm{CO}_{2}+\mathrm{CO}\right)$

Total Hydrocarbons

*Chlorosilane

Rare Gases

EPITAXIAL

NITRIDE

POLYSILICON

10

10

3

3

10,000

10,000

500

Nitrogen

$\star \star$ Resistivity

$50 \mathrm{ohm}-\mathrm{cm}$

$100 \mathrm{ohm}-\mathrm{cm} 50 \mathrm{ohm}-\mathrm{cm}$

* Ionizable chlorides including $\mathrm{HCL}$ reported as $\mathrm{Cl}$.

** Greater than, n-type. 


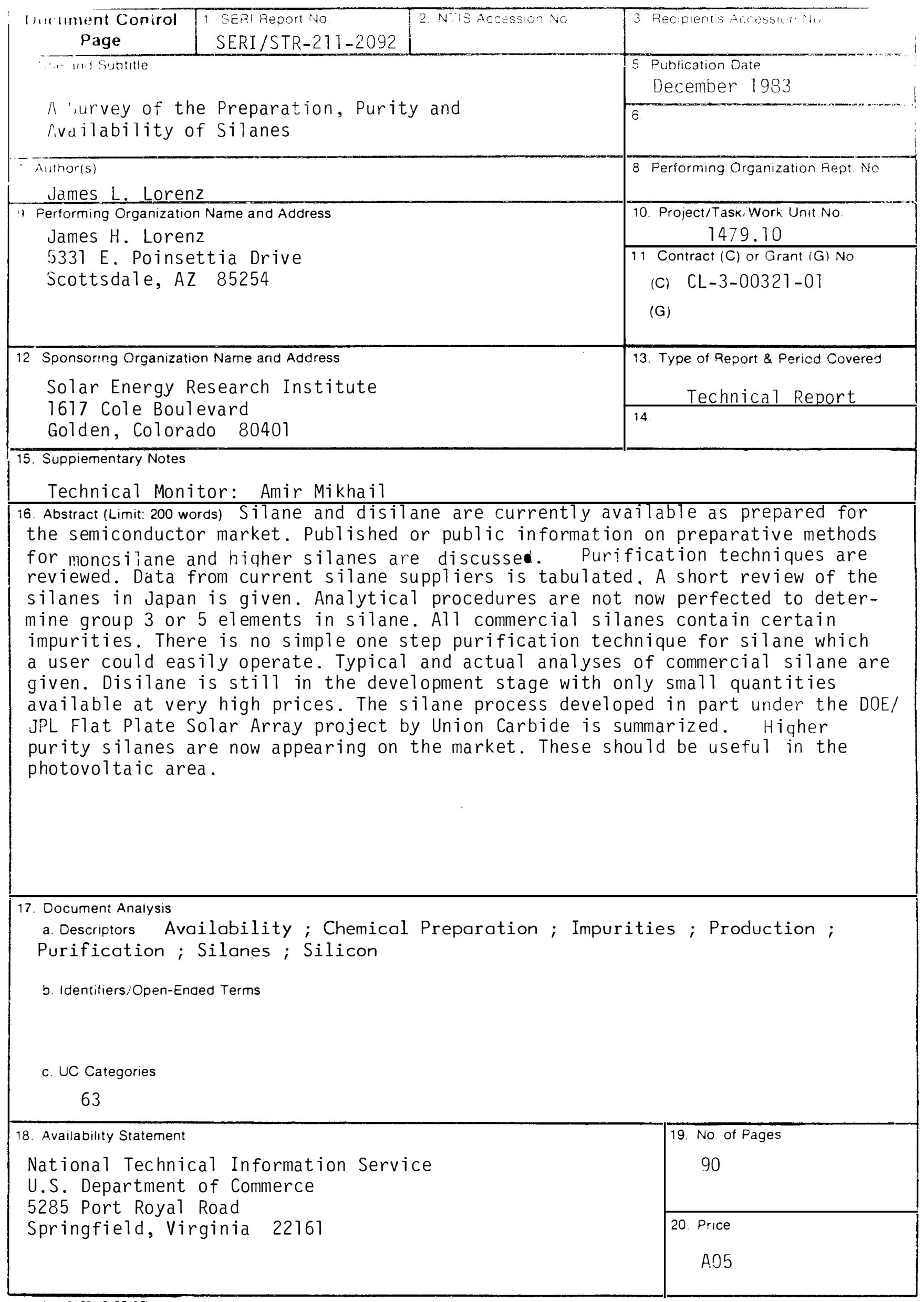

